\title{
Nutrient content of school lunches and packed lunches as consumed by elementary school students
}

\author{
Pamela Cheryl Hamilton \\ West Virginia University
}

Follow this and additional works at: https://researchrepository.wvu.edu/etd

\section{Recommended Citation}

Hamilton, Pamela Cheryl, "Nutrient content of school lunches and packed lunches as consumed by elementary school students" (2001). Graduate Theses, Dissertations, and Problem Reports. 1249. https://researchrepository.wvu.edu/etd/1249

This Thesis is protected by copyright and/or related rights. It has been brought to you by the The Research Repository @ WVU with permission from the rights-holder(s). You are free to use this Thesis in any way that is permitted by the copyright and related rights legislation that applies to your use. For other uses you must obtain permission from the rights-holder(s) directly, unless additional rights are indicated by a Creative Commons license in the record and/ or on the work itself. This Thesis has been accepted for inclusion in WVU Graduate Theses, Dissertations, and Problem Reports collection by an authorized administrator of The Research Repository @ WVU. For more information, please contact researchrepository@mail.wvu.edu. 
NUTRIENT CONTENT OF SCHOOL LUNCHES AND PACKED LUNCHES AS

CONSUMED BY ELEMENTARY SCHOOL STUDENTS

\author{
Pamela C. Hamilton
}

Thesis submitted to the

College of Agriculture, Forestry and Consumer Sciences

at

West Virginia University

in partial fulfillment of the requirements

for the degree of

\author{
Master of Science \\ in \\ Human Nutrition and Foods
}

M. Zafar Nomani, Ph.D., R.D., L.D., Chair

Carol Markstrom, Ph.D.

Betty Forbes, M.A., R.D., L.D.

Cindy Fitch, Ph.D., R.D., L.D.

Division of Family \& Consumer Sciences

Morgantown, West Virginia

2001

Keywords: Child Nutrition, Recommended Dietary Allowances (RDA),

Dietary Reference Intakes (DRI), Dietary Guidelines

Copyright 2001 Pamela C. Hamilton 


\section{ABSTRACT \\ Nutrient Content of School Lunches and Packed Lunches as Consumed by Elementary School Students}

\section{Pamela C. Hamilton}

This study compared nutrient content and intake of school and home-packed lunches. Food intake was estimated by weighing all food items and leftovers of 114 elementary school children. Eighty-one percent of subjects consumed school lunch and nineteen percent consumed packed lunches. A nutrient analysis was conducted using Nutritionist V. Significant differences between the two types of lunch were determined using ANOVA and Tukeys Test (HSD.UEN), $\mathrm{p}<0.05$.

School lunches as selected were nutritionally superior to packed lunches for protein, vitamin $\mathrm{A}$, vitamin $\mathrm{D}$, riboflavin, vitamin $\mathrm{B}_{6}$, folate, vitamin $\mathrm{B}_{12}$, pantothenic acid, calcium, phosphorus, magnesium, zinc, and dietary fiber at $\mathrm{p}<0.05$.

After considering food waste, nutrient intake from school lunch remained significantly higher $(\mathrm{p}<0.01)$ for vitamin $\mathrm{D}$, vitamin $\mathrm{B}_{12}$, pantothenic acid, phosphorus, magnesium, and zinc; $(\mathrm{p}<0.05)$ for riboflavin, vitamin $\mathrm{B}_{6}$, folate, and calcium.

It was also noted that intake of milk and other dairy foods was higher $(\mathrm{p}<0.01)$ from school lunches.

Nutrient content of school lunch in this study was adequate based on federal and state guidelines for most nutrients and fiber, however, improvement is needed in overall nutrient intake from school lunch. Packed lunches were inferior to school lunches in both nutrient content and intake. Further, the findings suggest that milk and other dairy foods that are naturally high in calcium and nutrient-dense overall would significantly improve the nutritional status of packed lunches. 


\section{ACKNOWLEDGEMENTS}

I would like to extend my sincere appreciation to Dr. M. Zafar A. Nomani, advisor and chair of my thesis committee, for the hours of assistance in data analysis that he has provided. In addition, I wish to acknowledge Dr. Carol Markstrom, Mrs. Betty Forbes, and Dr. Cindy Fitch for their time, patience, and professional guidance provided as members of my committee.

To my husband, Delane and my children, Dane and Lauren, who have patiently endured the rigors of this research, I extend my love and appreciation.

To my mother-in-law, Mary Hamilton, and my sister, Carolyn Bainbridge, I extend my deepest gratitude for being there for my children when I was not able to be.

To Judith Radcliff, a valued mentor and friend, I extend my appreciation for valuable professional support and opportunities she has provided me.

To Karen S. Hawkins, Child Nutrition Program Director for Marion County Schools, I express my special thanks for her time and effort on behalf of this research.

To Sharon Yanero, former student, coworker, and friend, I extend great appreciation for her assistance in data collection. 


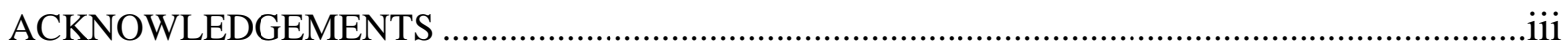

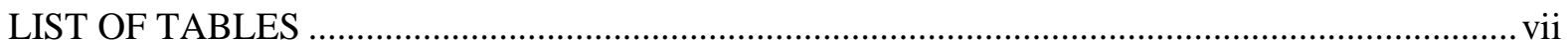

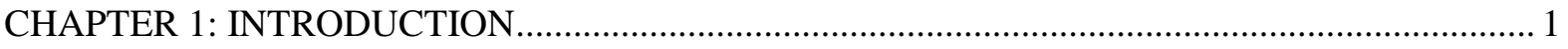

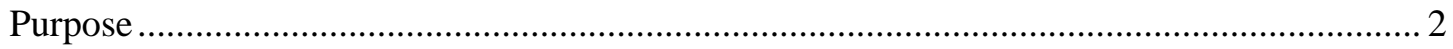

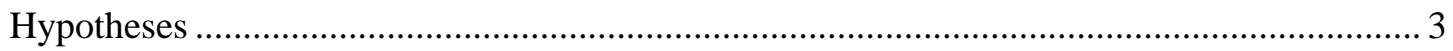

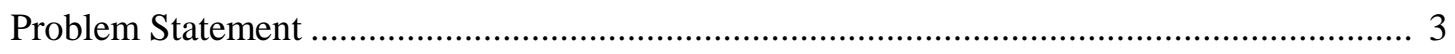

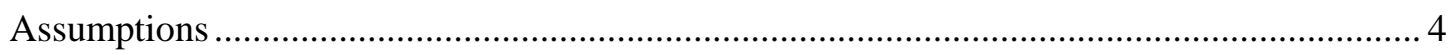

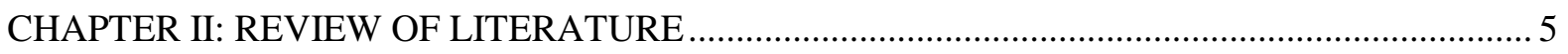

Importance of Healthy Food Choices By Children ............................................................ 5

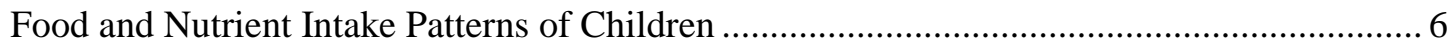

Standards and Goals for Nutritional Adequacy in Children ............................................... 7

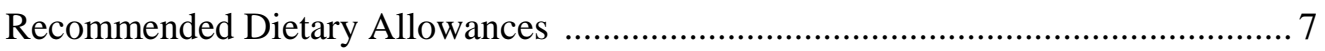

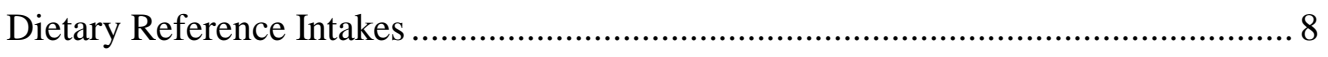

Food Guide Pyramid: A Guide to Daily Food Choices ........................................... 10

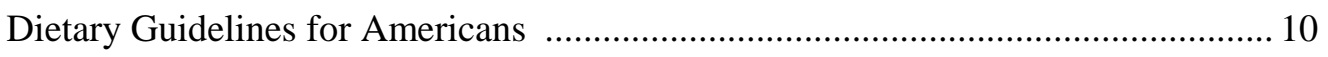

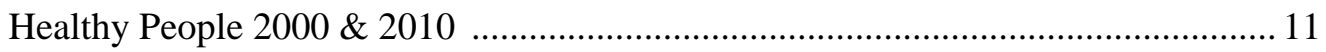

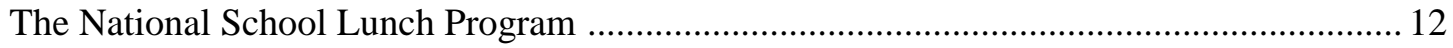

Standards for the National School Lunch Program ............................................... 12

Nutrient Contributions of School Lunch ................................................................. 14

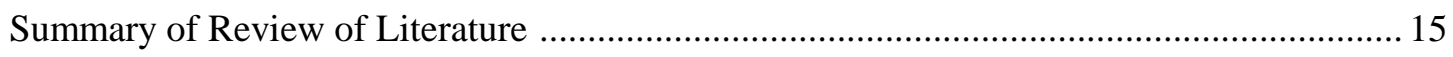

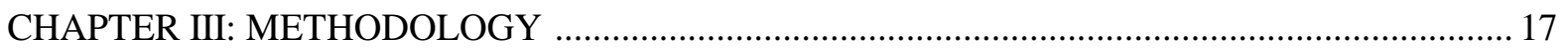

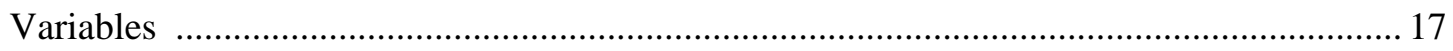

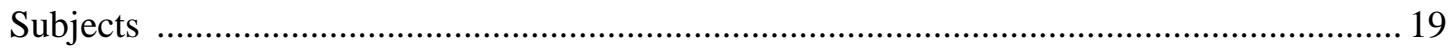


Sample Selection

Procedures

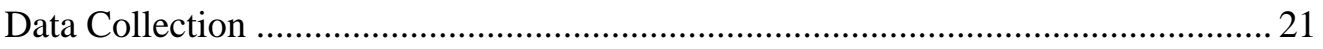

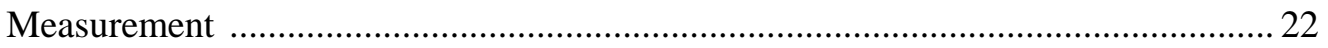

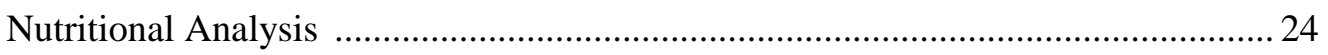

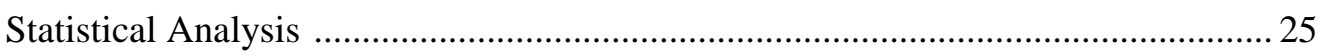

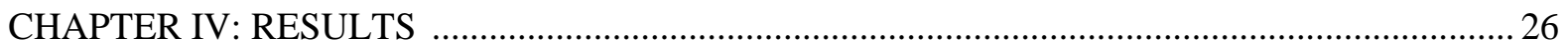

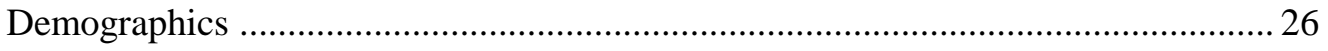

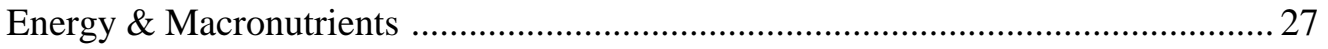

Nutrients \& Fiber Related to USDA/WVBOE Standards ...................................... 32

Nutrients Related to Osteoporosis and other Bone-related Diseases ....................... 35

Nutrients Associated with Cancer Prevention .................................................... 38

Nutrients Acting as Facilitators for Energy Release \& Prevention of .................... 40 Developmental Disorders

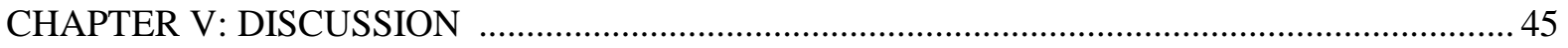

Comparison of Overall Nutrient Content and Intake Between School and Packed Lunches 45

Comparison of Nutrient Categories Among School and Packed Lunches ............................ 46

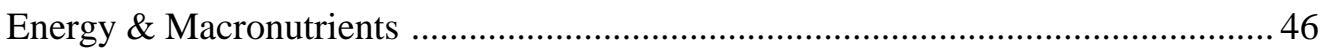

Nutrients \& Fiber Related to USDA/WVBOE Standards ................................... 47

Nutrients Related to Osteoporosis and other Bone Integrity ................................ 49

Nutrients Associated with Cancer Prevention .........................................................50

Nutrients Acting as Facilitators for Energy Release \& Prevention of ......................50 Developmental Disorders

Nutrient Value of School and Packed Lunches as Compared to National and State ............. 51 School Lunch Standards

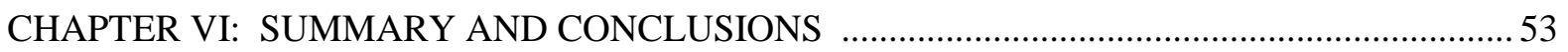

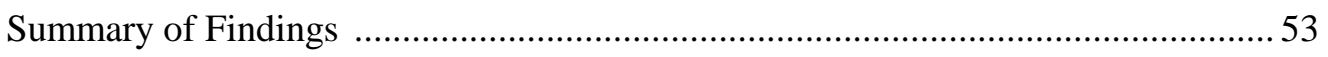


Implications and Applications for Further Research

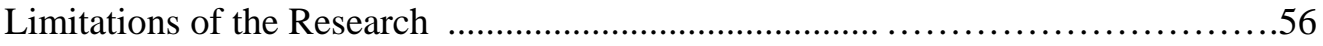

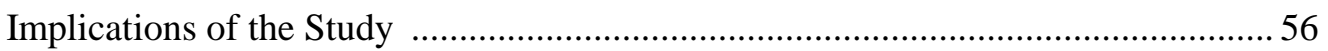

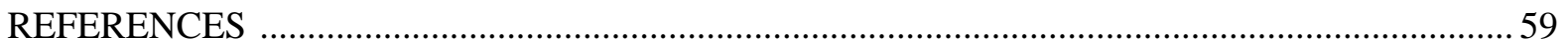

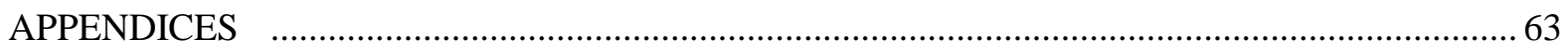

Appendix A: Approval Letters from Participating Schools ............................................... 64

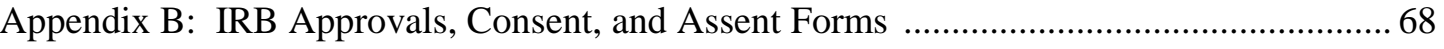

Appendix C: Data Collection Form and Letter of Permission from Former Study ............... 78

Appendix D: Sample Calculation for Combination Sandwich or Dish from Home .............. 81

Appendix E: County Menu, Production Records, Recipes, and Menus Items as Entered..... 83 In Nutritionist $\mathrm{V}$ 


\section{LIST OF TABLES}

TABLE 1: Dietary Guidelines for Americans, 1995-2000 ………….....................................10

TABLE 2: Healthy People 2010: Nutrition and Overweight Objectives ..............................12

TABLE 3: Nutrient Standards for Comparison of School and Packed Lunches ....................18

TABLE 4: Student Distribution Among Three Participating Schools ...................................21

TABLE 5: Date and Distribution of Data Collection for Subjects ........................................23

TABLE 6: Descriptive Analysis of the Number and Percent of Participants ........................27

TABLE 7: Energy Content and Intake of Student Lunches From School or Home ……......29

TABLE 8: Protein Content and Intake of Student Lunches From School or Home ……......29

TABLE 9: Carbohydrate Energy Content and Intake of Student Lunches From ....................30 School or Home

TABLE 10: Content and Intake of Energy From Fat in Student Lunches From School ........30 Or Home

TABLE 11: Content and Intake of Energy From Saturated Fat in Student Lunches 31 From School or Home

TABLE 12: Content and Intake of Energy from Sugar in Student Lunches From .31 School or Home

TABLE 13: Sodium Content and Intake of Student Lunches From School or Home .33

TABLE 14: Dietary Fiber Content and Intake of Student Lunches From School or Home ..33

TABLE 15: Iron Content and Intake of Student Lunches From School or Home .34

TABLE 16: Vitamin A Content and Intake of Student Lunches From School or Home ......34

TABLE 17: Zinc Content and Intake of Student Lunches From School or Home ................35

TABLE 18: Calcium Content and Intake of Student Lunches From School or Home ...........36

TABLE 19: Phosphorus Content and Intake of Student Lunches From School or Home .....36 
TABLE 20: Magnesium Content and Intake of Student Lunches From School or Home .....37

TABLE 21: Vitamin D Content and Intake of Student Lunches From School or Home .....37

TABLE 22: Fluoride Content and Intake of Student Lunches From School or Home ..........38

TABLE 23: Vitamin C Content and Intake of Student Lunches From School or Home .......39

TABLE 24: Vitamin E Content and Intake of Student Lunches From School or Home .......39

TABLE 25: Thiamin Content and Intake of Student Lunches From School or Home ..........41

TABLE 26: Riboflavin Content and Intake of Student Lunches From School or Home ......41

TABLE 27: Niacin Content and Intake of Student Lunches From School or Home .............42

TABLE 28: Vitamin $B_{6}$ Content and Intake of Student Lunches From School or Home .....42

TABLE 29: Folate Content and Intake of Student Lunches From School or Home .............43

TABLE 30: Vitamin $B_{12}$ Content and Intake of Student Lunches From School or Home ....43

TABLE 31: Pantothenic Acid Content and Intake of Student Lunches From School ...........44 Or Home

TABLE 32: Biotin Content and Intake of Student Lunches From School or Home .44 


\section{CHAPTER I}

\section{INTRODUCTION}

The eating patterns of Americans have changed significantly over the past twenty years. It has been established that an unhealthy diet is a known risk factor for the development of the nation's four leading causes of death: coronary heart disease (CHD), certain types of cancer, stroke, and type 2 diabetes (National Center for Health Statistics, 1995). According to Kelder, Perry, Klepp and Lytle (1994), the unhealthy eating and activity patterns that contribute to adult diseases such as these, often begin in childhood and are maintained through habit into adulthood. Other diet-related health problems that occur in adulthood but may have their onset in childhood include high blood pressure, osteoporosis and the condition of being overweight. The U.S. Department of Health and Human Services (Public Health Service, 1998) reports that the prevalence of being overweight among Americans has increased since 1980 for nearly all age, ethnic, and gender groups.

West Virginia leads the nation in many diet-related adult diseases. In 1997, West Virginia was ranked number one for prevalence of obesity among the fifty states, the District of Columbia, and Puerto Rico (West Virginia Department of Health and Human Resources, 1999). In the same year, three of the ten leading causes of death for West Virginia residents resulted from diet-related diseases. These included cancer, heart disease, and cerebrovascular diseases (West Virginia Department of Health and Human Resources, 1999).

The development of a healthy lifestyle begins in childhood and includes the ability to make wise food choices. Federal nutrition policy (HR 2066: the Healthy Meals for Healthy Children Act as of 1993) mandated that school lunches should provide one-third of the Recommended Dietary Allowances (RDAs) (National Academy of Science, 1989) for energy, 
protein, calcium, iron, vitamin A and vitamin C. This same policy required that by no later than school year 1998-99, the 1990 Dietary Guidelines must be implemented into school lunch programs (Martin, 1996). The West Virginia Board of Education extended this standard with new legislation ( $\delta 126-86-4321.1)$ enacted in 1993 and completely implemented by the 1995-96 school year, requiring that all school lunches provide six grams of naturally occurring dietary fiber, no more than 1,100 milligrams (mg) sodium, no more than $30 \%$ of calories from fat and $10 \%$ of calories from saturated fat (West Virginia Board of Education, 1994).

Consider whether current school lunches within the state are meeting these requirements. How do lunches brought from home compare to school lunches based on the standards set by these recommendations for children? This study will attempt to evaluate the content of school lunches as selected by elementary students in West Virginia and packed lunches provided from home, by comparing their nutrient value.

\section{Purpose:}

The primary objective of this research is to compare the nutritional value of school lunch (food items offered by school food service personnel including a choice of up to five school lunch components, but not less than three of the five offerings) and packed lunch (food and/or beverages brought from home). A secondary objective will be to determine if student lunches as selected and consumed meet the most current nutrient standards (DRI, RDA, and Dietary Guidelines for Americans) for children ages 7-10 years. The overall purpose of the study will be to make the results of this data available to parents and teachers in order to evaluate the nutrient adequacy of food selections made by children in this age 
group. In order to achieve the objectives of this study, the following hypotheses will be tested:

\section{Hypothesis 1:}

There is no difference in the nutrient content of school lunches and packed lunches.

\section{Hypothesis 2:}

There is no difference in the nutrient intake of school lunches and packed lunches as consumed.

\section{Hypothesis 3:}

There is no difference between school lunches and packed lunches in relation to latest RDA, DRI, and the Dietary Guidelines for Americans.

\section{Problem Statement}

The eating patterns of children have changed dramatically over the past years as a result of changes in lifestyle, foods available for consumption and advertising. In addition, health initiatives for American children have shifted from concerns of too little food to those of overconsumption. It is known that diet and exercise trends in childhood have significant bearing on adult health status and tendencies towards diet-related diseases (Munoz, KrebsSmith, Ballard-Barbash, \& Cleveland, 1997). Food choices that parents determine for their children and those that children choose themselves are often influenced more by advertising and peers than by sound nutrition knowledge. Comparing school lunches, which are required to comply with set standards, to packed lunches may provide data that will assist with nutrition education for children, parents, and teachers. 


\section{$\underline{\text { Assumptions }}$}

The methodology of this study is based on the following basic assumptions:

1. There have been no changes made in the students' typical packed lunches as a result of parental/guardian consent to participate in the study, nor in the students' consumption of the packed lunch as a result of agreement to participate in the study.

2. There have been no changes in the typical school lunch as prepared and portioned by school food service personnel, nor of student selection and consumption of the school lunch as a result of agreement to participate in the study. 


\section{CHAPTER II}

\section{REVIEW OF LITERATURE}

\section{Importance of Healthy Food Choices By Children}

Current literature strongly indicates that the eating patterns of Americans have changed dramatically over the past two decades (Wotecki, 1992). Kennedy \& Goldberg (1995), noted that children are eating more frequently, consuming a larger percentage of nutrients from snack foods, and eating larger numbers of meals away from home. It has been established that diet is a known risk factor for the development of the nation's four leading causes of death: coronary heart disease (CHD), some types of cancer, stroke, and type 2 diabetes (National Center for Health Statistics, 1995). According to Kelder, Perry, Klepp and Lytle (1994), the unhealthy eating and activity patterns that contribute to adult diseases such as these, often begin in childhood and are maintained through habit into adulthood. Other diet-related health problems that occur in adulthood, but may have their onset in childhood, are high blood pressure, osteoporosis and the condition of being overweight. The Department of Health and Human Services (Public Health Service, 1998) reports that the prevalence of overweight has increased since 1980 for nearly all age, ethnic and gender groups. The condition of being overweight increases the risk for development of long-term health problems such as Type II diabetes, coronary heart disease, cancer, stroke, and osteoporosis. Power, Lake, and Cole (1997), indicated that adult mortality and morbidity are influenced by childhood adiposity. 


\section{Food and Nutrient Intake Patterns of Children}

The 1999 U.S. Department of Agriculture report on the most recent Continuing Survey of Food Intakes by Individuals (CSFII 1994-1996) indicated that the decline in diet quality normally occurs between the ages of two to three and four to six. The percentage of children who have a good diet at these ages falls from $35 \%$ to $16 \%$. These are the ages when children begin to make food choices based on the eating patterns of other family members, their environment, and advertising. According to Birch (1999), many food choices most readily available to this age group include energy-dense foods that are high in sugar, fat, and salt. She also indicated that these trends provide eating environments that foster food preferences inconsistent with dietary guidelines and promote excess weight gain and obesity. Another trend in the food industry is vitamin and mineral fortification of many snack foods and high-sugar beverages. This practice misleads many consumers into believing that they are providing a sound source of nutrition for their children.

The 1997 Youth Risk Behavior Surveillance System (YRBSS) representing ninth through twelfth grade students nationwide indicated that less than one-third of the students had eaten five or more servings of fruits and vegetables, but more than one-half of the students had eaten two or fewer servings of foods high in fat. In the same year, state-level Youth Risk Behavior Surveillance System data indicated that the median prevalence of eating five or more servings of fruits and vegetables a day is $27.0 \%$. West Virginia fell below the median with a lower prevalence of $24.5 \%$. The state median for prevalence of eating two or fewer servings of high-fat foods a day is $61.8 \%$. Data for West Virginia indicated that $59.2 \%$ of the state's representative sample ate two or fewer servings of high-fat foods (Centers for Disease Control and Prevention, 1997). 
The Bogalusa Heart Study which tracked dietary intake of children in a biracial community indicated an overall decline in the total amount of milk, vegetables, soups, breads, grains, and eggs consumed with an increase in total amounts of fruits and fruit juices, carbonated beverages, poultry, and cheese consumed (Nicklas, 1995). Between 1977 and 1994, milk consumption for both boys and girls had declined with a higher percentage of dietary fat being obtained from cheese, poultry, and snack foods (Borrud, Enns, \& Mickle, 1997).

Results from the Child and Adolescent Trial for Cardiovascular Health (CATCH) Baseline Survey (Osganian et al., 1995) indicated that most children living in the United States did not meet recommended food intakes as outlined by the Food Guide Pyramid (U.S. Department of Agriculture/U.S. Department of Health \& Human Services, 1995).

\section{$\underline{\text { Standards and Goals for Nutritional Adequacy in Children }}$}

\section{Recommended Dietary Allowances. Recommended Dietary Allowances}

(RDAs) are the levels of intake of essential nutrients that, on the basis of scientific knowledge, are judged by the Food and Nutrition Board to be adequate to meet the known nutrient needs of practically all healthy individuals. RDAs are given for energy, protein, vitamin A, vitamin E, vitamin $\mathrm{K}$, vitamin $\mathrm{C}$, iron, zinc, iodine, selenium, thiamin, riboflavin, niacin, vitamin $\mathrm{B}_{6}$, vitamin $\mathrm{B}_{12}$, folate, phosphorus, magnesium, iron, zinc, iodine, and selenium. Adequate Intakes (AI) are also given for vitamin D, pantothenic acid, biotin, choline, calcium, and fluoride. The RDA are neither minimal requirements nor necessarily optimal levels of intake. They are most appropriately applied to groups, however comparison of individual intake, averaged over time, to the RDA allows estimation to be made regarding 
probable deficiency risks for individuals (National Research Council, 1989). Safe and adequate intakes are given in ranges for copper, manganese, fluoride, chromium, and molybdenum. Sodium, potassium, and chloride are given as estimated minimum requirements.

Dietary Reference Intakes. The Dietary Reference Intakes (DRIs) are nutrient-based values for use in planning and assessing diets for individuals as well as groups. The DRIs reflect a shift in emphasis from preventing deficiency to decreasing the risk of diet-related chronic conditions such as heart disease, diabetes, hypertension, and osteoporosis (International Food Information Council, 1998). DRIs include the following nutrient requirement values: the RDA (Recommended Dietary Allowances), EAR (Estimated Average Requirement), AI (Adequate Intake), and UL (Tolerable Upper Level). Using these four values, expert panels have worked and continue to work to customize nutrient standards that address nutrient adequacy while maintaining nutritional integrity (Barrett, 1997). Three complete reports on the Dietary Reference Intakes published by the Food and Nutrition Board are now available. The first report (Institute of Medicine, 1997) addresses the DRIs for calcium, phosphorus, magnesium, vitamin D and fluoride. Emphasis is on the importance of these nutrients in prevention of bone-related diseases and disorders. Bryant, Codogan, \& Weaver (1999), noted that calcium intake, which affects calcium retention in the bones and determines bone mass and skeletal fragility, falls short of recently established requirements. The calcium requirements in childhood and adolescence are determined by the high rate of bone mineral growth that occurs at this stage of development and is critical to adult bone status. Calcium's role in reducing the risks of such chronic diseases as colon cancer and 
hypertension have been considered in recent studies, but calcium deficiency and it link to osteoporosis have received the most attention.

The second DRI report refers to intakes for thiamin, riboflavin, niacin, vitamin $\mathrm{B}_{6}$, folate, vitamin $\mathrm{B}_{12}$, pantothenic acid, biotin, and choline and considers evidence regarding prevention of disease and developmental disorders along with traditional evidence of sufficient nutrient intake (Institute of Medicine, 1998). As noted by Sizer and Whitney (2000), deficiencies of any of the B vitamins are critical to cell renewal because they facilitate the body's use of the energy nutrients. During periods of growth and development, limitations in these nutrients may cause damage in which full recovery may be impossible.

The "dietary antioxidants" (vitamin C, vitamin E, selenium, and carotenoids), evidence regarding their impact on chronic disease, and their roles in relation to deficiency states are addressed in the most recently published DRI report (Institute of Medicine, 2000). Monsen, (2000), highlighted six key points in relationship to the report. Food, rather than supplements was indicated as a preferred source of the dietary antioxidants because of the multiple nutrient value provided by food.

The fourth DRI report, recently released for publication during the completion of this research study and discussed by Trumbo, Schlicker, \& Poos, (2001) addresses intake standards for vitamin A, vitamin K, arsenic, boron, chromium, copper, iodine, iron, manganese, molybdenum, nickel, silicon, vanadium, and zinc. According to the commentary by these authors, specific criteria for adequacy were used to determine estimated requirements. For example, in determination of iron requirements, the committee chose to set criteria at the level to maintain minimal iron stores rather than the lower values needed to prevent anemia. 


\section{Food Guide Pyramid: A Guide To Daily Food Choices. The Food Guide Pyramid}

(U.S. Department of Agriculture \& U.S. Department of Health \& Human Services, 1995) is a visual representation of the Daily Food Guide and works as an excellent teaching tool to illustrate the importance of balance among food groups in a daily eating pattern.

Dietary Guidelines for Americans. Every five years, the USDA and USDHHS publish a set of guidelines that are representative of the best current advise of nutrition scientists. Table 1 lists the 1995 and 2000 Dietary Guidelines for Americans. These guidelines are recommended for persons above the age of two years to prevent certain diseases and promote good health throughout life. The 1995 Dietary Guidelines served as a useful tool to assist the nation in its efforts to achieve the Healthy People 2000 objectives (Public Health Service: U.S. Department of Health \& Human Services, 1991). Variances between the updated guidelines and the former 1995 guidelines represent recommendations of the Dietary Guidelines Advisory Committee to help Americans make sensible choices that promote health and reduce chronic disease risks.

Table 1. USDA and USDHHS. Dietary Guidelines for Americans, 1995-2000.

\section{Dietary Guidelines For Americans, 1995}

- Balance the food you eat with physical activity maintain or improve your weight.

- $\quad$ Eat a variety of foods.

- Choose a diet with plenty of grain products, vegetables and fruits.

\section{Dietary Guidelines For Americans, 2000}

Aim for fitness

- Aim for a healthy weight.

- Be physically active each day.

Build a healthy base

- Let the Pyramid guide your food choices

- Choose a variety of grains daily, especially whole grains.

- Choose a variety of fruits and vegetables daily.

- $\quad$ Keep food safe to eat.

- $\quad$ Choose a diet low in fat, saturated fat, and cholesterol.

- Choose a diet moderate in sugars.

- Choose a diet moderate in salt and sodium.

- If you drink alcoholic beverages, do so in moderation.
Choose sensibly

- Choose a diet that is low in saturated fat and cholesterol and moderate in total fat.

- Choose beverages and foods to moderate you intake of sugars.

- Choose and prepare foods with less salt.

- If you drink alcoholic beverages, do so in moderation. 
Healthy People 2000 \& 2010: National Health Promotion and Disease Prevention

Objectives. Every decade, the U.S. Department of Health and Human Services (UDHHS) develops the Healthy People document that sets ten-year health objectives for the country. Healthy People 2000 contained 297 objectives covering 22 different areas of priority. The third review of progress on Healthy People 2000 objectives for nutrition (Public Health Service) indicated that some of the objectives had not been met as of 1998. While there were no specific objectives for reducing overweight in children, data indicated that overweight in children aged 6-11 years of age increased from 7.6 percent in 1976-80 to 13.6 percent in 1988-94. In addition, the population aged 2 years and older consumed an average of 4.6 daily servings of fruits and vegetables in 1994-96. This showed an increase from the 1989-91 baseline of 4.1. The year 2000 target was 5 servings for all age groups $>2$ years of age. The report also defined the status of fat intake in all individuals aged 2 years and older. In the baseline period of 1989-91, the proportion of total caloric intake from fat and saturated fat was 34 percent and 12 percent, respectively. Some progress was shown in the 1994-96 data indicating 33 percent of total energy intake from fat and 11 percent from saturated fat. The year 2000 targets for fat intake were 30 percent for fat and 10 percent for saturated fat.

Healthy People 2010 is representative of efforts to reach many of the goals that were not met by the 2000 objectives as well as addressing new concerns for the upcoming century (Sizer and Whitney, 2000). Healthy People 2010 Nutrition and Overweight Objectives related to the content of this paper are given in Table 2. 
Table 2. Healthy People 2010: Nutrition and Overweight Objectives

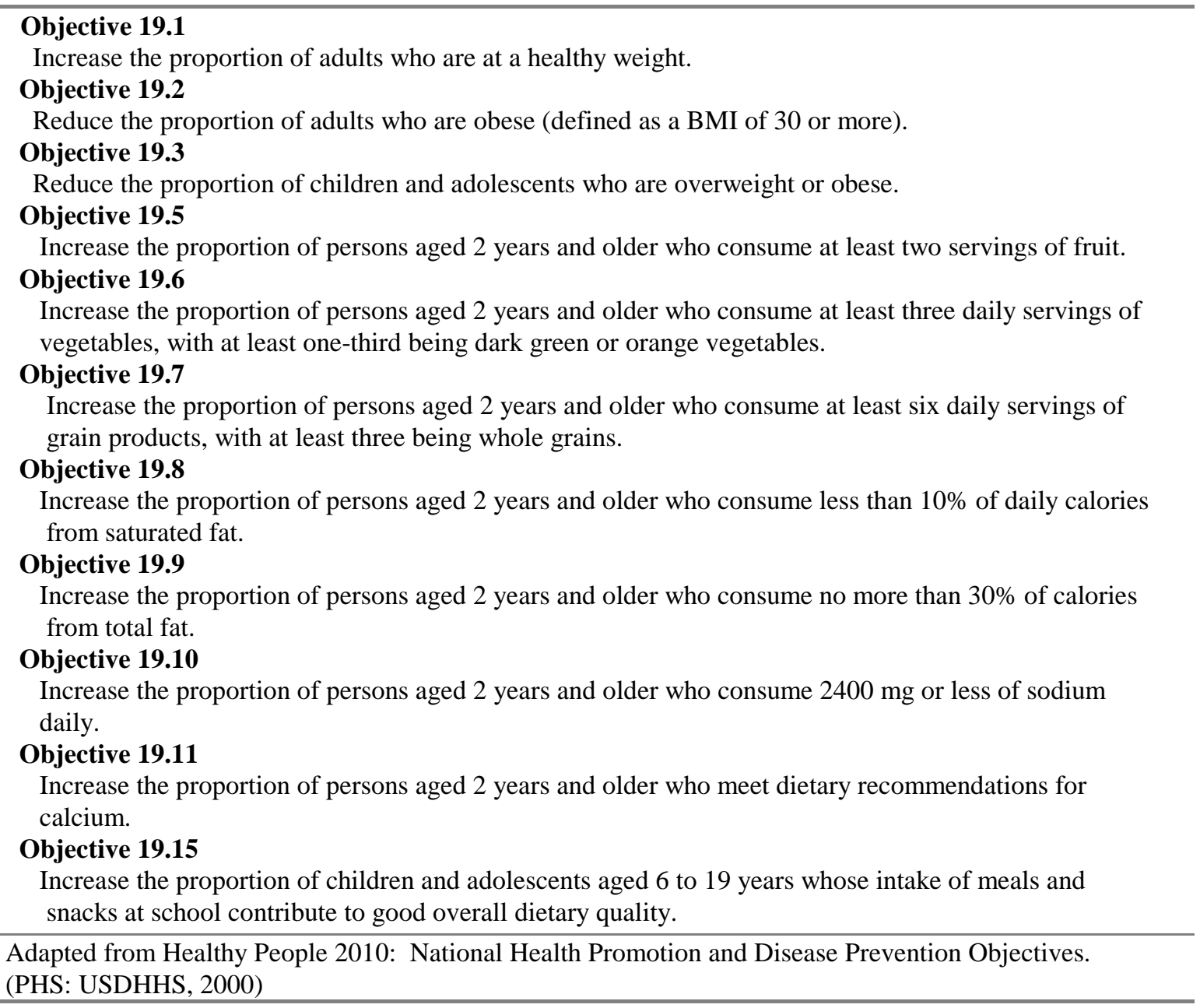

\section{The National School Lunch Program}

Standards for the National School Lunch Program. Dwyer (1995), summarized four distinct school nutrition revolutions in the United States. The focus of these revolutions has evolved since the late 19th century from an emphasis on feeding poor children who needed school meals to a current focus on adherence of school meals to the Dietary Guidelines for Americans (Public Health Service, 1995). This current revolution was consistent with the goal of the US Department of Health and Human Services Healthy People 2000 (Public Health Service: U.S. Department of Health \& Human Services, 1991), which stated that by 
the year 2000, 90\% of school lunches and breakfasts should have menus that are consistent with the Dietary Guidelines. Healthy People 2010 Objective 19.15 proposes a continued increase in the proportion of children aged 6 to 19 years whose intake of meals and snacks at school contributes to good overall dietary quality. Because the standards required by USDA for school lunches do not apply to foods sold in snack bars, school stores, vending machines and foods brought from home, efforts must be made in nutrition education and promotion to reach parents and children with tools to make wise nutrition choices.

Public Law 104-149, the School Meals Initiative for Healthy Children as discussed by Morris (1996), mandated the compliance of school meals to the Dietary Guidelines for Americans. The Healthy Meals for Healthy Children Act (HR 2066) specifically stated that the National School Lunch Program must provide one-third of the Recommended Dietary Allowances (RDAs) for protein, vitamin A, vitamin C, calcium, iron and energy. These federal standards were to be implemented by the 1996-97 school year unless waived by the state agency until 1998-99 (U.S. Department of Agriculture, 1995).

Effective February 13, 1997, the West Virginia Board of Education (WVBOE) adopted a revised set of standards for school nutrition ( 84321.1$)$ which apply not only to school meals but also to additional snacks, including foods and beverages sold or served to students (West Virginia Board of Education, 1994). Lunch Implementation Option A requires that school lunches meet the 1994-95 USDA meal pattern requirements and averaged over a period of one week or one month, provide: (a) at least one-third of students' RDAs for calories, protein, calcium, iron, vitamins A and vitamin C; (b) no more than $30 \%$ of energy intake from fat and no more than $10 \%$ of energy intake from saturated fat; (c) no more than $1100 \mathrm{mg}$. of sodium; (d) at least $6 \mathrm{~g}$. of naturally occurring dietary fiber; and (e) 
water as an optional/supplemental beverage. In addition to these standards, schools are prohibited from selling or serving any foods containing $40 \%$ or more sugar by weight and any juice or juice product sold or served must contain a minimum of $20 \%$ real juice. USDA meal pattern requirements include the following five components: a serving of meat or meat alternate, two or more servings of vegetables and/or fruits, one and one-half servings of whole-grain or enriched bread or bread alternate (containing at least 33\% whole grain), and one serving of milk. Minimum serving sizes are based on different age and grade groups. The offer versus serve option allows students to refuse up to two of these five components and still maintain a lunch that qualifies for government reimbursement (Burghardt \& Devaney, 1995). This option was designed primarily to reduce plate waste (Ho, Gould, Jensen, Kiser, Mozar \& Jensen, 1991).

Nutrient Contributions of School Lunch. Ho et al. (1991), utilized a visual plate waste study to determine that school lunches as consumed by Junior High students in Utah provided significantly higher $(\mathrm{p}<0.05)$ amounts of most nutrients than sack lunches. This study also determined that, as consumed, school lunch did not meet the dietary recommendations for percent of calories from carbohydrate, total and saturated fats, dietary fiber, and sodium. Devaney, Gordon and Burghardt (1995), found that a nationally representative sample of National School Lunch Program (NSLP) participants' mean intakes of most nutrients at lunch met the program goal of at least one-third of the RDA, but they consumed more fat, saturated fat, and sodium than recommended. A second study, conducted this same year, by Gordon, Devaney, and Burghardt (1995), used a 24-hour dietary recall to assess the effects of participation in the NSLP. Data indicated that NSLP 
participants had higher lunch intakes of vitamin A, calcium, and magnesium, and a lower intake of vitamin C than non-participants. This study also indicated that NSLP participation was associated with a higher percentage of food energy from fat and saturated fat. Similar data from 24-hour dietary intake interviews with 3,350 children in grades 1-12 maintained that NSLP participants consumed substantially more fluid milk, meats, grain-based mixtures containing meat or cheese, and vegetables at lunch than did non-participants. These trends lead to higher fat intakes than non-participants. Higher consumption of fluid milk by NSLP participants was indication for their higher intakes of vitamin A, calcium, and magnesium. Higher meat consumption increased the intakes of zinc by participants and higher vegetable consumption was responsible for a large contribution of vitamin A and minerals by the group. A summary and discussion of the School Nutrition Dietary Assessment Study by Burghardt, Devaney, \& Gordon (1995), offered suggestions for reducing fat in school lunches to within the standards set by the Dietary Guidelines. Some of the suggestions made in this 1995 study were to be solved in Public Law 104-149, with adherence to the Dietary Guidelines. Gordon \& McKinney (1995), noted that non-participants of the school lunch program were much more likely to consume cakes, cookies, salty snacks, and sweets at lunch and that higher vitamin $\mathrm{C}$ intake recorded for non-participants was due largely to their frequent consumption of fruitades fortified with vitamin C.

\section{Summary of Review of Literature}

The development of a healthy lifestyle begins in childhood and includes the ability to make wise food choices. The eating habits and tendencies toward overweight of American children indicate high risks for the development of diet-related diseases in adulthood. Recent 
federal and state regulation of the NSLP has maintained high standards for compliance with Healthy People 2000 and 2010 objectives, the Recommended Dietary Allowances, and the Dietary Guidelines for Americans. Since these recent standards were not mandated until the 1998-99 school year, previous studies quoted in this review of literature evaluated programs that did not fall under compliance with current mandates. In addition, recent work by the Institute of Medicine to develop the Dietary Reference Intakes have refined nutrient intake standards, providing better estimates for determining individual needs as well as those of groups. 


\section{CHAPTER III}

\section{METHODOLOGY}

This research study addressed two primary objectives. The first objective was to compare the nutrient content of packed lunches and school lunches as selected and consumed by elementary school students. A secondary objective was to determine whether school lunches and packed lunches as selected and consumed met the RDAs for children ages 7-10 years as well as some updated DRI values, and dietary guideline recommendations. The research objectives were met by taking an accurate weight of each student's lunch choices at the beginning of the lunch period and a follow-up weight of any waste left by the student at the end of the lunch period. The study replicated and expanded upon prior research conducted by Ho, Gould, Jensen, Kiser, Mozer, \& Jensen (1991), involving Junior High Students from Utah. The previous study utilized visual plate waste as the predominant method for data collection and a larger sample size.

\section{$\underline{\text { Variables }}$}

This study was concerned with the nutritional content of school and packed lunches as consumed during a regular school lunch period. The independent variable was the type of lunch consumed by the student: (i) school lunch (food items offered by school food service personnel including a choice of up to five school lunch components but not less than three of the five offerings) or (ii) packed lunch (food and/or beverages brought from home). The dependent variables for hypothesis one were the nutrient contents and nutrient intakes of school and packed lunches. The Recommended Dietary Allowances (RDAs), the Dietary 
Reference Intakes (DRIs), and the Dietary Guidelines for Americans determined the dependent variables for both hypotheses two and three. School and packed lunches as selected and consumed were compared with the standards given in Table $\mathbf{3}$ as guided by the above standards.

Table 3. Standards for Comparison of School and Packed Lunches

\begin{tabular}{|c|c|c|}
\hline Nutrient & $\begin{array}{c}\text { Unit of } \\
\text { Measurement }\end{array}$ & $\begin{array}{c}\text { Standards of Comparison } \\
\text { Ages (7-10)/Daily Recommendations }\end{array}$ \\
\hline Energy & Kilocalories & RDA=2000 Kilocalories/day* \\
\hline Carbohydrate & Kilocalories & $55-60 \%$ of Total Kilocalories \\
\hline Total Sugar & Kilocalories & $\leq 10 \%$ of Total Kilocalories*** \\
\hline Protein & Grams & RDA=28 g/day* \\
\hline Total Fat & Kilocalories & $\leq 30 \%$ of Total Kilocalories* \\
\hline Saturated Fat & Kilocalories & $\leq 10 \%$ of Total Kilocalories* \\
\hline Sodium & Milligrams & $\leq 1100 \mathrm{mg} /$ lunch meal** \\
\hline Dietary Fiber & Grams & $\geq 6 \mathrm{~g} /$ lunch meal** \\
\hline Iron & Milligrams & $\mathrm{RDA}=10 \mathrm{mg} / \mathrm{day}^{*}$ \\
\hline Vitamin A & Retinol Equivalents & RDA=700 RE/day* \\
\hline Zinc & Grams & $\mathrm{DRI}=5-8 \mathrm{~g} /$ day \\
\hline Calcium & Milligrams & $\mathrm{DRI}=800-1300 \mathrm{mg} / \mathrm{day}^{*}$ \\
\hline Phosphorus & Milligrams & $\mathrm{DRI}=500-1250 \mathrm{mg} / \mathrm{day}$ \\
\hline Magnesium & Milligrams & DRI = 130- $240 \mathrm{mg} / \mathrm{day}$ \\
\hline Vitamin D & Micrograms & $\mathrm{DRI}=5 \mu \mathrm{g} / \mathrm{day}$ \\
\hline Fluoride & Milligrams & $\mathrm{DRI}=1-2 \mathrm{mg} /$ day \\
\hline Vitamin C & Milligrams & $\mathrm{DRI}=25-45 \mathrm{mg} / \mathrm{day}^{*}$ \\
\hline Vitamin E & Grams & $\mathrm{DRI}=7-11 \mathrm{~g} / \mathrm{day}$ \\
\hline Thiamin & Milligrams & $\mathrm{DRI}=0.6-0.9 \mathrm{mg} / \mathrm{day}$ \\
\hline Riboflavin & Milligrams & $\mathrm{DRI}=0.6-0.9 \mathrm{mg} / \mathrm{day}$ \\
\hline Niacin & Milligrams & $\mathrm{DRI}=8-12 \mathrm{mg} / \mathrm{day}$ \\
\hline Vitamin $\mathrm{B}_{6}$ & Milligrams & $\mathrm{DRI}=0.6-1.0 \mathrm{mg} / \mathrm{day}$ \\
\hline Folate & Micrograms & $\mathrm{DRI}=200-300 \mu \mathrm{g} / \mathrm{day}$ \\
\hline Vitamin $\mathrm{B}_{12}$ & Micrograms & $\mathrm{DRI}=1.2-1.8 \mu \mathrm{g} / \mathrm{day}$ \\
\hline $\begin{array}{l}\text { Pantothenic } \\
\text { Acid }\end{array}$ & Milligrams & $\mathrm{DRI}=3-4 \mathrm{mg} / \mathrm{day}$ \\
\hline Biotin & Micrograms & $\mathrm{DRI}=12-20 \mu \mathrm{g} / \mathrm{day}$ \\
\hline \multicolumn{3}{|c|}{$\begin{array}{l}\text { *USDA Nutrient Standards For School Lunch; Calcium has been updated from the RDA value of } \\
800 \mathrm{mg} \text { to the } 800-1300 \text { DRI range; Vitamin C has been updated from the RDA value of } 45 \mathrm{mg} \text { to } \\
\text { the } 25-45 \mathrm{mg} \text { DRI range. } \\
\text { **Additional WVBOE standards for School Lunch (West Virginia Board of Education, 1994) } \\
\text { ***(WHO Population Nutrient Goals ,1990) }\end{array}$} \\
\hline
\end{tabular}


The lunch target for these nutrients was one-third $(\geq 33.3 \%)$ of the RDA/DRI unless otherwise indicated in Table 3. Intake of total fat as a percentage of food energy was evaluated at the recommended amount of $\leq 30 \%$ and saturated fat as a percentage of food energy at $\leq 10 \%$ based on the Dietary Guidelines for Americans (USDA \& USDHHS, 1995). The West Virginia Board of Education standards for sodium intake at $\leq 1100 \mathrm{mg} / \mathrm{meal}$ and dietary fiber at $\geq 6 \mathrm{~g} / \mathrm{meal}$ were used as the references for this study. Carbohydrate as a percentage of energy intake was evaluated for a target range of 55-60\% based on the Dietary Guidelines for Americans and total sugar as a percentage of energy at $\leq 10 \%$ based on the World Health Organization (WHO) Population Nutrient Goals (1990). It is important to note that according to USDA standards, nutrient values for school lunch programs need only be met through a one-week or one-month average of planned meals. In addition, school lunches do not have to provide one-third of all nutrients to be in compliance. Standards have only been set for total energy, protein, calcium, iron, vitamin $\mathrm{A}$, and vitamin $\mathrm{C}$ with additional West Virginia standards for sodium, fat, saturated fat, and fiber. For the purposes of this study, daily lunch nutrient intakes will be compared to daily standards so that a comparison can be made between the two types of lunches examined, namely school-prepared lunches and those brought from home.

\section{Subjects}

The participants in this study included 114 students from three elementary schools in Marion County, West Virginia. Students were selected on the basis of parental consent and their own assent to participate. The study included students in grades 2-5 who were in the age range of 7-10 years. The principals at three elementary schools (Watson Elementary, East 
Dale Elementary, and Barrackville Elementary) agreed to participate in the study. Each principal provided a letter of consent to the primary investigator. Copies of each letter have been provided in Appendix A. The three participating schools had free and reduced to regular lunch ratios of $51 \%, 49 \%$, and $47 \%$ respectively. These were representative of the average countywide free and reduced to regular lunch ratio of $44 \%$ (Marion County Board of Education, 2000). Households with income levels at or below $130 \%$ of poverty are eligible for free meals and those with incomes between 131 and 185\% of poverty are eligible for reduced priced meals (Food and Nutrition Service, 2001). In addition, the selected schools were representative of urban, rural, and suburban samples of the county population. According to the U.S. Bureau of Census, 1997, Marion County had an estimated population of 56,900 (West Virginia Department of Health \& Human Resources, 1999).

\section{$\underline{\text { Sample Selection }}$}

The primary investigator made initial contacts with each school participating in the study. A detailed explanation along with procedures of the study and who would be involved was given to the principal or assistant principal and to the foodservice staff.

An introductory letter and consent form (approved by the WVU-IRB Board) stating the basic procedures for the study were sent home to each parent/guardian with their child. Forms were sent to students in the second and fourth grades in the three schools initially. However, when returns from these two grades indicated low numbers of parental consent, the WVU-IRB Board approved an extension of the study to include students in the third and fifth grades as well. Copies of the consent form, assent form, cover letter, and IRB approvals for the protection of human subjects are provided in Appendix B. Signed consent forms were 
returned to the classroom teachers who forwarded them to the school administrator overseeing the study at that school. Data were collected on a total of 114 students with distribution as indicated in Table 4. All students that returned parental consent forms and assented to participate were included in the study.

Table 4. Student Distribution Among Three Participating Schools

\begin{tabular}{|l|c|c|}
\hline & $\begin{array}{c}\text { Packed Lunch } \\
\mathrm{N}=22\end{array}$ & $\begin{array}{c}\text { School Lunch } \\
\mathrm{N}=92\end{array}$ \\
\hline Watson Elementary & 5 & 24 \\
\hline Barrackville Elementary & 6 & 21 \\
\hline East Dale Elementary & 11 & 47 \\
\hline
\end{tabular}

\section{Procedures}

Data Collection. Data collection occurred on seven days randomly selected based on return of consent forms, and consideration of holidays and other school functions that might interfere with the regular lunch day. Care was taken so that a different entrée was being offered on each day of data collection. The principal was advised three days in advance of data collection to confirm approval. The principal was advised not to notify school foodservice staff or students as to the indicated date.

The primary investigator and one assistant were involved in data collection. The assistant recorded information on age, gender and grade for students as well as all food weights as measured by the investigator.

Students were excused from their class approximately one hour prior to the lunch period. They were instructed that the purpose of the study was to determine what types of food elementary school children eat. Each student received a copy of the assent form. The investigator read the assent form to the students and assured the students that they did not 
have to participate. The investigator explained that the student was to pick up his/her tray and bring it or his/her packed lunch directly to the weigh station upon entering the cafeteria. Each subject was assigned a number that was recorded on the top of the data collection form and on a colored dot they were to wear on their clothing or show to the foodservice staff as they went through the lunch line. This allowed the staff to recognize which students were participants so that certain foods could be placed into disposable food containers for ease and accuracy in weighing. Students were also instructed not to eat anything until their lunch had been weighed and not to discard any food or wrappings after eating until a second weight had been taken. After explaining all directions to the students, they were asked to sign the assent form if they would like to participate in the food study. Only one student declined participation in the study after parental consent had been provided. After each student signed the assent form or declined participation, they returned to their regular class and attended lunch at the scheduled time. The principal at each school agreed to allow the participants additional time to eat if needed as a result of time consumed in data collection.

Measurement. Disposable food containers were supplied to food service staff for use with certain menu items to facilitate accuracy in weighing. Examples of such items were chicken potpie and salad. The primary investigator and assistant followed all standards of food sanitation and safety as defined by the West Virginia Health Department, (2000). Disposable gloves and disposable food containers were used in handling all food items during weighing. A digital scale readable to 0.1 gram was used for all weights (Acculab, 2000). The scale was calibrated prior to each use. A data collection form developed by Ho et al. (1991), in a similar study was revised slightly for the purposes of this research. A letter of consent for use and adaptation of this form from the primary investigator of the former 
study was obtained. Copies of the letter and revised data collection form are given in Appendix C. Each form provided a space to identify the subject by identification number, age, gender, and grade level.

Food items and amounts selected by the student from school lunch or packed lunch were weighed and recorded to the 0.1 gram. Prepackaged lunch items with standardized weights were recorded as per packaging. Standard items among students such as milk were weighed with the container, and a standard container weight was subtracted from the total weight. This procedure was used for condiments and other prepackaged foods as well. Combination items such as sandwiches in either packed or school lunches were recorded as total weights for the whole sandwich. No attempt was made to disassemble combination items during the weighing process. Initial food weights were recorded in the first column of the data collection form. The amount of each food item remaining after the student completed the meal was weighed and recorded in the second column. The third column on the form was used to indicate the amount of food consumed as a difference between column one (food chosen/provided) and column two (food wasted). Data was collected in all schools during two separate lunch periods. The dates and distribution for the data collection among schools and lunch periods are indicated in Table 5.

Table 5. Date and Distribution of Subjects in Data Collection

\begin{tabular}{|l|l|c|c|}
\hline \multicolumn{1}{|c|}{ Date } & \multicolumn{1}{|c|}{ School } & $\begin{array}{c}\text { Data Collected } \\
\text { Lunch 1 }\end{array}$ & $\begin{array}{c}\text { Data Collected } \\
\text { Lunch 2 }\end{array}$ \\
\hline $3-13-00$ & Watson & 6 & 13 \\
\hline $3-15-00$ & Barrackville & 7 & 8 \\
\hline $3-20-00$ & East Dale & 15 & 10 \\
\hline $4-5-00$ & Barrackville & 7 & 5 \\
\hline $4-7-00$ & Watson & 3 & 7 \\
\hline $4-19-00$ & East Dale & 9 & 5 \\
\hline $4-20-00$ & East Dale & 8 & 11 \\
\hline
\end{tabular}


Nutritional Analysis. The amount of food actually consumed by each student was determined after data collection by completing column three on the data collection form. Weights for containers and wrappers were also subtracted at this time from both initial food weights and weights of food wasted. School lunch menu items that were combination dishes such as chicken potpie, chili, etc. were left as total weights for the menu item. Weights for combination food items sent from home such as a ham and cheese sandwich were calculated using a ratio. A table of food values (Pennington, 1994) and Nutritionist V nutrient analysis software (First Data Bank, 1995) were used to develop a standard weight for a sandwich composed of the items making up the packed sandwich. Each item weight was then determined as a ratio of that standard weight sandwich. Using these ratios and the total weight of the packed lunch sandwich, individual weights for food items making up the packed sandwich were determined. The same procedure was used for all packed lunch items that were not prepackaged. An example of this procedure is provided in Appendix D. School lunch menu items that were combination dishes were analyzed using Nutritionist $\mathrm{V}$ by entering the ingredients and saving them under a recipe file. This recipe was later retrieved and used to analyze tray content and intake for each subject choosing that item on his/her tray. Appendix E provides a copy of the county menus for the months of March and April, foodservice production records and recipes supplied by the Marion County Child Nutrition Director for each day of data collection (Marion County Board of Education, 2000), and menu items as entered into Nutritionist V for nutrient analysis. Some USDA standardized recipes used by the county were already available in the Nutritionist $\mathrm{V}$ database and therefore did not have to be entered manually. 
Initial food amounts from column one and total food amounts consumed from column three of the data collection form were analyzed using Nutritionist V software. Each individual student meal selected and consumed was analyzed for all nutrients in the database except for the amino acids, moisture, and ash.

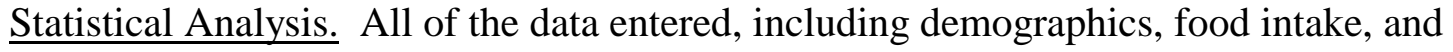
nutrient intake, were analyzed using Statistica for Windows (Statsoft, 1995). The dependent variables were: (a) nutrient value provided or selected in each lunch, (b) nutrient value wasted in each lunch, (c) nutrient value consumed from each lunch, (d) percent of recommended nutrient standard available in each lunch, (e) percent of recommended nutrient standard consumed from each lunch, (f) percent of students offered the recommended nutrient standard in their lunch as selected or provided, and $(\mathrm{g})$ percent of students with nutrient intake that met the recommended standard. The independent variable was the type of lunch chosen..

Data entered were statistically analyzed for descriptive statistics (mean and standard deviation), Analysis of Variance (ANOVA), and Tukeys Honestly Significant Difference for Unequal N (HSD.UEN). HSD.UEN was used due to the difference in the sample sizes among students eating school lunch and those eating packed lunch. These statistical tests determined significant differences between mean nutrient contents and intakes of school lunch and packed lunch at $\mathrm{p}<0.05$ and $\mathrm{p}<0.01$ levels (Statsoft, 1995). 


\section{CHAPTER IV}

\section{RESULTS}

The objectives of this study were to compare the nutritional value of school lunch and packed lunch and to determine if these lunch options met RDA and DRI nutrient standards for children ages 7-10 and the Dietary Guidelines for Americans. A total of $114(\mathrm{~N}=114)$ lunches were analyzed for nutrient composition.

\section{Demographics}

Table 6 provides demographic information on subjects by school, age, gender and type of lunch option. Results indicate that of the 114 subjects, half attended East Dale Elementary (50.9\%), with remaining subjects almost evenly distributed between Barrackville Elementary (23.7\%) and Watson Elementary (25.4\%). Distribution among age groups varied as well with only $5.3 \%$ of 7 -year olds, $27.2 \%$ of 8 -year olds, and $14.9 \%$ of 10 -year olds participating in the study. Over half of the sample group (52.6\%) was 9 years of age. According to gender, the distribution was not as broad with $58.8 \%$ female subjects and 41.2\% male subjects participating. Distribution of subjects by type of lunch was broad with only $19.3 \%$ of subjects eating packed lunch and $80.7 \%$ of subjects eating school lunch. 
Table 6. Descriptive analysis of the number (n) and percent of participants according to school, age distribution, gender, and type of lunch consumed. $(\mathrm{N}=114)$

\begin{tabular}{lcc}
\hline Factor & $\mathrm{n}$ & Percent \\
\hline School & & \\
$\quad$ Barrackville & 27 & 23.7 \\
East Dale & 58 & 50.9 \\
Watson & 29 & 25.4 \\
Age & & \\
7 & 6 & 5.3 \\
8 & 31 & 27.2 \\
9 & 60 & 52.6 \\
10 & 17 & 14.9 \\
Gender & & \\
Female & 67 & 58.8 \\
Male & 47 & 41.2 \\
Type of Lunch & & \\
School & 92 & 80.7 \\
Packed & 22 & 19.3 \\
\hline
\end{tabular}

\section{$\underline{\text { Energy and Macronutrients }}$}

Table 7 through Table 12 provide mean values of the energy and macronutrient content and intake between school lunch and lunch from home, the percentage of the energy and macronutrient standard available in the lunch, the percentage of the energy and macronutrient standard consumed from the lunch, the percentage of students who were offered or selected lunches with energy and macronutrient values that complied with the defined nutrient standard, and the percentage of students who had energy and macronutrient intakes meeting the defined nutrient standards. The values given were used to determine differences between the lunch choices in regard to nutrient content and intake and to interpret the adequacy of each option as offered or selected and consumed.

School lunches and packed lunches, as determined by this study, provided adequate amounts of energy as selected or provided, however, only slightly over one-fourth of students eating school lunch and one-half of those eating packed lunch consumed one-third of the day's RDA. 
Both types of lunch provided well above the RDA for grams of protein, with school lunch providing significantly higher amounts than packed lunch at $\mathrm{p}<0.01$. Differences in intake of protein were not significant between the two lunches but both groups had mean intakes at or above the one-third of RDA goal.

There were no significant differences between the two lunch types for energy available as carbohydrate or for energy available as fat or as saturated fat. Students eating packed lunch, on the average, consumed a larger percent of that energy from carbohydrate than those who ate school lunch. Almost half of students eating school lunch had intakes of $\leq 30 \%$ of total energy from fat while only one-third of students bringing lunch from home had energy intakes that met this standard. While school lunches, as selected, provided higher amounts of saturated fat than packed lunches, there was little difference in the intake of energy as saturated fat between both lunch types.

Energy available as sugar and intake of energy in the form of sugar were significantly higher at $\mathrm{p}<0.01$ for packed lunches over school lunches. 
Table 7. Energy Content and Intake of Student Lunches From School or Home

\begin{tabular}{|l|c|c|}
\hline & $\begin{array}{c}\text { School Tray } \\
(\mathrm{N}=92)\end{array}$ & $\begin{array}{c}\text { Lunch From Home } \\
(\mathrm{N}=22)\end{array}$ \\
\hline $\begin{array}{l}\text { Energy Available in Lunch as Selected/Provided (Kcal.) } \\
\text { Energy Not Consumed (Kcal.) }\end{array}$ & $797 \pm 237$ & $828 \pm 244$ \\
Energy Intake (Kcal.) & $237 \pm 193$ & $161 \pm 180$ \\
& $560 \pm 276$ & $667 \pm 259$ \\
\hline $\begin{array}{l}\% \text { of RDA }{ }^{\dagger} \text { Available in Lunch as Selected/Provided } \\
\% \text { of RDA }{ }^{\dagger} \text { Consumed }\end{array}$ & $39.9 \pm 11.9$ & $41.4 \pm 12.2$ \\
\hline $\begin{array}{l}\% \text { of Student Lunches With } \geq 33.3 \% \text { of } \mathrm{RDA}^{\dagger} \\
\% \text { of Students With Intake } \geq 33.3 \% \text { of RDA }\end{array}$ & $28.0 \pm 13.8$ & $33.4 \pm 13.0$ \\
\hline $\begin{array}{l}{ }^{\dagger} \\
{ }^{\dagger} \text { RDA foan }+ \text { SD Energy=2000 Kcal (7-10 y) (FNB, 1989) }\end{array}$ & $66.3 \pm 47.5$ & $81.8 \pm 39.5$ \\
\hline
\end{tabular}

Table 8. Protein Content and Intake of Student Lunches From School or Home

\begin{tabular}{|c|c|c|}
\hline & $\begin{array}{c}\text { School Tray } \\
(\mathrm{N}=92)\end{array}$ & $\begin{array}{l}\text { Lunch From Home } \\
\qquad(\mathrm{N}=22)\end{array}$ \\
\hline Protein Available in Lunch as Selected/Provided (g) & $31.4 \pm 9.1 * *$ & $18.9 \pm 7.2$ \\
\hline Protein Not Consumed $(\mathrm{g})$ & $10.0 \pm 9.7 * *$ & $2.7 \pm 4.2$ \\
\hline Protein Intake $(\mathrm{g})$ & $21.0 \pm 10.0$ & $16.1 \pm 7.0$ \\
\hline $\begin{array}{l}\% \text { of } \mathrm{RDA}^{\dagger} \text { Available in Lunch as Selected/Provided } \\
\% \text { of } \mathrm{RDA}^{\dagger} \text { Consumed }\end{array}$ & $\begin{array}{l}112 \pm 33^{* * *} \\
76 \pm 36\end{array}$ & $\begin{array}{l}67 \pm 26 \\
58 \pm 25\end{array}$ \\
\hline $\begin{array}{l}\% \text { of Students Lunches With } \geq 33.3 \% \text { of } \mathrm{RDA}^{\dagger} \\
\% \text { of Students With Intake } \geq 33.3 \% \text { of } \mathrm{RDA}^{\dagger}\end{array}$ & $\begin{array}{l}100 \pm 0 * * \\
85 \pm 36\end{array}$ & $\begin{array}{l}86 \pm 35 \\
82 \pm 39\end{array}$ \\
\hline \multicolumn{3}{|c|}{$\begin{array}{l}\text { Mean } \pm \text { SD } \\
* * \text { Tukey Honest Significant Difference for Unequal N (HSD.UEN), } \mathrm{p}<0.01 \\
{ }^{\top} \mathrm{RDA} \text { for Protein }=28 \mathrm{~g}(7-10 \mathrm{y}),(\mathrm{FNB}, 1989)\end{array}$} \\
\hline
\end{tabular}


Table 9. Carbohydrate (CHO) Energy Content and Intake of Student Lunches From School or Home

\begin{tabular}{|c|c|c|}
\hline & $\begin{array}{l}\text { School Tray } \\
(\mathrm{N}=92)\end{array}$ & $\begin{array}{l}\text { Lunch From Home } \\
\qquad(\mathrm{N}=22)\end{array}$ \\
\hline CHO Energy Available in Lunch as Selected/Provided (Kcal.) & $417 \pm 158$ & $482 \pm 132$ \\
\hline CHO Energy Not Consumed (Kcal.) & $110 \pm 106$ & $99 \pm 115$ \\
\hline CHO Energy Intake (Kcal.) & $307 \pm 165$ & $383 \pm 145$ \\
\hline$\%$ of $\mathrm{CHO}^{\dagger}$ Energy Available in Lunch as Selected/Provided & $52.3 \pm 10.0$ & $58.9 \pm 6.4$ \\
\hline$\%$ of $\mathrm{CHO}^{\dagger}$ Energy Consumed & $54.9 \pm 11.6$ & $58.2 \pm 7.1$ \\
\hline $\begin{array}{l}\% \text { of Student Lunches Having 55-60\% of Energy Available } \\
\text { asCHO }\end{array}$ & $16.3 \pm 37.1$ & $27.3 \pm 45.6$ \\
\hline$\%$ of Students With $55-60 \%$ of Energy Intake as $\mathrm{CHO}^{\dagger}$ & $12.0 \pm 32.6$ & $27.3 \pm 45.6$ \\
\hline \multicolumn{3}{|l|}{ Mean \pm SD } \\
\hline
\end{tabular}

Table 10. Content and Intake of Energy from Fat in Student Lunches From School or Home

\begin{tabular}{|c|c|c|}
\hline & $\begin{array}{l}\text { School Tray } \\
(\mathrm{N}=92)\end{array}$ & $\begin{array}{l}\text { Lunch From Home } \\
(\mathrm{N}=22)\end{array}$ \\
\hline Energy from Fat Available in Lunch as Selected/Provided (kcal.) & $263 \pm 109$ & $287 \pm 119$ \\
\hline Energy from Fat Not Consumed (kcal.) & $89 \pm 80$ & $54 \pm 69$ \\
\hline Intake of Energy from Fat (kcal.) & $173 \pm 104$ & $232 \pm 117$ \\
\hline$\%$ Total Energy Available from Fat ${ }^{\dagger}$ in Lunch as & $32.6 \pm 7.8$ & $33.7 \pm 5.9$ \\
\hline Selected/Provided & $30.4 \pm 8.8$ & $33.6 \pm 6.6$ \\
\hline$\%$ of Total Energy Consumed from Fat ${ }^{\dagger}$ & & \\
\hline$\%$ of Student Lunches With $\leq 30 \%$ of Total Energy from Fat ${ }^{\dagger}$ & $37 \pm 48$ & $32 \pm 48$ \\
\hline$\%$ of Student With Intake $\leq 30 \%$ Total Energy from Fat ${ }^{\dagger}$ & $47 \pm 50$ & $32 \pm 48$ \\
\hline \multicolumn{3}{|l|}{ Mean + SD } \\
\hline
\end{tabular}


Table 11.Content and Intake of Energy from Saturated Fat in Student Lunches From School or Home

\begin{tabular}{|c|c|c|}
\hline & $\begin{array}{l}\text { School Tray } \\
(\mathrm{N}=92)\end{array}$ & $\begin{array}{l}\text { Lunch From Home } \\
\qquad(\mathrm{N}=22)\end{array}$ \\
\hline $\begin{array}{l}\text { Energy from Saturated Fat Available in Lunch as } \\
\text { Selected/Provided (kcal) }\end{array}$ & $93 \pm 39$ & $85 \pm 47$ \\
\hline Energy from Saturated Fat Not Consumed (kcal) & $27 \pm 25$ & $16 \pm 28$ \\
\hline Energy from Saturated Fat Intake (kcal) & $65 \pm 43$ & $69 \pm 39$ \\
\hline $\begin{array}{l}\% \text { Total Energy Available from Saturated Fat }{ }^{\dagger} \text { in Lunch as } \\
\text { Selected/Provided }\end{array}$ & & $10 \pm 3.4$ \\
\hline$\%$ of Total Energy Consumed from Saturated Fat ${ }^{\dagger}$ & $11 \pm 3.9$ & $10 \pm 3.3$ \\
\hline $\begin{array}{l}\% \text { of Student Lunches With } \leq 10 \% \text { of Total Energy from } \\
\text { Saturated Fat }\end{array}$ & $29 \pm 46$ & $46 \pm 51$ \\
\hline $\begin{array}{l}\% \text { of Student With Intake } \leq 10 \% \text { of Total Energy from } \\
\text { Saturated Fat }\end{array}$ & $36 \pm 48$ & $41 \pm 50$ \\
\hline \multicolumn{3}{|l|}{ Mean + SD } \\
\hline
\end{tabular}

Table 12. Content and Intake of Energy from Sugar in Student Lunches From School or Home

\begin{tabular}{|c|c|c|}
\hline & $\begin{array}{l}\text { School Tray } \\
\qquad(N=92)\end{array}$ & $\begin{array}{l}\text { Lunch From Home } \\
\qquad(\mathrm{N}=22)\end{array}$ \\
\hline $\begin{array}{l}\text { Energy from Sugar Available in Lunch as Selected/Provided (Kcal) } \\
\text { Energy from Sugar Not Consumed (Kcal) } \\
\text { Energy Intake from Sugar (Kcal) }\end{array}$ & $\begin{array}{l}121 \pm 69 * * \\
37 \pm 42 \\
83 \pm 59 * *\end{array}$ & $\begin{array}{r}229 \pm 82 \\
46 \pm 69 \\
183 \pm 85\end{array}$ \\
\hline $\begin{array}{l}\% \text { of Energy Available from Sugar }{ }^{\dagger} \text { in Lunch as Selected/Provided } \\
\% \text { of Energy Consumed from Sugar }{ }^{\dagger}\end{array}$ & $\begin{array}{l}16.0 \pm 9.7 * * \\
16.0 \pm 13.0 * *\end{array}$ & $\begin{array}{l}28.0 \pm 6.6 \\
28.0 \pm 9.0\end{array}$ \\
\hline $\begin{array}{l}\% \text { of Student Lunches With } \leq 10 \% \text { of Energy from Sugar }{ }^{\dagger} \\
\% \text { of Students With Intake } \leq 10 \% \text { of Energy from Sugar }\end{array}$ & $\begin{array}{l}24.2 \pm 43.1 * \\
31.5 \pm 46.7 *\end{array}$ & $\begin{array}{c}0 \\
4.5 \pm 21.3\end{array}$ \\
\hline \multicolumn{3}{|l|}{$\begin{array}{l}\text { Mean } \pm \text { SD } \\
* \text { Tukey Honest Significant Difference for Unequal N (HSD.UEN), } \mathrm{p}<0.05 \\
* * \text { HSD.UEN, } \mathrm{p}<0.01 \\
{ }^{\dagger} \text { Sugar Recommendation }=\leq 10 \% \text { of Total Energy }(\text { WHO, 1990) }\end{array}$} \\
\hline
\end{tabular}




\section{$\underline{\text { Nutrients and Fiber Related to USDA and WVBOE Standards }}$}

Comparisons of content and intake of sodium, dietary fiber, iron, vitamin A, and zinc among school and packed lunches are given in Table 13 through Table 17.

School lunches, as selected, were significantly higher than packed lunches in dietary fiber, vitamin $A$, and zinc at $\mathrm{p}<0.01$. Intake of zinc was significantly higher from school lunches at $\mathrm{p}<0.01$ and intake of dietary fiber was significantly higher at $\mathrm{p}<0.05$. No significance was indicated for intake of dietary fiber or vitamin A between the two lunch choices. Differences in sodium and iron content and intake were not significant between school lunches and lunches provided from home.

Differences in the percentage of lunches providing the recommended standard of $\geq 6$ grams of dietary fiber were significant between school and packed lunches at $p<0.05$ but there was no significant difference in the percentage of students with intakes that met the recommended standard. Significance was indicated at $\mathrm{p}<0.01$ for percentage of lunches providing at least one-third of the RDA standard for vitamin A and zinc. The percentage of students with intake of vitamin A was significantly higher from school lunch at $\mathrm{p}<0.01$ and the percentage of students with intake of zinc from school lunch was higher at $\mathrm{p}<0.01$ level of significance. 
Table 13. Sodium Content and Intake of Student Lunches From School or Home

\begin{tabular}{|c|c|c|}
\hline & $\begin{array}{c}\text { School Tray } \\
(\mathrm{N}=92)\end{array}$ & $\begin{array}{l}\text { Lunch From Home } \\
\qquad(\mathrm{N}=22)\end{array}$ \\
\hline Sodium Available in Lunch as Selected/Provided (mg) & $1569 \pm 922$ & $1155 \pm 514$ \\
\hline Sodium Not Consumed (mg) & $594 \pm 596^{*}$ & $185 \pm 239$ \\
\hline Sodium Intake (mg) & $975 \pm 789$ & $970 \pm 529$ \\
\hline$\%$ of Students Lunches $\leq 1100 \mathrm{mg}$ Sodium $^{\dagger}$ & $40.2 \pm 49.3$ & $50.0 \pm 51.2$ \\
\hline$\%$ of Students With Intake $\leq 1100 \mathrm{mg} \mathrm{Sodium}^{\dagger}$ & $77.2 \pm 42.2$ & $54.5 \pm 51.0$ \\
\hline \multicolumn{3}{|c|}{$\begin{array}{l}\text { Mean } \pm \text { SD } \\
* \text { Tukey Honest Significant Difference for Unequal N (HSD.UEN), }<<0.05 \\
{ }^{\dagger} \text { Sodium Recommendation is } \leq 1100 \mathrm{mg} / \text { meal (WVDE, 1994). }\end{array}$} \\
\hline
\end{tabular}

Table 14. Dietary Fiber Content and Intake of Student Lunches From School or Home

\begin{tabular}{|c|c|c|}
\hline & $\begin{array}{l}\text { School Tray } \\
(\mathrm{N}=92)\end{array}$ & $\begin{array}{l}\text { Lunch From Home } \\
\qquad(\mathrm{N}=22)\end{array}$ \\
\hline Fiber Available in Lunch as Selected/Provided (g) & $6.5 \pm 2.5 * *$ & $4.4 \pm 1.6$ \\
\hline Fiber Not Consumed $(\mathrm{g})$ & $2.3 \pm 2.3^{*}$ & $0.9 \pm 1.0$ \\
\hline Fiber Intake $(\mathrm{g})$ & $4.2 \pm 2.1$ & $3.5 \pm 1.5$ \\
\hline$\%$ of Student Lunches With $\geq 6 \mathrm{~g}$ Fiber $^{\dagger}$ & $46.7 \pm 50.2^{*}$ & $18.2 \pm 39.5$ \\
\hline$\%$ of Students With Intake $\geq 6 \mathrm{~g}$ Fiber $^{\dagger}$ & $17.4 \pm 38.1$ & $4.5 \pm 21.3$ \\
\hline \multicolumn{3}{|c|}{$\begin{array}{l}\text { Mean } \pm \text { SD } \\
* \text { Tukey Honest Significant Difference for Unequal N (HSD.UEN), } \mathrm{p}<0.05 \\
* * \text { HSD.UEN, } \mathrm{p}<0.01 \\
{ }^{\dagger} \text { Dietary Fiber Recommendation is } \geq 6 \mathrm{~g} / \mathrm{meal} \text { (WVDE, 1994). }\end{array}$} \\
\hline
\end{tabular}


Table 15. Iron Content and Intake of Student Lunches From School or Home

\begin{tabular}{|l|c|c|}
\hline & $\begin{array}{c}\text { School Tray } \\
(\mathrm{N}=92)\end{array}$ & $\begin{array}{c}\text { Lunch From Home } \\
(\mathrm{N}=22)\end{array}$ \\
\hline Iron Available in Lunch as Selected/Provided (mg) & $4.0 \pm 1.1$ & $4.0 \pm 1.6$ \\
Iron Not Consumed (mg) & $1.2 \pm 1.1$ & $0.7 \pm 0.8$ \\
Iron Intake (mg) & $2.8 \pm 1.3$ & $3.4 \pm 1.7$ \\
\hline \% of RDA ${ }^{\dagger}$ Available in Lunch as Selected/Provided & $40.2 \pm 10.8$ & $40.4 \pm 16.0$ \\
$\%$ of RDA ${ }^{\dagger}$ Consumed & $27.8 \pm 13.3$ & $33.6 \pm 17.0$ \\
\hline \% of Student Lunches With $\geq 33.3 \%$ of $\mathrm{RDA}^{\dagger}$ & $73.9 \pm 44.2$ & $68.2 \pm 47.7$ \\
$\%$ of Students With Intake $\geq 33.3 \%$ of RDA & \\
\hline & $34.8 \pm 47.9$ & $50.0 \pm 51.2$ \\
\hline Mean + SD & & \\
${ }^{\dagger}$ RDA for Iron=10 mg (7-10 y) (FNB, 1989) & & \\
\hline
\end{tabular}

Table 16. Vitamin A Content and Intake of Student Lunches From School or Home

\begin{tabular}{|c|c|c|}
\hline & $\begin{array}{l}\text { School Tray } \\
(\mathrm{N}=92)\end{array}$ & $\begin{array}{l}\text { Lunch From Home } \\
\qquad(\mathrm{N}=22)\end{array}$ \\
\hline Vitamin A Available in Lunch as Selected/Provided (RE) & $560 \pm 321 * *$ & $263 \pm 322$ \\
\hline Vitamin A Not Consumed (RE) & $182 \pm 250^{*}$ & $18 \pm 38$ \\
\hline Vitamin A Intake (RE) & $379 \pm 272$ & $245 \pm 321$ \\
\hline$\%$ of RDA $^{\dagger}$ Available in Lunch as Selected/Provided & $80.1 \pm 45.9 * *$ & $37.5 \pm 45.9$ \\
\hline$\%$ of $\mathrm{RDA}^{\dagger}$ Consumed & $54.1 \pm 38.9$ & $35.0 \pm 45.9$ \\
\hline$\%$ of Students Lunches With $\geq 33.3 \%$ of $\mathrm{RDA}^{\dagger}$ & $87.0 \pm 33.9 * *$ & $31.9 \pm 47.7$ \\
\hline$\%$ of Students With Intake $\geq 3 \overline{3} .3 \%$ of $\mathrm{RDA}^{\dagger}$ & $66.3 \pm 47.5^{*}$ & $31.8 \pm 47.7$ \\
\hline \multicolumn{3}{|c|}{$\begin{array}{l}\text { Mean }+ \text { SD } \\
* \text { Tukey Honest Significant Difference for Unequal N (HSD.UEN), } p<0.05 \\
* * \text { HSD.UEN, } p<0.01 \\
{ }^{*} \text { RDA for Vitamin } A=700 \text { RE (FNB.1989) }\end{array}$} \\
\hline
\end{tabular}


Table 17. Zinc Content and Intake of Student Lunches From School or Home

\begin{tabular}{|c|c|c|}
\hline & $\begin{array}{l}\text { School Tray } \\
(\mathrm{N}=92)\end{array}$ & $\begin{array}{l}\text { Lunch From Home } \\
\qquad(\mathrm{N}=22)\end{array}$ \\
\hline $\begin{array}{l}\text { Zinc Available in Lunch as Selected/Provided (mg) } \\
\text { Zinc Not Consumed (mg) } \\
\text { Zinc Intake (mg) }\end{array}$ & $\begin{array}{l}3.6 \pm 1.4^{* *} \\
1.1 \pm 1.5^{*} \\
2.6 \pm 1.6^{* *}\end{array}$ & $\begin{array}{l}1.6 \pm 0.6 \\
0.2 \pm 0.4 \\
1.4 \pm 0.6\end{array}$ \\
\hline $\begin{array}{l}\% \text { of DRI }{ }^{\dagger} \text { Available in Lunch as Selected/Provided } \\
\% \text { of DRI }{ }^{\dagger} \text { Consumed }\end{array}$ & $\begin{array}{l}56.4 \pm 25.4 * * \\
39.6 \pm 27.7 * *\end{array}$ & $\begin{array}{l}22.1 \pm 10.8 \\
18.6 \pm 8.5\end{array}$ \\
\hline $\begin{array}{l}\% \text { of Students Lunches With } \geq 33.3 \% \text { of DRI } \\
\% \text { of Students With Intake } \geq 33.3 \% \text { of DRI }\end{array}$ & $\begin{array}{l}77.2 \pm 42.2^{* *} \\
51.1 \pm 50.3^{* *}\end{array}$ & $\begin{array}{c}14.3 \pm 35.9 \\
9.5 \pm 30.1\end{array}$ \\
\hline \multicolumn{3}{|c|}{$\begin{array}{l}\text { Mean }+ \text { SD } \\
* \text { Tukey Honest Significant Difference for Unequal N (HSD.UEN), p }<0.05 \\
\text { **HSD.UEN, p }<0.01 \\
{ }^{\top} \text { Zinc DRI }=5 \mathrm{mg} / \text { day (4-8y); } 8 \mathrm{mg} / \text { day (9-13y) (IOM, 2001) }\end{array}$} \\
\hline
\end{tabular}

\section{Nutrients Related to Osteoporosis and Other Bone-related Diseases}

Average content and intake of the bone related nutrients as well as comparisons to the newly defined DRI standards for these vitamins and minerals are indicated in Table 18 through Table 22.

School lunches were significantly higher in all of the bone-related nutrients at $p<0.01$. Intake of these nutrients from school lunch was also significantly higher at $p<0.01$ with the exception of calcium which was significantly higher at $\mathrm{p}<0.05$. The percentage of school lunches meeting or exceeding the recommended DRI standard was significantly higher at $\mathrm{p}<0.01$ for calcium, phosphorus, magnesium, and vitamin D. The percent of students with intake from school lunches meeting or exceeding the standard was significantly higher at $\mathrm{p}<0.01$ for phosphorus, magnesium, and vitamin $\mathrm{D}$ and for calcium at $\mathrm{p}<0.05$. 
Table 20. Magnesium Content and Intake of Student Lunches From School or Home

\begin{tabular}{|c|c|c|}
\hline & $\begin{array}{l}\text { School Tray } \\
(\mathrm{N}=92)\end{array}$ & $\begin{array}{l}\text { Lunch From Home } \\
(\mathrm{N}=22)\end{array}$ \\
\hline $\begin{array}{l}\text { Magnesium Available in Lunch as Selected/Provided } \\
(\mathrm{mg}) \\
\text { Magnesium Not Consumed (mg) } \\
\text { Magnesium Intake (mg) }\end{array}$ & $\begin{array}{l}79 \pm 22 * * \\
20 \pm 20 * \\
59 \pm 27 * *\end{array}$ & $\begin{array}{c}39 \pm 18 \\
6.0 \pm 8.0 \\
33 \pm 17\end{array}$ \\
\hline $\begin{array}{l}\% \text { of DRI }{ }^{\dagger} \text { Available in Lunch as Selected/Provided } \\
\% \text { of } \mathrm{DRI}^{\dagger} \text { Consumed }\end{array}$ & $\begin{array}{l}43.9 \pm 20.0^{* * *} \\
32.7 \pm 18.9 * *\end{array}$ & $\begin{array}{l}18.7 \pm 12.4 \\
15.5 \pm 11.0\end{array}$ \\
\hline $\begin{array}{l}\% \text { of Students Lunches With } \geq 33.3 \% \text { of DRI } \\
\% \text { of Students With Intake } \geq 33.3 \% \text { of } \mathrm{DRI}^{\dagger}\end{array}$ & $\begin{array}{l}60.9 \pm 49.1 * * \\
40.2 \pm 49.3 * *\end{array}$ & $\begin{array}{l}4.8 \pm 21.8 \\
4.8 \pm 21.8\end{array}$ \\
\hline \multicolumn{3}{|c|}{$\begin{array}{l}\text { Mean } \pm \text { SD } \\
* \text { Tukey Honest Significant Difference for Unequal N (HSD.UEN), }<<0.05 \\
* * \text { HSD.UEN, } p<0.01 \\
{ }^{\dagger} \text { Magnesium DRI = } 130 \mathrm{mg} / \text { day }(4-8 \mathrm{y}) ; 240 \mathrm{mg} / \text { day }(9-13 \mathrm{y})(\mathrm{IOM}, 1997)\end{array}$} \\
\hline
\end{tabular}

Table 21. Vitamin D Content and Intake of Student Lunches From School or Home

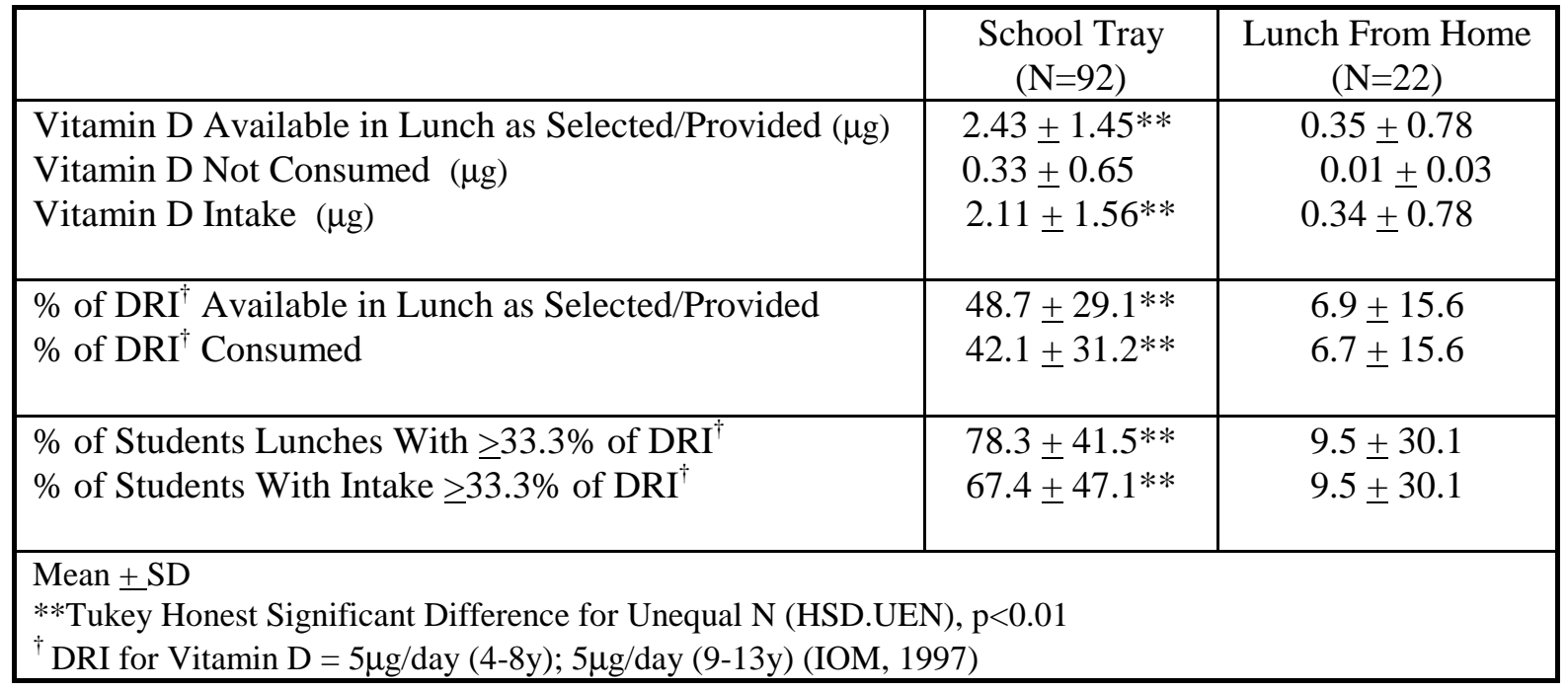


Table 22. Fluoride Content and Intake from Student Lunches

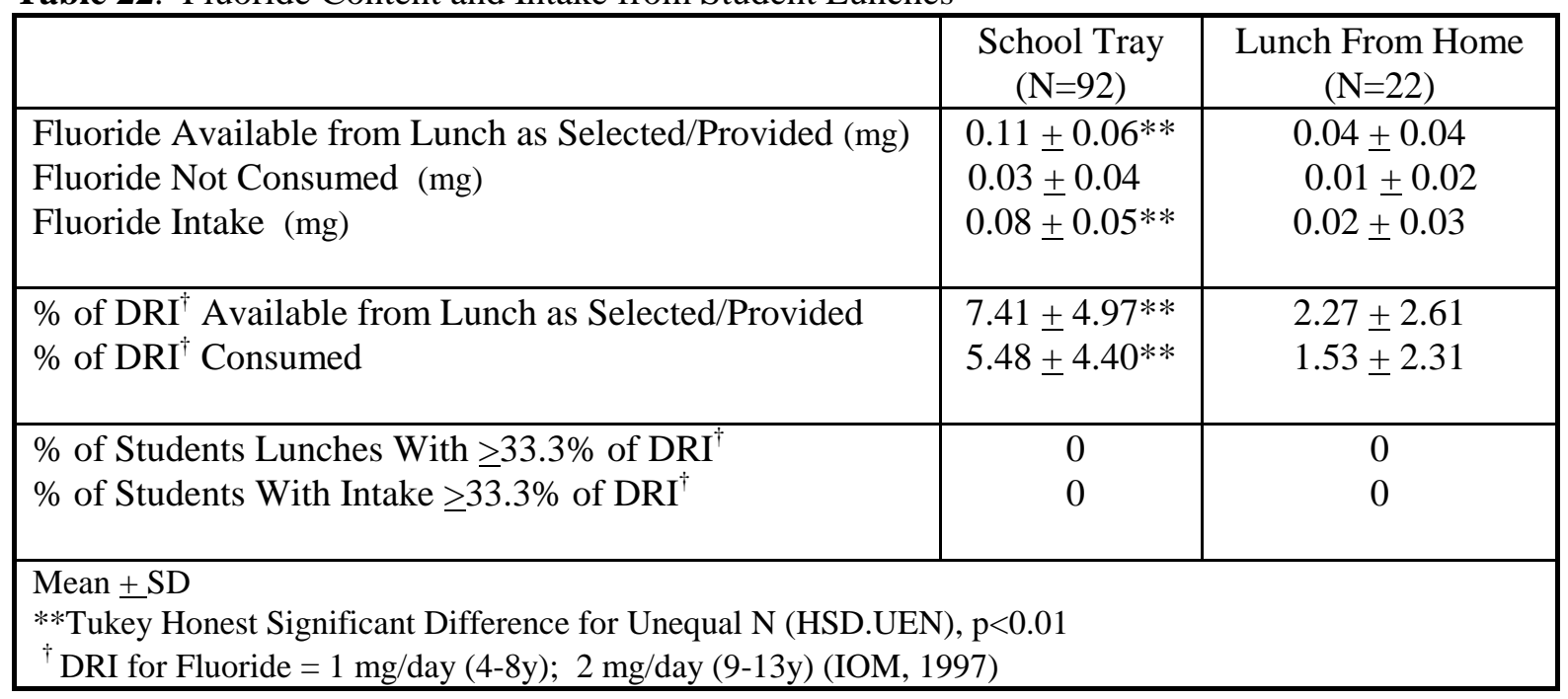

\section{$\underline{\text { Nutrients Associated with Cancer Prevention }}$}

Content and intake values of the dietary antioxidants vitamin $\mathrm{C}$ and vitamin $\mathrm{E}$ for both school and packed lunch participants are given in Table 23 and Table 24.

There was no significance indicated for differences in either content or intake of these two nutrients between the two types of lunches. Over half of school lunches met the DRI standard for content of vitamin $\mathrm{C}$ while less than half of packed lunches provided the recommended standard. The percentage of students with intakes meeting or exceeding the standard was approximately the same for both types of lunch.

Less than ten percent of both school lunches and packed lunches provided the onethird of DRI standard for vitamin E and the percentage of students with intake meeting or exceeding the standard was less than one percent for both groups. 
Table 23. Vitamin C Content and Intake of Student Lunches From School or Home

\begin{tabular}{|l|c|c|}
\hline & $\begin{array}{c}\text { School Tray } \\
(\mathrm{N}=92)\end{array}$ & $\begin{array}{c}\text { Lunch from Home } \\
(\mathrm{N}=22)\end{array}$ \\
\hline $\begin{array}{l}\text { Vitamin C Available in Lunch as Selected/Provided } \\
(\mathrm{mg})\end{array}$ & $\begin{array}{c}20 \pm 17 \\
5 \pm 6\end{array}$ & $9 \pm 48$ \\
$\begin{array}{l}\text { Vitamin C Not Consumed (mg) } \\
\text { Vitamin C Intake (mg) }\end{array}$ & $15 \pm 16$ & $25 \pm 37$ \\
\hline $\begin{array}{l}\text { \% of DRI Available in Lunch as Selected/Provided } \\
\% \text { of DRI Consumed }\end{array}$ & $57 \pm 53$ & $87 \pm 116$ \\
& $44 \pm 49$ & $65 \pm 92$ \\
\hline$\%$ of Student Lunches with $\geq 33.3 \%$ of DRI & \\
$\%$ of Students With Intake $\geq 33.3 \%$ of DRI & $41 \pm 50$ \\
\hline & $60 \pm 49$ & $36 \pm 50$ \\
\hline Mean \pm Std. Dev. & $40 \pm 50$ & \\
${ }^{\dagger}$ DRI for Vitamin C=25 mg (4-8y); 45 mg (9-13y) (IOM, 2000) & & \\
\hline
\end{tabular}

Table 24. Vitamin E Content and Intake of Student Lunches From School or Home

\begin{tabular}{|l|c|c|}
\hline & $\begin{array}{c}\text { School Tray } \\
(\mathrm{N}=92)\end{array}$ & $\begin{array}{c}\text { Lunch from Home } \\
(\mathrm{N}=22)\end{array}$ \\
\hline Vitamin E Available in Lunch as Selected/Provided (mg) & $1.65 \pm 0.72$ & $1.63 \pm 1.12$ \\
Vitamin E Not Consumed (mg) & $0.51 \pm 0.49$ & $0.33 \pm 0.52$ \\
Vitamin E Intake (mg) & $1.1 \pm 0.68$ & $1.31 \pm 0.95$ \\
\hline \% of DRI ${ }^{\dagger}$ Available in Lunch as Selected/Provided & $18.2 \pm 9.0$ & $15.9 \pm 10.7$ \\
$\%$ of DRI ${ }^{\dagger}$ Consumed & $12.7 \pm 8.4$ & $12.5 \pm 8.6$ \\
\hline$\%$ of Student Lunches with $\geq 33.3 \%$ of DRI \\
$\%$ of Students With Intake $\geq 33.3 \%$ of DRI & \\
\hline & $5.4 \pm 0.23$ & $9.1 \pm 0.29$ \\
\hline Mean \pm Std. Dev. & $1.1 \pm 10.4$ & 0 \\
\hline
\end{tabular}




\section{Nutrients Acting as Facilitators for Energy Release and Prevention of Developmental Disorders}

Data pertaining to content and intake of the energy-release nutrients in both lunch types are presented in Table $\mathbf{2 4}$ through Table 32.

Lunches provided at school and selected by students were significantly higher than lunches from home at $\mathrm{p}<0.01$ for riboflavin, vitamin $\mathrm{B}_{6}$, folate, vitamin $\mathrm{B}_{12}$, and pantothenic acid. Niacin content was also significantly higher in school lunches at $p<0.05$. Intake of vitamin $B_{12}$ and pantothenic acid were significantly higher at $\mathrm{p}<0.01$ with intakes of riboflavin, vitamin $\mathrm{B}_{6}$, and folate significantly higher in school lunch at $\mathrm{p}<0.05$. No significant differences were indicated for content or intake of thiamin or biotin between the two types of lunch.

Over seventy-five percent of both lunch types met or exceeded the one-third of DRI standards for content of thiamin, riboflavin, and niacin. The percentage of school lunches meeting or exceeding the standards for vitamin $\mathrm{B}_{6}$, vitamin $\mathrm{B}_{12}$, and pantothenic acid were significantly higher than school lunches at $\mathrm{p}<0.01$. Less than thirty percent of both types of lunch met or exceeded the DRI standards for folate and biotin content.

The percentage of students having intakes that met the recognized standards were significantly higher from school lunches for vitamin $\mathrm{B}_{6}$ at $\mathrm{p}<0.05$ and for vitamin $\mathrm{B}_{12}$ and pantothenic acid at $\mathrm{p}<0.01$. 
Table 25. Thiamin Content and Intake of Student Lunches From School or Home

\begin{tabular}{|c|c|c|}
\hline & $\begin{array}{c}\text { School Tray } \\
(\mathrm{N}=92)\end{array}$ & $\begin{array}{l}\text { Lunch from Home } \\
(\mathrm{N}=22)\end{array}$ \\
\hline Thiamin Available in Lunch as Selected/Provided (mg) & $0.48 \pm 0.15$ & $0.52 \pm 0.25$ \\
\hline Thiamin Not Consumed (mg) & $0.12 \pm 0.14$ & $0.09 \pm 0.10$ \\
\hline Thiamin Intake (mg) & $0.35 \pm 0.17$ & $0.43 \pm 0.26$ \\
\hline $\begin{array}{l}\% \text { of } \mathrm{DRI}^{\dagger} \text { Available in Lunch as Selected/Provided } \\
\% \text { of } \mathrm{DRI}^{\dagger} \text { Consumed }\end{array}$ & $\begin{array}{l}63 \pm 24 \\
47 \pm 24\end{array}$ & $\begin{array}{l}62 \pm 31 \\
51 \pm 30\end{array}$ \\
\hline $\begin{array}{l}\% \text { of Student Lunches with } \geq 33.3 \% \text { of DRI } \\
\% \text { of Students With Intake } \geq 33.3 \% \text { of DRI }\end{array}$ & $\begin{array}{l}91 \pm 28 \\
74 \pm 44\end{array}$ & $\begin{array}{l}82 \pm 40 \\
68 \pm 48\end{array}$ \\
\hline & & \\
\hline
\end{tabular}

Table 26. Riboflavin Content and Intake of Student Lunches From School or Home

\begin{tabular}{|c|c|c|}
\hline & $\begin{array}{l}\text { School Tray } \\
(\mathrm{N}=92)\end{array}$ & $\begin{array}{l}\text { Lunch from Home } \\
\qquad(\mathrm{N}=22)\end{array}$ \\
\hline Riboflavin Available in Lunch as Selected/Provided (mg) & $0.85 \pm 0.31 * *$ & $0.50 \pm 0.29$ \\
\hline Riboflavin Not Consumed (mg) & $0.20 \pm 0.21 *$ & $0.07 \pm 0.10$ \\
\hline Riboflavin Intake (mg) & $0.65 \pm 0.36 *$ & $0.42 \pm 0.28$ \\
\hline $\begin{array}{l}\% \text { of } \mathrm{DRI}^{\dagger} \text { Available in Lunch as Selected/Provided } \\
\% \text { of } \mathrm{DRI}^{\dagger} \text { Consumed }\end{array}$ & $\begin{array}{c}113 \pm 49 * * \\
86 \pm 51 *\end{array}$ & $\begin{array}{l}60 \pm 38 \\
50 \pm 35\end{array}$ \\
\hline $\begin{array}{l}\% \text { of Student Lunches with } \geq 33.3 \% \text { of } \mathrm{DRI}^{\dagger} \\
\% \text { of Students With Intake } \geq 33.3 \% \text { of } \mathrm{DRI}^{\dagger}\end{array}$ & $\begin{array}{l}97 \pm 18 * \\
85 \pm 36\end{array}$ & $\begin{array}{l}77 \pm 43 \\
64 \pm 49\end{array}$ \\
\hline \multicolumn{3}{|c|}{$\begin{array}{l}\text { Mean } \pm \text { Std. Dev. } \\
* \text { Tukey Honest Significant Difference for Unequal N (HSD.UEN), } \mathrm{p}<0.05 \\
* * \text { HSD.UEN, }<0.01 \\
{ }^{\dagger} \text { DRI for Riboflavin= } 0.6 \mathrm{mg}(4-8 \mathrm{y}) ; 0.9 \mathrm{mg}(9-13 \mathrm{y})(\mathrm{IOM}, 1998)\end{array}$} \\
\hline
\end{tabular}


Table 27. Niacin Content and Intake of Student Lunches From School or Home

\begin{tabular}{|c|c|c|}
\hline & $\begin{array}{c}\text { School Tray } \\
(\mathrm{N}=92)\end{array}$ & $\begin{array}{l}\text { Lunch from Home } \\
\qquad(\mathrm{N}=22)\end{array}$ \\
\hline Niacin Available in Lunch as Selected/Provided (mg) & $7.2 \pm 2.6$ & $6.0 \pm 3.0$ \\
\hline Niacin Not Consumed (mg) & $2.7 \pm 2.5 * *$ & $0.6 \pm 0.7$ \\
\hline Niacin Intake (mg) & $4.5 \pm 2.4$ & $5.4 \pm 3.1$ \\
\hline $\begin{array}{l}\% \text { of } \mathrm{DRI}^{\dagger} \text { Available in Lunch as Selected/Provided } \\
\% \text { of } \mathrm{DRI}^{\dagger} \text { Consumed }\end{array}$ & $\begin{array}{l}71 \pm 31 \\
44 \pm 26^{*}\end{array}$ & $\begin{array}{l}53 \pm 26 \\
48 \pm 26\end{array}$ \\
\hline $\begin{array}{l}\% \text { of Student Lunches with } \geq 33.3 \% \text { of } \mathrm{DRI}^{\dagger} \\
\% \text { of Students With Intake } \geq 33.3 \% \text { of DRI }\end{array}$ & $\begin{array}{l}89 \pm 31 \\
63 \pm 49\end{array}$ & $\begin{array}{l}77 \pm 43 \\
73 \pm 46\end{array}$ \\
\hline \multicolumn{3}{|c|}{$\begin{array}{l}\text { Mean } \pm \text { Std. Dev. } \\
* \text { Tukey Honest Significant Difference for Unequal N (HSD.UEN), } \mathrm{p}<0.05 \\
* * \text { HSD.UEN, }<0.01 \\
{ }^{\dagger} \text { DRI for Niacin }=8 \mathrm{mg}(4-8 \mathrm{y}) ; 12 \mathrm{mg}(9-13 \mathrm{y})(\mathrm{IOM}, 1998)\end{array}$} \\
\hline
\end{tabular}

Table 28. Vitamin $B_{6}$ Content and Intake of Student Lunches From School or Home

\begin{tabular}{|c|c|c|}
\hline & $\begin{array}{l}\text { School Tray } \\
(\mathrm{N}=92)\end{array}$ & $\begin{array}{c}\text { Lunch from } \\
\text { Home }(\mathrm{N}=22)\end{array}$ \\
\hline Vitamin $B_{6}$ Available in Lunch as Selected/Provided (mg) & $0.46 \pm 0.12 * *$ & $0.25 \pm 0.21$ \\
\hline Vitamin $\mathrm{B}_{6}$ Not Consumed (mg) & $0.15 \pm 0.13 * *$ & $0.03 \pm 0.05$ \\
\hline Vitamin $B_{6}$ Intake (mg) & $0.32 \pm 0.14^{*}$ & $0.22 \pm 0.22$ \\
\hline$\%$ of DRI Available in Lunch as Selected/Provided & $59 \pm 23 * *$ & $27 \pm 22$ \\
\hline$\%$ of DRI Consumed & $40 \pm 21 *$ & $23 \pm 22$ \\
\hline$\%$ of Student Lunches with $\geq 33.3 \%$ of $\mathrm{DRI}^{\dagger}$ & $89 \pm 31 * *$ & $19 \pm 40$ \\
\hline$\%$ of Students With Intake $\geq 33.3 \%$ of $\mathrm{DRI}^{\dagger}$ & $57 \pm 50 *$ & $19 \pm 40$ \\
\hline \multicolumn{3}{|c|}{$\begin{array}{l}\text { Mean } \pm \text { Std. Dev. } \\
* \text { Tukey Honest Significant Difference for Unequal N (HSD.UEN), } p<0.05 \\
* * \text { HSD.UEN, }<<0.01 \\
{ }^{\dagger} \text { DRI for Vitamin } B_{6}=0.6 \mathrm{mg}(4-8 \mathrm{y}) ; 1.0 \mathrm{mg}(9-13 \mathrm{y})(\mathrm{IOM}, 1998)\end{array}$} \\
\hline
\end{tabular}


Table 29. Folate Content and Intake of Student Lunches From School or Home

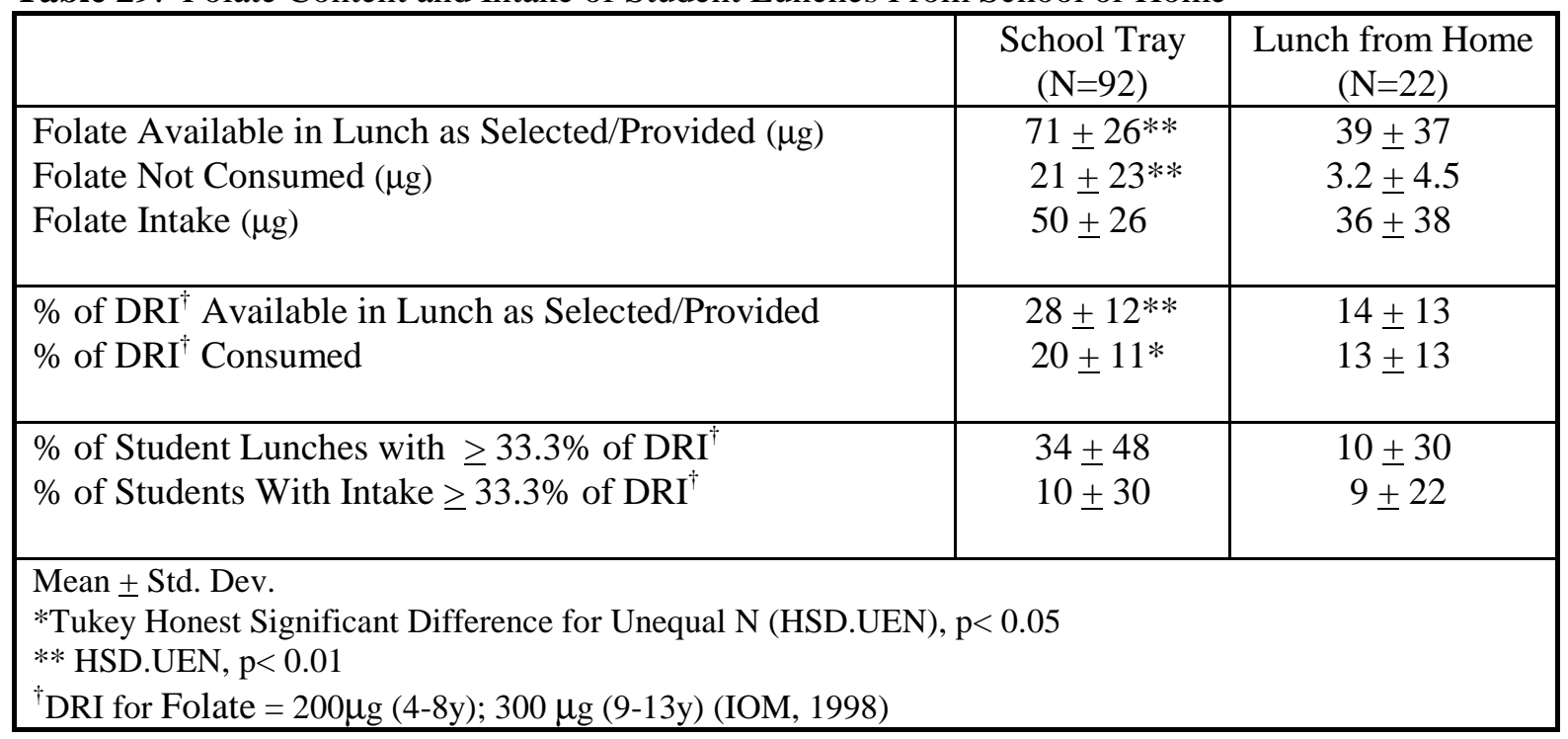

Table 30. Vitamin $B_{12}$ Content and Intake of Student Lunches From School or Home

\begin{tabular}{|c|c|c|}
\hline & $\begin{array}{l}\text { School Tray } \\
(\mathrm{N}=92)\end{array}$ & $\begin{array}{l}\text { Lunch from Home } \\
\qquad(\mathrm{N}=22)\end{array}$ \\
\hline Vitamin $B_{12}$ Available in Lunch as Selected/Provided $(\mu \mathrm{g})$ & $1.63 \pm 0.62 * *$ & $0.61 \pm 0.50$ \\
\hline Vitamin $\mathrm{B}_{12}$ Not Consumed $(\mu \mathrm{g})$ & $0.45 \pm 0.49 * *$ & $0.05 \pm 0.14$ \\
\hline Vitamin $B_{12}$ Intake $(\mu \mathrm{g})$ & $1.18 \pm 0.68 * *$ & $0.56 \pm 0.51$ \\
\hline $\begin{array}{l}\% \text { of DRI }{ }^{\dagger} \text { Available in Lunch as Selected/Provided } \\
\% \text { of } \mathrm{DRI}^{\dagger} \text { Consumed }\end{array}$ & $\begin{aligned} 108 & \pm 45^{* *} \\
78 & \pm 47 * *\end{aligned}$ & $\begin{array}{l}38 \pm 33 \\
34 \pm 33\end{array}$ \\
\hline $\begin{array}{l}\% \text { of Student Lunches with } \geq 33.3 \% \text { of DRI } \\
\% \text { of Students With Intake } \geq 33.3 \% \text { of } \mathrm{DRI}^{\dagger}\end{array}$ & $\begin{array}{l}95 \pm 23^{* *} \\
83 \pm 38^{* *}\end{array}$ & $\begin{array}{l}52 \pm 51 \\
43 \pm 51\end{array}$ \\
\hline \multicolumn{3}{|c|}{$\begin{array}{l}\text { Mean } \pm \text { Std. Dev. } \\
* * \text { Tukey Honest Significant Difference for Unequal N (HSD.UEN), } \mathrm{p}<0.01 \\
{ }^{\dagger} \text { DRI for Vitamin } \mathrm{B}_{12}=1.2 \mu \mathrm{g}(4-8 \mathrm{y}) ; 1.8 \mu \mathrm{g}(9-13 \mathrm{y})(\text { IOM, 1998) }\end{array}$} \\
\hline
\end{tabular}


Table 31. Pantothenic Acid Content and Intake of Student Lunches From School or Home

\begin{tabular}{|c|c|c|}
\hline & $\begin{array}{l}\text { School Tray } \\
(\mathrm{N}=92)\end{array}$ & $\begin{array}{c}\text { Lunch from } \\
\text { Home }(\mathrm{N}=22)\end{array}$ \\
\hline $\begin{array}{l}\text { Pantothenic Acid Available in Lunch as Selected/Provided } \\
\text { (mg) } \\
\text { Pantothenic Acid Not Consumed (mg) } \\
\text { Pantothenic Acid Intake (mg) }\end{array}$ & $\begin{array}{l}1.98 \pm 0.96 * * \\
0.60 \pm 0.74 * \\
1.38 \pm 0.72 * *\end{array}$ & $\begin{array}{l}0.65 \pm 0.45 \\
0.07 \pm 0.09 \\
0.59 \pm 0.47\end{array}$ \\
\hline $\begin{array}{l}\% \text { of DRI }{ }^{\dagger} \text { Available in Lunch as Selected/Provided } \\
\% \text { of } \mathrm{DRI}^{\dagger} \text { Consumed }\end{array}$ & $\begin{array}{l}57 \pm 31 * * \\
39 \pm 22 * *\end{array}$ & $\begin{array}{l}17 \pm 13 \\
16 \pm 13\end{array}$ \\
\hline $\begin{array}{l}\% \text { of Student Lunches with } \geq 33.3 \% \text { of DRI } \\
\% \text { of Students With Intake } \geq 33.3 \% \text { of } \mathrm{DRI}^{\dagger}\end{array}$ & $\begin{array}{l}85 \pm 36^{* *} \\
55 \pm 50^{* *}\end{array}$ & $\begin{array}{l}11 \pm 32 \\
11 \pm 32\end{array}$ \\
\hline \multicolumn{3}{|c|}{$\begin{array}{l}\text { Mean } \pm \text { Std. Dev. } \\
* \text { Tukey Honest Significant Difference for Unequal N (HSD.UEN), } \mathrm{p}<0.05 \\
\text { ** HSD.UEN, }<<0.01 \\
{ }^{\dagger} \text { DRI for Pantothenic Acid = } 3 \mathrm{mg}(4-8 \mathrm{y}) ; 4 \mathrm{mg}(9-13 \mathrm{y})(\mathrm{IOM}, 1998)\end{array}$} \\
\hline
\end{tabular}

Table 32. Biotin Content and Intake of Student Lunches From School or Home

\begin{tabular}{|l|c|c|}
\hline & $\begin{array}{c}\text { School Tray } \\
(\mathrm{N}=92)\end{array}$ & $\begin{array}{c}\text { Lunch from Home } \\
(\mathrm{N}=22)\end{array}$ \\
\hline Biotin Available in Lunch as Selected/Provided $(\mu \mathrm{g})$ & $3.39 \pm 2.67$ & $3.71 \pm 2.56$ \\
Biotin Not Consumed $(\mu \mathrm{g})$ & $0.94 \pm 1.52$ & $0.72 \pm 1.39$ \\
Biotin Intake $(\mu \mathrm{g})$ & $2.46 \pm 2.42$ & $2.99 \pm 2.71$ \\
\hline \% of DRI ${ }^{\dagger}$ Available in Lunch as Selected/Provided & $21 \pm 17$ & $20 \pm 14$ \\
$\%$ of DRI ${ }^{\dagger}$ Consumed & $15 \pm 14$ & $17 \pm 15$ \\
\hline \% of Student Lunches with $\geq 33.3 \%$ of DRI ${ }^{\dagger}$ & & $11 \pm 32$ \\
$\%$ of Students With Intake $\geq 33.3 \%$ of DRI & $11 \pm 32$ \\
\hline Mean \pm Std. Dev. & $24 \pm 43$ & \\
\hline DRI for Biotin $=12 \mu \mathrm{g}(4-8 \mathrm{y}) ; 20 \mu \mathrm{g}(9-13 \mathrm{y})$ & $13 \pm 34$ & \\
\hline
\end{tabular}




\section{CHAPTER V}

\section{DISCUSSION}

This discussion will first address concerns with overall nutrient content and intake between school and packed lunches. Second, the nutrient categories presented previously in this paper and their specific health implications will be compared between the two lunch types. Finally, the nutrient value of the school lunches and packed lunches will be compared to current school lunch standards as mandated by the United States Department of Agriculture (1995), and the West Virginia Department of Education (1994).

\section{Comparison of Overall Nutrient Content and Intake Between School and Packed}

\section{Lunches}

The current study found that students eating school lunch wasted more food overall than those students who brought lunches from home. Devaney et al. (1995), determined that National School Lunch Participants wasted ten to fifteen percent of the nutrients they were served. These similar findings may be attributed to the fact that students bringing lunch from home are more likely to be provided with foods of their choice than school lunch participants. A typical packed lunch in the current study consisted of a meat sandwich, some type of snack chips, a high sugar food (i.e. a snack cake, fruit snack, pudding, or fruit rollup), a high sugar fruit beverage or soda, and an occasional fruit or vegetable. Pepperoni rolls, (portions of pepperoni baked into bread dough that are common to this region of West Virginia), were the most frequently packed sandwich choice. Packed lunches typically were deficient in most dairy products with the exception of cheese sticks or an occasional fruit 
yogurt. Milk was available for purchase to students who brought lunches from home, but there were no packed lunch students in this study who took advantage of this option. Gordon \& McKinney (1995), noted similar lunch choices among non-participants of the school lunch program who were much more likely to consume cakes, cookies, salty snacks, and sweets at lunch and were likely to have higher vitamin $\mathrm{C}$ intake recorded than school lunch participants due to frequent consumption of fruitades fortified with vitamin $\mathrm{C}$.

In spite of the larger amount of food discarded from school trays, the school lunches provided higher nutrient intake overall than packed lunches. Ho et al. (1991), interpreted similar findings among school and packed lunches. The previous study, however, did not evaluate values for vitamin $\mathrm{E}$, the bone-related nutrients, or the energy-facilitating nutrients, and plate waste was the predominant method of measurement over actual weighing.

\section{Comparison of Nutrient Categories Among School and Packed Lunches}

Energy and Macronutrients. School and packed lunches provided similar amounts of total energy, energy from carbohydrate, energy from fat and energy from saturated fat. Previous studies by Ho et al.(1991) and Devaney, Gordon, \& Burghart (1995), determined that school lunches contained higher amounts of total fat and saturated fat than packed lunches. While school lunches and packed lunches in the current study slightly exceeded recommendations for content of total fat and saturated fat, intake of these energy sources fell close to the recommendations for both types of lunch. Protein content of school lunches in the current study exceeded the total daily protein RDA by $12 \%$. Devaney et al. (1995), using 24-hour dietary recall, determined that children ages six to ten consumed $101 \%$ of the total RDA of protein from the noon meal. 
The current study also evaluated total sugar content and intake from the two lunch options. Total sugar in this case consisted of all dissacharides, which include the naturally occurring sugars of milk and fruit. Sugar has been researched in relationship to obesity, diabetes, and heart disease. Hill and Prentice (1995), concluded that sugar may contribute to obesity, but is not the sole cause. High sugar beverages and snack items contributed to the excess sugar content of packed lunches. Much of the sugar contributed to school lunch was provided naturally in milk and juice and some from ice cream, gelatin and other dessert options.

Nutrients and Fiber Related to USDA and WVBOE School Lunch Standards. Prior research has indicated the importance of reducing sodium content in school lunches (Ho et al., 1991) and (Devaney, Gordon \& Burghardt, 1995). Data from the current study indicated that $40 \%$ of school lunches as selected by students provided within the recommendation of $\leq 1100 \mathrm{mg} / \mathrm{meal}$ and that $77 \%$ of students eating school lunch had intakes meeting this WVBOE standard. The mean percentage of packed lunches providing sodium values within the recommendation was $50 \%$ but students with packed lunch intakes meeting the goal were $55 \%$. Although school lunches in this study contained sodium levels that exceeded recommendations, intake from both types of lunch fell within recommended levels. It should be noted that the standard used in this study $(\leq 1100 \mathrm{mg})$, based on WVBOE policy, is 200$300 \mathrm{mg}$. above the standards used by the previous researchers.

School lunches were the only option providing appropriate levels of dietary fiber according to the WVBOE standard, but intake from school lunch was not significantly higher than packed lunch. According to Williams (1995), children above the age of two years should consume dietary fiber in amounts that equal their age $+5 \mathrm{~g} / \mathrm{day}$. The range of 
appropriate daily intake for the ages involved in this study would be $12-15 \mathrm{~g} / \mathrm{day}$. For the noon meal, one-third of this amount would be 4-5 g. While these values represent minimum recommendations, the WVBOE standard may need to be reevaluated for elementary age students. Fiber is provided in school lunch by adding a percentage of whole grain flour to all bread products and by offering fresh fruits and vegetables. Packed lunches for the most part, contained refined bread items and few raw fruits or vegetables.

No significant difference was indicated between packed lunch and school lunch for content or intake of iron. School lunch and packed lunch both provided a mean percentage of $40 \%$ of the RDA for iron. Only $35 \%$ of students eating school lunch had intakes meeting the standard while $50 \%$ of students eating packed lunch met or exceeded recommended intake. As noted previously, school lunches were higher in protein but intakes of protein from both types of lunch were similar. The iron content of both lunch types was most likely obtained from meat sources and from iron fortified bread products.

Both school lunches and those brought from home provided Vitamin A levels that exceeded the one-third of RDA standard. Twice as many students who ate school lunch, however, consumed above the RDA for vitamin A than those students who ate lunch brought from home. Raw fruits and vegetables, including carrots, were offered on most days in school lunch resulting in the higher intakes of vitamin A among this group. Milk and cheese also contributed to school lunch vitamin A content. Packed lunches most likely derived the majority of their vitamin A from fortified foods and an occasional raw fruit or vegetable.

Students with intakes meeting or exceeding the DRI for zinc were $51 \%$ for school lunches and $10 \%$ for packed lunches. Since protein-containing foods are the highest 
contributors of zinc, protein excesses as indicated in school lunch provided optimal levels of zinc in this study.

Nutrients Related to Osteoporosis and Bone Integrity. It was noted in this study that mean intake of milk, yogurt, and ice cream from school lunch was $234 \mathrm{~g} /$ day while mean intake of the same foods from packed lunch was only $44 \mathrm{~g} / \mathrm{day},(\mathrm{p}<0.01)$; calcium intake from school lunch was $346 \mathrm{mg} /$ day vs. calcium intake from packed lunch of 204mg/day, $(\mathrm{p}<0.05)$. Lack of milk and other dairy foods in packed lunches may be one of the major reasons for differences among content and intake of the bone-related nutrients. Johnston, Miller, Slemenda, Reister, Hui, Christian, and Peacock (1992), determined that supplementation of children with calcium levels above control groups led to increased bone density which is critical for attaining peak bone mass and offering protection from osteoporosis. As noted by Fleming and Heimback (1994), a diet inadequate in dairy products may be inadequate in calcium, vitamin $\mathrm{A}$, folate, riboflavin, vitamin $\mathrm{B}_{6}$, magnesium, and potassium.

Based upon other data from this study, almost half of students eating school lunches met or exceeded the one-third of DRI standard for intake of calcium while less than $10 \%$ of students eating packed lunches met or exceeded the standard. Devaney et al. (1995), indicated that children ages 6-10 were meeting or exceeding the recommended amounts of calcium, phosphorus, and magnesium from the lunch meal. This prior research was based on the RDA for calcium which has since been increased for this age group as a result of the new DRI's. It should be noted that the difference in calcium between the two lunch types may well have been higher, but the schools in Marion County provide juice as an optional beverage and this was often selected over milk. 
Students with intakes from school lunch that met or exceeded the one-third DRI standard for phosphorus, magnesium, and zinc were $62 \%, 40 \%$, and $67 \%$ respectively. Less than $10 \%$ of students eating packed lunches had intakes that met or exceeded the standard for these three nutrients. While fluoride levels were determined in this study along with other bone-related nutrients, it is known that the nation's primary source of fluoride is not from food but from fluoridated water.

Nutrients Associated with Cancer Prevention. The antioxidant nutrients are noted in current research for their potential role in cancer prevention. Byers and Perry (1992), confirm a link between vitamin- $\mathrm{C}$ rich foods and reduced cancer risk and between vitamin $\mathrm{E}$ and reduced risks of coronary heart disease. The study did not, however, establish a correlation between intake of vitamin $\mathrm{E}$ and $\mathrm{C}$ supplements and reduced cancer risk. Devaney et al. (1995), determined adequate intakes of vitamin C from school lunch. In the current study, there were no significant differences between school and packed lunches in relation to content and intake of the antioxidant nutrients vitamin $\mathrm{E}$ and vitamin $\mathrm{C}$. Both types of lunches provided adequate amounts of vitamin $\mathrm{C}$ in relation to the one-third of DRI standard but neither lunch type provided at least the minimum standard for vitamin E. Mean intakes of vitamin $\mathrm{C}$ between both types of lunches also met the DRI standard but the mean intake of vitamin $\mathrm{E}$ for both groups was only $12 \%$ of the DRI. The supplementation of vitamin $\mathrm{C}$ in fruit beverages provided in most packed meals account for adequate intakes from this lunch type.

Nutrients Acting as Facilitators for Energy Release and Prevention of Developmental Diseases. Devaney, Gordon, \& Burghardt (1995), determined from diet recall of $~ 3350$ students nationwide that all NSLP participants met intakes of thiamin, riboflavin, niacin, $\mathrm{B}_{6}$, 
folate and $B_{12}$ at mean values exceeding $33 \%$ of the RDA. The study by Ho et al. (1991), did not look at the B vitamin content of lunches evaluated.

Data collected during this study found that adequate amounts of thiamin, riboflavin, niacin, and $\mathrm{B}_{12}$ in relation to one-third of the DRI standard were available and consumed in school lunches and packed lunches both. Vitamin $\mathrm{B}_{6}$ and pantothenic acid were supplied and consumed in adequate amounts as one-third of the DRI percentage in school lunch but not in packed lunches. Folate and biotin were neither provided, nor consumed, in adequate amounts in either type of lunch but their availability in school lunch was higher than in packed lunches. The U.S. began fortifying all enriched flour with folate as of January 1, 1998 (American Institute for Cancer Research, 2000). Since both types of lunch provided several folate-enriched food sources, the nutrient analysis database used in this study may not have been adequately updated for current folate values. Significant difference was shown at $\mathrm{p}<0.01$ for riboflavin, vitamin $\mathrm{B}_{6}$, folate, vitamin $\mathrm{B}_{12}$, and pantothenic acid available in the types of lunches. Significance was also indicated for differences in intake of vitamin $\mathrm{B}_{12}$ and pantothenic acid at $\mathrm{p}<0.01$ and for riboflavin, vitamin $\mathrm{B}_{6}$, and folate at $\mathrm{p}<0.05$. Low levels of these nutrients in packed lunches as opposed to school lunches can be attributed to food selections that were less whole, heavily processed, and lower in protein.

\section{Nutrient Value of School and Packed Lunches as Compared to National and State}

\section{$\underline{\text { School Lunch Standards }}$}

School lunches, as selected provided adequate amounts of energy, protein, iron, vitamin A, calcium, and vitamin C. Energy provided as fat and as saturated fat were slightly 
high in the school lunches and sodium was available in excess. Dietary fiber was provided in adequate amounts as selected.

Intake of total energy, iron, and dietary fiber from school lunch did not meet recommended standards but adequate amounts of protein, vitamin $\mathrm{A}$, vitamin $\mathrm{C}$, and calcium were obtained. Iron intake fell below recommendations and energy consumed as saturated fat was still in excess. Sodium, although provided in excess, was consumed within recommended amounts. Dietary fiber was not consumed in amounts to meet the WVBOE standard.

Packed lunches met the standards defined by USDA and the WVBOE for content and intake of total energy, protein, iron, vitamin A and vitamin C. Proportion of energy distributed as total fat was both provided and consumed in excess but saturated fat as a proportion of total energy was appropriate for both content and intake in packed lunches. Sodium levels were also within recommendations. Packed lunches were inadequate in calcium and dietary fiber for both content and intake. 


\section{CHAPTER VI}

\section{SUMMARY}

The dietary intake of children is an important issue in current research because of recent shifts in the last two decades from concerns of inadequate nutrient intake to concerns of excesses of particular nutrients that may lead to or prevent diet-related illnesses. (Munoz, Krebs-Smith, Ballard-Barbash, \& Cleveland, 1997). Excesses of energy intake and recent trends in childhood adiposity increase risks for conditions such as diabetes, coronary heart disease, cancer, stroke, and osteoporosis (Public Health Service, 1998). Recent federal and state legislation for school lunch programs has mandated adherence to the Recommended Dietary Allowances and the Dietary Guidelines for Americans in regard to specific nutrients and dietary fiber (US Department of Agriculture, 1995 \& WV Board of Education, 1994). Since many of these standards were not mandated until the 1998-99 school year, previous research cited in this study evaluated programs that did not fall under compliance with current mandates. In addition, recent work by the Institute of Medicine to develop the Dietary Reference Intakes have refined nutrient intake standards, providing better estimates for determining individual needs as well as those of groups.

\section{$\underline{\text { Summary of Findings }}$}

The data collected and analyzed in this study were adequate to meet the goal of the original research objectives defined by three hypotheses. The first hypothesis stated that there is no difference in the nutrient content of school and packed lunches. Statistics determined a strong difference in nutrient content between school and packed lunches for 
energy available as protein and sugar, dietary fiber, vitamin A, zinc, the bone-related nutrients (calcium, phosphorus, magnesium, vitamin D, and fluoride), and the energyfacilitating nutrients (riboflavin, niacin, $\mathrm{B}_{6}$, folate, $\mathrm{B}_{12}$, and pantothenic acid). All of these nutrients were available in larger quantities in school lunch rather than packed lunches with the exception of energy available as sugar, which was higher in packed lunches. Because of the significant differences in nutritive value between the two types of lunches, hypothesis one must be rejected.

Hypothesis two states that there is no difference in the nutrient intake of school lunches and packed lunches as consumed. Nutrient intakes varied significantly between school and packed lunches for energy consumed as sugar, zinc, the bone-related nutrients (calcium, phosphorus, magnesium, vitamin D, and fluoride), and the energy-facilitating nutrients (riboflavin, $\mathrm{B}_{6}, \mathrm{~B}_{12}$, and pantothenic acid). Because significant differences in these nutrient values between school and packed lunches were determined at $\mathrm{p}<0.01$ and $\mathrm{p}<0.05$ levels, hypothesis two must be rejected also.

Hypothesis three states that there is no difference between school lunches and packed lunches in relation to current RDA, DRI and Dietary Guidelines for Americans. Adequacy in meeting the defined nutrient standards was determined to be significant between the two types of lunches in regard to meal content of energy available as sugar and protein, percentage of RDA/DRI available for dietary fiber, vitamin A, zinc, the bone-related nutrients (calcium, phosphorus, magnesium, vitamin D and fluoride), and the energy-facilitating nutrients (riboflavin, niacin, $\mathrm{B}_{6}$, folate, $\mathrm{B}_{12}$, and pantothenic acid). Adequacy of intake in meeting the defined nutrient standards was significantly different between types of lunches for energy consumed as sugar, zinc, the bone-related nutrients (calcium, phosphorus, 
magnesium, vitamin $\mathrm{D}$, and fluoride), and the energy-facilitating nutrients (riboflavin, $\mathrm{B}_{6}$, folate, $\mathrm{B}_{12}$, and pantothenic acid). Therefore, hypothesis three is rejected as well.

The findings of this study allow us to reject each of the three null hypotheses by indications of significant differences between both nutrient content and intake of the two types of lunches and by the significant differences determined between the two types of lunches in meeting or exceeding the defined nutrient standards.

Conclusion: It is concluded that nutrient content of school lunches in this study was adequate based on federal and state guidelines, however, improvement is needed in assuring that intake from this type of lunch is also adequate. Packed lunches, overall, were inferior to school lunch in nutrient content and nutrient intake. Further, the findings suggest that milk and other dairy foods high in calcium and other bone-related nutrients would significantly improve the overall nutrient status of packed lunches.

\section{$\underline{\text { Implications and Applications for Further Research }}$}

Recent developments and updates in nutrient standards have occurred during the course of this study. The committees working to update nutrient values with more refined Dietary Reference Intakes have completed reports for a large percentage of the nutrients but recent release of the fourth DRI report and anticipation of a future report leave the researcher a wide realm of options for evaluating this current data in relationship to newly defined standards which will be available in the future. 


\section{Limitations of the Research}

Due to the limited number of parental consents granted for students who normally eat packed lunch, the data from this study provided limitations in statistical analysis based on the variance between the number of packed lunches $(n=22)$ and the number of school lunches $(n=92)$. Another limitation concerning the sample group was their distribution by age and gender. It was originally planned that the subjects would be randomly selected based on both gender and age. When a limited number of consents were returned, it was necessary to use all students in the data collection whose parents consented to their participation and who assented themselves to be a part of the study group. All of these factors provided limitations in evaluating nutrient content among different age or gender groups.

\section{Implications of the Study}

The implications of this study suggested that school lunches as selected and consumed were adequate according to USDA and WVBOE standards and were higher in nutrient density among most nutrients than packed lunches. Exceptions to this included vitamin $\mathrm{C}$ content and intake, iron intake, total energy content and intake, percentage of energy as total fat provided and consumed, and percentage of energy as sugar provided and consumed. Nutrient components of concern with school lunches were deficient overall energy intake, protein content that exceeded the total daily RDA, and excesses of total fat and saturated fat in both content and intake.

Of particular concern in this study was the difference between the types of lunch in regard to content and intake of the bone-related nutrients. These specific nutrients are critical 
for growth and the development of bone integrity, which may reduce future risks for osteoporosis. School lunches contained significantly more of these nutrients than packed lunches because they provided more dairy foods. Only school lunch provided adequate amounts of the dietary fiber noted for its potential in prevention of certain types of cancer, however intakes of dietary fiber from both school and packed lunches were below the WVDE standards of $6 \mathrm{~g}$. for the lunch meal.

While USDA guidelines for school lunches require only a one-week or one-month average to meet the recommended standards, this study looked at daily meal contents and intakes from those meals. The offer versus serve program provides students with the option of selecting a meal that may not meet US and state recommendations even though it was planned to do so.

School lunch is an important source of nutrients for elementary students in Marion County where free and reduced lunches are provided to almost half of the student population. Furthermore, school lunch as consumed either provided greater amounts of nutrients $(\mathrm{p}<0.01$ and $\mathrm{p}<0.05$ ) or was comparable to packed lunch in some nutrient contents. Parents need to be reminded of the economic savings that can be provided with school lunch. The average statewide cost for a regular-price lunch is $\$ 1.00$ and the average reduced-price meal is $\$ 0.40$ (West Virginia Department of Education, 2001). Packed lunches, with their convenience food items well exceed these costs.

School lunch standards provide the basis for well-balanced nutrient dense meals but student choices are the key to diets that meet recommended lunch standards. Educators and parents are the primary link in providing students with the nutrition knowledge to make food choices that are more nutrient dense and which offer better protection from obesity and the 
diet-related diseases that accompany poor nutrition. Nutrition education options may include: (i) teaching students to make adequate and wiser food choices, (ii) providing parents with information on the health benefits as well as the economic savings from school lunch, and (iii) providing educators with resources to instruct students on selection of healthy food choices, the importance of adequate energy and nutrient intake, and the health risks associated with poor nutrition over time. 


\section{REFERENCES}

Acculab. (2000). Digital Scale, VI-2400. Capacity: 2400g./Readability: 0.1g.

American Institute for Cancer Research. (2000). Folate May Offer Protection. American Institute for Cancer Research Newsletter, Summer 2000:5.

Barrett, S. (1997). Doing the DRIs, A no-nonsense guide to the nation's new nutritional yardsticks. Nutrition Forum. Amherst, NY: Prometheus Books.

Birch, L.L. (1999). Development of Food Preferences. Annual Reviews Nutrition. 19:41-62.

Borrud, L., Enns, C.W., Mickle, S. (1997). What we eat: USDA surveys food consumption changes. Nutrition Week. Community Nutrition Institute,4-5.

Bryant, R.J., Cadogan, J., Weaver, M. (1999). The New Dietary Reference Intakes for Calcium: Implications for Osteoporosis. Journal of the American College of Nutrition, 18(5):406S$412 \mathrm{~S}$.

Burghardt, J.A. \& Devaney, B.L. (1995). Background of the School Nutrition Dietary Assessment Study. American Journal of Clinical Nutrition, 61(suppl):178S-81S.

Burghardt, J.A., Gordon, A.R., Devaney, B.L. (1995). The school nutrition dietary assessment study: Summary and discussion. American Journal of Clinical Nutrition, 61(suppl):252S-257S.

Byers, T. Perry, G. (1992). Dietary carotenes, vitamin C and vitamin E as protective antioxidants in human cancers. Annual Reviews in Nutrition,12:139-159.

Centers for Disease Control and Prevention. (1997). Youth Risk Behavior Surveillance-United States. Morbidity and Mortality Weekly Report (MMWR) 1998;47(SS-3).

Devaney, B.L., Gordon, A.R., Burghardt, J.A. (1995). Dietary intakes of students. American Journal of Clinical Nutrition, 61(suppl):205S-12S.

Dwyer, J. (1995). The School Nutrition Dietary Assessment Study. American Journal of Clinical Nutrition, 61(suppl):173S-7S.

First Data Bank, Inc. (1998). Nutritionist V. Version 2.1.1. CA, San Bruno: Hearst Corp.

Food and Nutrition Service, US Department of Agriculture. (2001). Child Nutrition Program Report. http://www.fns.usda.gov/oane/MENU/published/CNP/CNP.HTN.

Fleming, K.H., Heimback, J.T. (1994). Consumption of Calcium in the US: food sources and intake levels. Journal of Nutrition,124:1426S-1430S.

Gordon, A.R., Devaney, B.L. \& Burghardt, J.A. (1995). Dietary effects of the National School lunch Program and the School Breakfast Program. American Journal of Clinical Nutrition,61(suppl):221S-31S. 
Gordon, A.R. \& McKinney, P. (1995). Sources of nutrients in students' diets. American Journal of Clinical Nutrition,61(suppl):232S-40S.

Hill, J.O. \& Prentice, A.M. (1995). Sugar and body weight regulation. American Journal of Clinical Nutrition,62:264-274S.

Ho, C-S. Gould, R.A., Jensen, L.N., Kiser, S.J., Mozar, A., Jensen, J.B. (1991). Evaluation of Nutrient Content of School, Sack and Vending Lunch of Junior High Students. School Food Service Research Review, 15(2):85-90.

Institute of Medicine. (1997). Dietary Reference Intakes for Calcium, Phosphorus, Magnesium, Vitamin D, and Fluoride. Washington, D.C.: National Academy Press.

Institute of Medicine. (1998). Dietary Reference Intakes for Thiamin, Riboflavin, Niacin, Vitamin $B_{6}$, Folate, Vitamin $B_{12}$, Pantothenic Acid, Biotin, and Choline. Washington, DC: National Academy Press.

Institute of Medicine. (2000). Dietary Reference Intakes for Vitamin C, Vitamin E, Selenium, and Carotenoids. Washington, D.C.: National Academy Press.

International Food Information Council. (1998). Nutrient Requirements Get A Makeover: The Evolution of the Recommended Dietary Allowances. Food Insight, September/October 1998:4-5.

Johnston, C.C., Miller, J.Z., Slemenda, C.W., Reister, T.K., Hui, S., Christian, J.C., Peacock, M. (1992). Calcium supplementation and increases in bone mineral density in children. New England Journal of Medicine, 327:82-87.

Kelder, S.H., Perry, C.L., Klepp, K.I., Lytle, L.L., (1994). Longitudinal tracking of adolescent smoking, physical activity, and food choice behaviors. American Journal of Public Health, 84(7):1121-6.

Kennedy, E. \& Goldberg, J. (1995). What Are American Children Eating? Implications for Public Policy. Nutrition Reviews,53(5):11-126.

Marion County Board of Education, Office of Child Nutrition Services. (2000). Ratios of Free/Reduced to Regular Lunch Participation per School.

Martin, J. (1996). The National School Lunch Program-A continuing commitment. Journal of the American Dietetic Association, 96:857-858.

Monsen, E.R. (2000). Dietary Reference Intakes for the antioxidant nutrients: Vitamin C, vitamin E, selenium, and carotenoids. Journal of the American Dietetic Association,100(6):637-640.

Munoz, K.A., Krebs-Smith, S.M., Ballard-Barbash, R., and Cleveland, L.E. (1997). Food Intakes of US Children and Adolescents compared With Recommendations.

Pediatrics, 100(3):323-329. 
National Academy of Science: Food and Nutrition Board. (1989). National research council: Recommended dietary allowances $\left(10^{\text {th }}\right.$ rev. ed.). Washington, D.C.: National Academy of Sciences.

National Center for Health Statistics (1995). Report of final mortality statistics, 1995. Monthly Vital Statistics Report 45(11):Suppl. 2, June 12, 1997.

National Research Council. (1989). Recommended Dietary Allowances (10 ${ }^{\text {th }}$ ed.). Washington, D.C.: National Academy Press.

Nicklas, T.A. (1995). Dietary studies of children and young adults (1973-1988): the Bogalusa Heart Study. American Journal of Medical Science,310(suppl):S101-S1080.

Osganian, K., Nicklas, T., Stone, E., Nichaman, M., Ebzery, M.K., Lytle, L., Nader, P.R. (1995). Perspectives on the School Nutrition Dietary Assessment Study from the Child and Adolescent Trial for Cardiovascular Health. American Journal of Clinical Nutrition, 61(suppl):241S-4S.

Pennington, J.A.T. (1994). Bowes \& Church's Food Values of Portions Commonly Used (16 ${ }^{\text {th }}$ ed.). Philadelphia, PA: J.P. Lippincott Co.

Power, C., Lake, J.K., Cole, T.J. (1997). Measurement and long-term health risks of child and adolescent fatness. International Journal of Obesity,21:507-526.

Public Health Service, US Department of Health and Human Services. (1988). The Surgeon General's report on nutrition and health. Washington, DC: DHHS publication no. (PHS) 88-50210.

Public Health Service, US Department of Health and Human Services. (1991). Healthy People 2000: National Health Promotion and Disease Prevention Objectives. Washington, DC: DHHS publication no. (PHS) 91-50212.

Public Health Service, US Department of Health and Human Services. (1996). Guidelines for School Health Programs to Promote Lifelong Healthy Eating. Atlanta, Georgia: Centers for Disease Control and Prevention, Morbidity and Mortality Weekly Report No. RR-9.

Public Health Service, US Department of Health and Human Services. (1998). $3^{\text {rd }}$ Review of Progress on Healthy People 2000 Objectives for Nutrition. http://odphp.osophs.dhhs.gov/pubs/hp2000/PROGRVW/Nutrition.

Public Health Service, US Department of Health and Human Services. (2000). Healthy People 2010: National Health Promotion and Disease Prevention Objectives. Washington, DC: DHHS publication.

Sizer, F.S. and Whitney, E.N. (2000). Nutrition Concepts and Controversies (Eighth Ed.). Belmont, CA: Wadsworth/Thompson Learning.

StatSoft, Inc. (1995). STATISTICA for Windows [Computer Program Manual].

Tulsa, OK: StatSoft, Inc. 
Trumbo, P., Yates, A.A., Schlicker, S., Poos, M. (2001). Dietary Reference Intakes: Vitamin A, Vitamin K, Arsenic, Boron, Chromium, Copper, Iodine, Iron, Manganese, Molybdenum, Nickel, Silicon, Vanadium, and Zinc. Journal of the American Dietetic Association,101(3): 294-301.

US Department of Agriculture/US Department of Health and Human Services. (1995). The Food Guide Pyramid. Washington, D.C.: US GPO.

US Department of Agriculture. (1999). Results from the 1994-96 Continuing survey of Food Intakes by Individuals. Agricultural Research Service.

US Department of Agriculture. (1995). Final Regulation: School Meals Initiative for Healthy Children. Washington, D.C.: Federal Register, June 13, 1995.

US Department of Agriculture/US Department of Health and Human Services. (1995). Nutrition and Your Health: Dietary Guidelines for Americans $\left(4^{\text {th }}\right.$ Ed.). USDA Home and Garden Bulletin No. 232, 1995.

US Department of Agriculture/U.S. Department of Health and Human Services. (2000). Nutrition and Your Health: Dietary Guidelines for Americans $\left(5^{\text {th }} \mathrm{Ed}\right.$.). USDA Home and Garden Bulletin No. 232, 2000.

US Department of Agriculture, Center for Nutrition Policy and Promotion. (2000). Dietary Guidelines for Americans, 1980-2000. Washington, D.C.

West Virginia Board of Education. (1994). Standards for school nutrition. Title 126, Legislative Rule, WV Board of Education, Chapter 18-2, Series 86, Policy 4321.1.

West Virginia Department of Education. (2001). ASFSA Profile Sheet.

West Virginia Department of Health and Human Resources. (1999). West Virginia 1997 Behavioral Risk Factor Survey: A Report on the lifestyle behaviors affecting the health of West Virginians. Charleston, WV: WVDHHR, Bureau of Public Health. Office of Epidemiology and Health Promotion.

West Virginia Department of Health and Human Resources. (1999). West Virginia Vital Statistics. Charleston, WV: WVDHHR, Bureau of Public Health. Office of Epidemiology and Health Promotion.

Williams, C.L. (1995). Importance of dietary fiber in childhood. Journal of the American Dietetic Association,95(10):1140-1146.

World Health Organization, (1990). Diet, Nutrition and the Prevention of Chronic Diseases. Report of a WHO Study Group. Geneva: WHO Technical Report Series, 797:108.

Wotecki, C.E. (1992). Nutrition in childhood and adolescence: part I. Contemporary Nutrition, 17:1. 
APPENDICES 
APPENDIX A 


\section{Barrackville Elementary \& Middle School}

To Whom It May Concern,

Pam Hamilton has approached Barrackville School about performing an audit of hot and cold lunches eaten by a limited number of second and fourth grade students. Ms. Hamilton has explained that parent permission will be acquired prior to performing the audit.

Based on Ms. Hamilton's assurances that she will obtain all necessary permissions and releases, I will authorize her to perform the audit.

Sincerely,

Gaty/L. Price, Principal 


\section{EAST DALE ELEMENTARY}

\section{NATIONAL SCHOOL OF EXCELLENCE}

Route 3

Fairmont, West Virginia 26554

Phone (304) 367-2132

Janet Crescenzi

Principal

Ms. Pam Hamilton has our consent to study school lunches at

East Dale School. She has permission to study the second and fourth graders with parent permission before she arrives at the school.

Thank-you,

Janet CRescenzi, Principal

Diane Burnside, Assistant Principal 


\section{WATSON Elementary School}

1579 MARY LOU RETTON, DRIVE

FAIRMONT, WEST VIRGINIA 26554

To Whom It May Concern:

I have spoken with Pam Hamilton about her research project. I am willing to allow her to use our school as a participating site. Of course, the children participating in her project will have to have signed permission forms allowing them to participate.

We are glad to be of assistance in this project. The results will be interesting to us as well. We wish Mrs. Hamilton all the best.

Sincerely,

Randall Farley, Principal 
APPENDIX B 


\section{WestVirginiaUniversity}

The Institutional Review Board for the Protection of Human Subjects

DATE: February 24, 2000

NOTICE OF APPROVAL FOR PROTOCOL H.S. \#14737

This research will be monitored for re-approval annually. This protocol was first approved on February 24, 2000.

TO: Pamela Hamilton and

M.Z.A. Nomani

Project Title: Nutrient Content of School Lunches and Packed Lunches as Consumed by Elementary School students

SPONSORING AGENCY: N/A

The Institutional Review Board for the Protection of Human Research Subjects (IRB) has approved the project described above. Approval was based on the descriptive material and procedures you submitted for review. Should any changes in your protocol/consent form be necessary, prior approval must be obtained from the IRB.

According to the Code of Federal Regulations, Section 312.32, investigators are required to notify the FDA and the study sponsor of any adverse experience associated with the use of an investigational drug that is serious and unexpected. A serious adverse experience is considered any event that is fatal or life-threatening, is permanently disabling, requires inpatient hospitalization, or is a congenital anomaly, cancer, or overdose. An unexpected adverse experience is an event that is not identified in nature, severity, or frequency in the current investigator brochure. Any experience reportable to FDA and the sponsor must also be reported immediately to the IRB.

A consent form* $\mathrm{X}$ is__ is not required of each subject.

An assent form $\mathrm{x}$ is__ is not required of each subject.

A recruitment ad has_ has not $\mathrm{X}$ been approved. 
Page 2-

Hamilton

HS \#14737

February 24, 2000

* Only copies of the consent and/or assent form with the IRB's approval stamp may be used with human subject research. is the responsibility of the investigator to submit a revised consent form for the IRB's approval should funding be obtained. This stamped consent form must then be used for subjects enrolled. A copy of each subject's signed Consent/Assent Form must be retained by the investigator and accessible to federal regulatory authorities for at least three years after the study is completed.

Marian 8 . Turner IRB/ACUC Administrator

MJT/baw 


\section{FEB 242000}

Dear Parent:

H.S. \#

You and your student are invited to participate in a nutrition study at your school. The Division of Family \& Consumer sciences at West Virginia University is conducting this study to determine the food habits of elementary school aged children.

Students will be randomly selected to participate in the study. As part of the study, demographic information will be collected regarding age, grade, and gender of the child.

A second aspect of the study will involve weighing your child's food before and after consuming school lunch or the lunch brought from home. This will allow us to determine what the students are actually eating during the school lunch period. All weighing of food items will be conducted using the strictest standards of sanitation.

Participation in the study will not cost anything and should not cause physical or emotional harm to you or your child. Individuals who participate in the study will only be identified by a code number and the information obtained will only be made available to the researcher's involved. The participation of your child in the study will be completely confidential.

Your student is also free to withdraw from the study or refuse to answer any questions at any time without risk of any kind. If you would like more information about the study, please feel free to contact either the Principal Investigator, Pam Hamilton, at (304) 265-4014, Dr. M.z.A. Nomani, at (304) 293-3402 or the West Virginia University Review Board, at (304) 293-7473.

Thank you for your assistance with this important research. Please return the attached consent form to school with your child by $3-29,2000$. If you do not want your child to participate, please indicate on the form.

With regards,

Pam Hamilton

Graduate Student in Human Nutrition \& Foods, West Virginia University 


\section{PARENTAL Or GUARDIAN CONSENT and INFORMATION" FORM}

Nutrient Content of School Lunches and Packed Lunches as Consumed by Elementary school students

\section{Introduction}

I , have been asked to allow my child to participate in this study. Pam Hamilton, who is conducting this research to fulfill the requirements for a master's thesis in Human Nutrition \& Foods at West Virginia University, has explained the study to me in the preceding cover letter.

\section{Purposes of study}

The purpose of this study is to compare the nutritional value of packed lunches and school lunches as consumed by elementary school students.

\section{Description of Procedures}

This study will be performed at three elementary schools within Marion County. The investigator will weigh and record the contents of the student's lunch at the beginning of the lunch period and will then weigh and record what is not eaten at the end of the lunch period. A nutrient analysis program will later be used to determine the nutritional content of actual food consumed. Approximately 20 fourthgrade and 20 second-grade students will be randomly selected from each school. Participation in the study will not exceed one day.

\section{Risks and Discomforts}

Participation in the study is voluntary and will involve no physical or emotional harm to my child. My child is free to withdraw from the study at any time.

\section{Alternative}

My child does not have to participate in the study.

\section{Benefits}

The information obtained in the study will be used for research purposes and may be helpful in evaluating nutrition education needs and healthy food choices for this age group.

\section{Contact Persons}

For more information about this research, I can contact Pam Hamilton at (304) 265-4014 or her supervisor, Dr. M.Z.A. Nomani, at (304) 293-3402.

For information regarding my child's rights as a research subject, I may contact the Executive secretary of the Institutional Review Board at 293-7073.

$\overline{\text { Initials }} \overline{\text { Date }}$




\section{WestVirginiaUniversity}

College of Agriculture, Forestry and Consumer Sciences

Nutrient Content of School Lunches and Packed Lunches as Consumed by Elementary school students

\section{Confidentiality}

I understand that any information obtained as a result of my child's participation in this research will be kept as confidential as legally possible. I understand that these research records, just like hospital records, may be subpoenaed by court order or may be inspected by federal regulatory authorities. My name or that of my child or any information from which we might be identified may not be published without my consent.

\section{Voluntary Participation}

Participation in this study is voluntary. I understand that I may withdraw my child from this study at any time. Refusal to participate or withdrawal will involve no penalty or loss of benefits for me or my child, nor will it affect my child's grade or class standing. I have been given the opportunity to ask questions about the research, and I have received answers concerning areas I did not understand. Upon signing this form, I will receive a copy.

I willingly consent to my child's participation in this research.

Signature of Parent or Guardian

$$
\text { Date }
$$

My child normally eats: (Please mark one of the following) school lunch packed lunch

Sometimes school lunch and sometimes packed lunch 
College of Agriculture, Forestry and Consumer Sciences

\section{ASSENT FORM}

Nutrient content of School Lunches and Packed Lunches as Consumed by Elementary School students

\section{Introduction}

I, have been asked to be in a special study, which has been explained to me by Mrs. Hamilton.

\section{Purposes of study}

I have been told by Mrs. Hamilton that my food will be weighed during lunchtime so that she can see how children my age are eating.

\section{Description of procedures}

This study will be at my school. I will let Mrs. Hamilton or her assistant weigh my food before I eat. I will also let her weigh any leftover food on my tray or in my packed lunch after I have finished eating. I do not have to answer any questions if I don't want to. I will only need to do this for one day.

\section{Discomforts}

Mrs. Hamilton has explained that it may take a little time to weigh my food and that if I need extra time to finish eating, I can have it.

\section{Benefits}

I understand that by letting Mrs. Hamilton weigh my food, I may be helping others to learn about how children my age are eating.

\section{Confidentiality}

I have been promised that anything they learn about me in this study will be kept as secret as possible.

\section{voluntary Participation}

I have been told that I do not have to do this. No one will be mad at me if I refuse to do this or if I decide to quit. I have been allowed to ask questions about the research, and all my questions were answered.

I willingly agree to be in this research.

Signature of subject

Signature of Investigator

Division of Family and Consumer Sciences

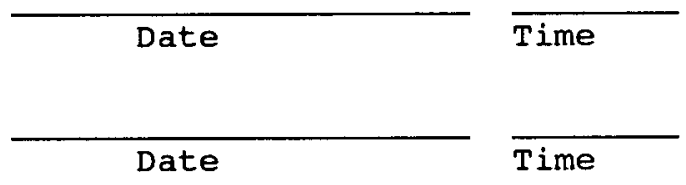




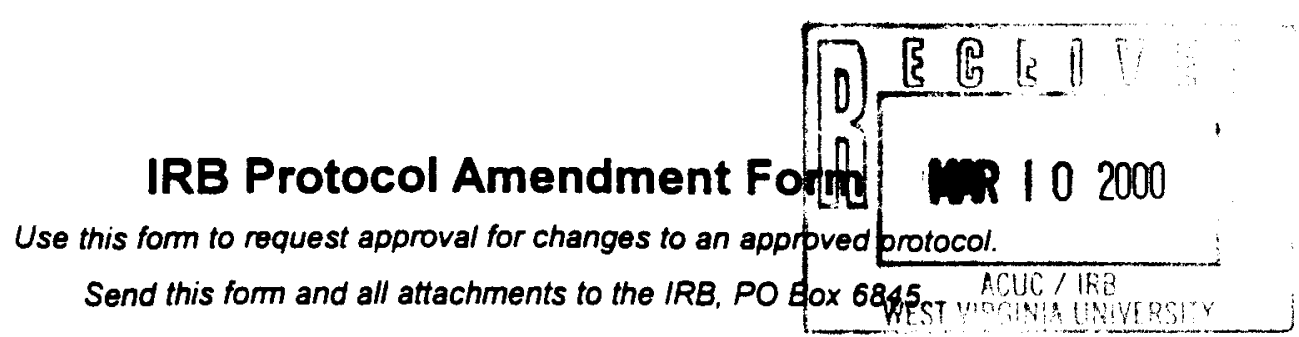

Principal Investigator___ Pamela Hamilton

Date furivgs

HS\# H) And

Protocol Title

Nutrient Content of School Lunches and Packed Lunches as Consumed by Elementary

School Students

Describe changes. Explain in detail your reasons for requesting these changes and which part(s) of the approved protocol will be amended. If adding a new site, attach the appropriate letter(s); if adding new investigators, the principa investigator and all new co-investigators must sign this form. Attach a copy of the revised drug protocol (when appropriate) with revised sections bracketed.

The following change is requested for the initial protocol statement:

Due to a small return of Consent forms for second and fourth grade students,

I want to extend the grades to also include third and fifth graders in the

same three elementary schools that initially consented to participation.

Changes have been made to the consent form and are attached. The cover

letter and Assent form do not require changes due to a more general statement

regarding elementary school students rather than specific grades. Verbal consent

has been granted by the initial participating schools to allow recruitment

of the two additonal grades.

Describe changes to the consent form. Expain which sections of the consent are being changed. Attach a copy of the latest approved consent; a revised and bracketed copy showing changes; and a new, clean copy for approval and stamping.

Changes to the original consent form were only made to the section entitled

"Description of Procedures". Changes only involved description of grades to

be studied as well as the number of schools involved. This final change has been

made in the event that it is necessary to include additional site participation.
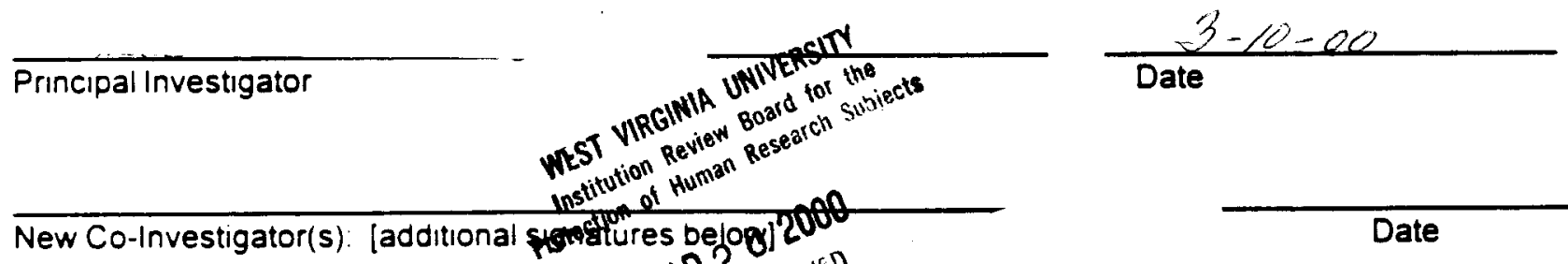

New Co-Investigator(s): [additional soreldures belog) 200

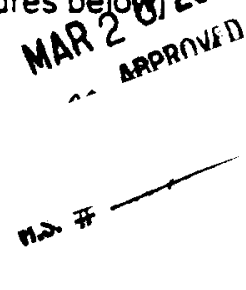

Date 
College of Agriculture, Forestry and Consumer Sciences

H.S. \# 14737

PARENTAL Or GUARDIAN CONSENT and INFORMATION FORM

Nutrient Content of School Lunches and Packed Lunches as Consumed by Elementary School Students

\section{Introduction}

I , have been asked to allow my child

to participate in this study. Pam Hamilton, who is conducting this research to fulfill the requirements for a master's thesis in Human Nutrition \& Foods at West Virginia University, has explained the study to me in the preceding cover letter.

Purposes of Study

The purpose of this study is to compare the nutritional value of packed lunches and school lunches as consumed by elementary school students.

\section{Description of Procedures}

This study will be performed at elementary schools within Marion County. The investigator will weigh and record the contents of the student's lunch at the beginning of the lunch period and will then weigh and record what is not eaten at the end of the lunch period. A nutrient analysis program will later be used to determine the nutritional content of actual food consumed. Approximately 40 students will be randomly selected from each school. Participation in the study will not exceed one day.

\section{Risks and Discomforts}

Participation in the study is voluntary and will involve no physical or emotional harm to my child. My child is free to withdraw from the study at any time.

\section{Alternative}

My child does not have to participate in the study.

\section{Benefits}

The information obtained in the study will be used for research purposes and may be helpful in evaluating nutrition education needs and healthy food choices for this age group.

\section{Contact Persons}

For more information about this research, I can contact Pam Hamilton at (304) 265-4014 or her supervisor, Dr. M.z.A. Nomani, at (304) 293-3402.

For information regarding my child's rights as a research subject, I may contact the Executive Secretary of the Institutional Review Board at 293-7073.

\section{Initials Date}

Division of Family and Consumer Sciences 


\section{West VirginiaUniversity}

College of Agriculture, Forestry and Consumer Sciences

Nutrient content of School Luncheg and Packed Lunches as Consumed by Elementary school students

\section{Confidentiality}

I understand that any information obtained as a result of my child's participation in this research will be kept as confidential as legally possible. I understand that these research records, just like hospital records, may be subpoenaed by court order or may be inspected by federal regulatory authorities. My name or that of my child or any information from which we might be identified may not be published without my consent.

\section{Voluntary Participation}

Participation in this study is voluntary. I understand that I may withdraw my child from this study at any time. Refusal to participate or withdrawal will involve no penalty or loss of benefits for me or my child, nor will it affect my child's grade or class standing. I have been given the opportunity to ask questions about the research, and I have received answers concerning areas I did not understand. Upon gigning this form, I will receive a copy.

I willingly consent to my child's participation in this research.

signature of Parent or Guardian

Signature of Invegtigator
Date

Date
Time

Time

My child normally eats: (Please mark one of the following)

school lunch packed lunch

Sometimes school lunch and sometimes packed lunch

Page 2 of 2

Division of Family and Consumer Sciences 
APPENDIX C 
Pam Hamilton

Rt4, Box 136 A

Grafton, West Virginia 26354

Dear Pam,

This letter is to inform you that you have permission to use the research study by Ching-Shiang Ho entitled "Evaluation of nutrient content in school and alternative lunches as selected and consumed by intermediate students". I served as Ching-Shiang's supervisory committee chair at the University of Utah and fully understand the amount of work that went into this research.

Please give Ching-Shiang Ho credit when using any part of her study in your own research. This letter also confirms that you are adapting this study to meet your research needs.

I hope this clarifies the information you needed. Please contact me if you need further clarification 785-532-2207 or gould@humec.ksu.edu.

Sincerely,

Kebecca Gould, $\mathrm{PhD}$, RD

Associate Professor 
Data Collection Sheet

Student Age:

\begin{tabular}{|c|c|c|c|}
\hline School Lunch & Initial Amounts & Wasted Amounts & Difference \\
\hline \multicolumn{4}{|l|}{ Vegetable } \\
\hline \multicolumn{4}{|l|}{ Vegetable } \\
\hline \multicolumn{4}{|l|}{ Fruit } \\
\hline \multicolumn{4}{|l|}{ Bread } \\
\hline \multicolumn{4}{|l|}{ Meat } \\
\hline \multicolumn{4}{|l|}{ Sandwich } \\
\hline \multicolumn{4}{|l|}{ Soup } \\
\hline \multicolumn{4}{|l|}{ Entree } \\
\hline \multicolumn{4}{|l|}{ Dessert } \\
\hline \multicolumn{4}{|l|}{ Milk } \\
\hline \multicolumn{4}{|l|}{ Beverage } \\
\hline \multicolumn{4}{|l|}{ Other } \\
\hline \multicolumn{4}{|l|}{ Other } \\
\hline $\begin{array}{r}\text { Packed Lunch } \\
\end{array}$ & Initial Amounts & Wasted Amounts & Difference \\
\hline \multicolumn{4}{|l|}{ Vegetable } \\
\hline \multicolumn{4}{|l|}{ Vegetable } \\
\hline \multicolumn{4}{|l|}{ Fruit } \\
\hline \multicolumn{4}{|l|}{ Bread } \\
\hline \multicolumn{4}{|l|}{ Meat } \\
\hline \multicolumn{4}{|l|}{ Sandwich } \\
\hline \multicolumn{4}{|l|}{ Soup } \\
\hline \multicolumn{4}{|l|}{ Entree } \\
\hline \multicolumn{4}{|l|}{ Dessert } \\
\hline \multicolumn{4}{|l|}{ Beverage } \\
\hline \multicolumn{4}{|l|}{ Other } \\
\hline Other & & & \\
\hline & & & \\
\hline
\end{tabular}


APPENDIX D 


\section{DETERMINATION OF INDIVIDUAL WEIGHTS OF FOOD ITEMS MAKING UP A COMBINATION DISH/SANDWICH IN PACKED LUNCHES}

Example: Ham and Cheese Sandwich on White Bread with Mayonnaise

Total Weight of Sandwich $($ Taken with Acculab Digital Scale $)=\mathbf{1 1 7 . 3 ~ g}$.

Individual Weights of Portions of Food Making up Sandwich:

First Data Bank, Inc. (1998). Nutritionist V. Version 2.1.1. CA, San Bruno: Hearst Corp.

Pennington, J.A.T. (1994). Bowes \& Church's Food Values of Portions Commonly Used (16 ${ }^{\text {th }}$ ed.). Philadelphia, PA: Lippincott.

Values as determined from a single serving size using the above references for food portion weights:
2 slices white bread
$84 \mathrm{~g}$.
1 slice Ham
28.5 g.
1 slice American Cheese
$28 \mathrm{~g}$.
$1 \mathrm{~T}$. mayonnaise
$15 \mathrm{~g}$.
$155.5 \mathrm{~g}$.

$\underline{\text { Actual Sandwich Weight as Determined for Student Lunch }}=\underline{117.3 \mathrm{~g} .}=.76$ Sandwich Weight as Determined from Above Calculation $=155.5 \mathrm{~g}$.

2 slices white bread

1 slice ham lunchmeat

1 slice American cheese

1 Tablespoon mayonnaise

$$
\begin{aligned}
& 84 \text { g. } \quad \text { x } .76=63.8 \text { g.* } \\
& 28.5 \text { g. } x .76=21.6 \text { g. } * \\
& 28 \text { g. } \quad \text { x } .76=21.2 \text { g.* } \\
& 15 \mathrm{~g} . \quad \mathrm{x} .76=\frac{\mathbf{1 1 . 4 \mathrm { g } .} *}{\mathbf{1 1 8 . 0 \mathrm { g } .}}
\end{aligned}
$$

*Values in bold were entered into nutrient analysis as individual food components making up the combination dish/sandwich. Amount of sandwich consumed was calculated using the same method. If the student left all bread and no meat or cheese, the approximate amount of each food item was noted at the time of weighing and estimated as closely as possible. 
APPENDIX E 


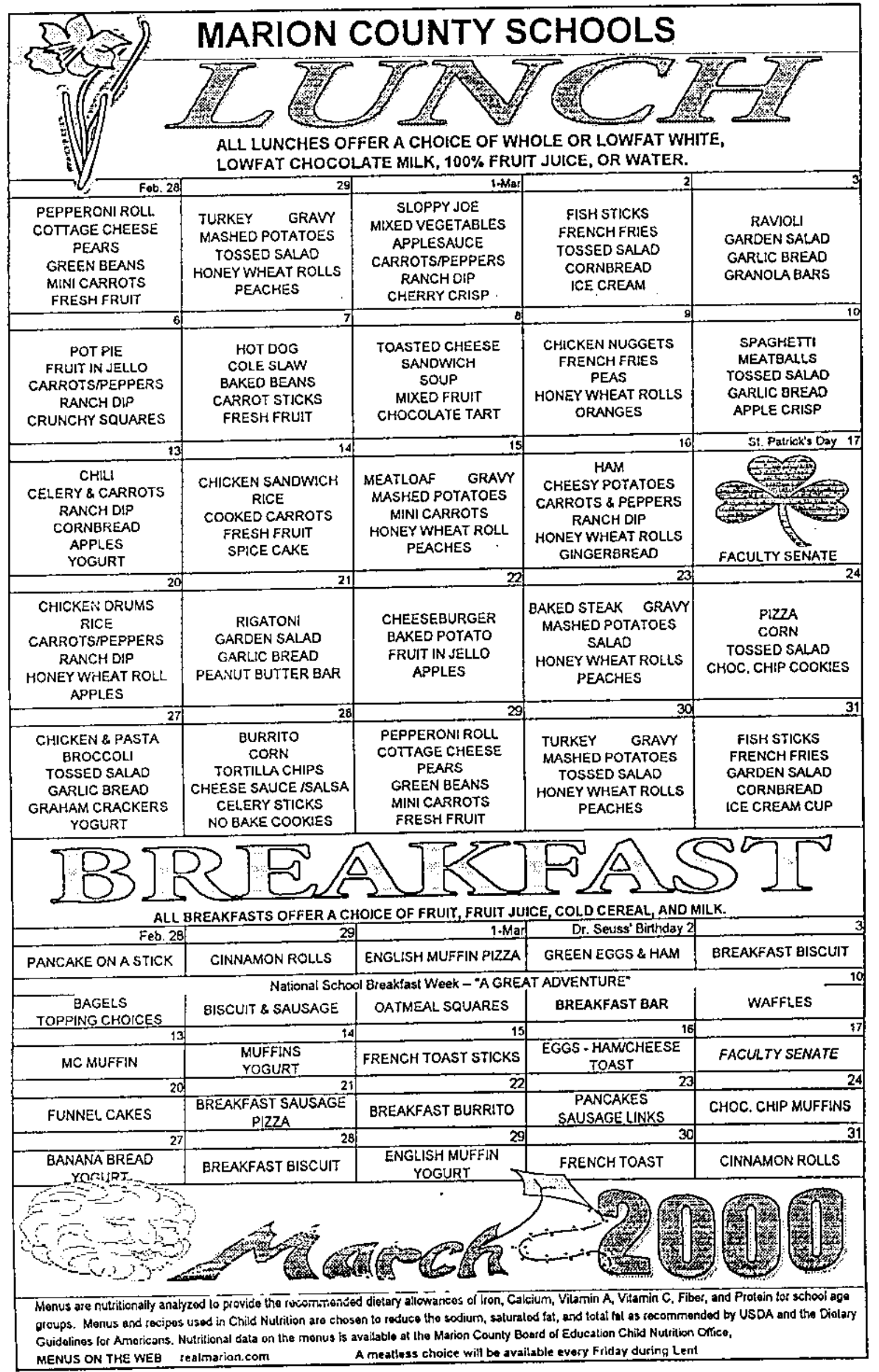




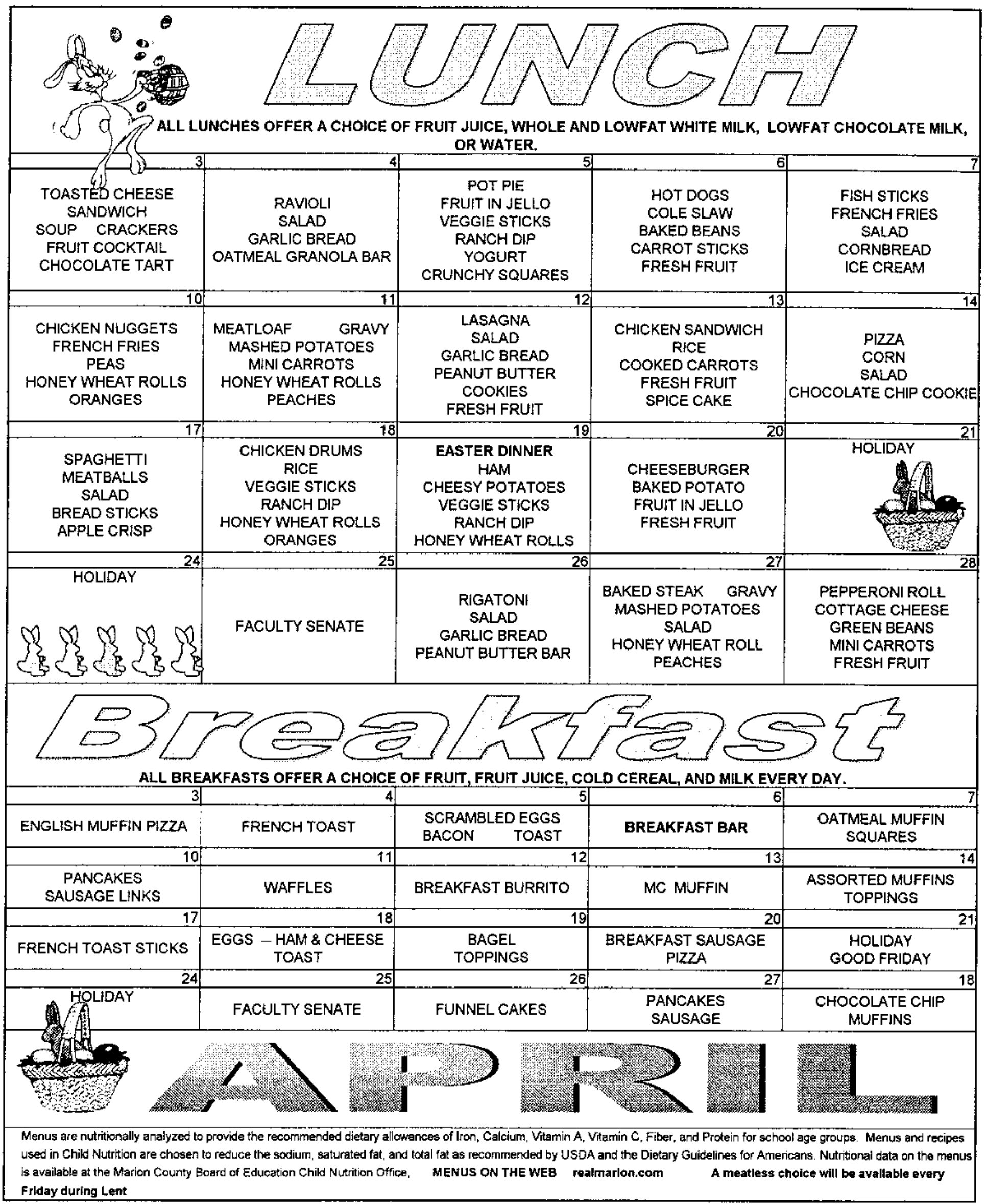


Page 1

$03 / 1912000$ thro $03 / 13 / 2000$

\section{Recioe Name} Portion Pplan : $\mathrm{Kg}$ Size loty icals chol Sodm Fiber Iron
HARIOH COUNTY SCHOOLS

Lunch, $k-4$
$03-14-2000$

HONOAY - 03/13/2000

CHILI COH CARNE \& BEANS - HC CARCKERS

CARROT STICKS

CELERY STICKS

RANCH DRESSING CUPS

CORNBREAD - from GiX

WARGARINE

FRUIT, FRESH ASSORTEO

YOGURT, FHESH, ASSORTEO

JUICE CHOICE

JILK CHOICE - LUNCH

JAILY AYERAGE

$\checkmark$ OF CALORIES

$1 / 2$ CUP
4 EACH
$1 / 8$ CUP
$: 1 / 8$ CUP
serving
SERYINGS
PAT
$11 / 2$ EACH
1402.
1402.
11 CUP

1: 174

152

112

1100

$1 ! 57$

$0.000 .00 \quad 0.00$

$\begin{array}{llllll}1 & 86 & 8 & 230 & 0.00 & 1.27\end{array}$

$1: 39 \quad 0 \quad 39 \quad 0.00 \quad 0.00$

$\begin{array}{llllll}1 & 35 & 0 & 0 & 1.33 & 0.12\end{array}$

$1 ; 114$

1) 71

1) 169

1,804

820,01

$5 \quad 0.06 \quad 0.24$

$\begin{array}{lllll}145 & 1.03 & 0.51 \quad 286.04\end{array}$

$72 \quad 1114 \quad 5.10 \quad 4.79 \quad 615.95$
Hg , RE

Calc Vit-A Yit-c
Mg $G \quad G \quad G \quad G$

t-C Prot Carb T-Fat S-Fat

$*$ - Denotes Hissing hutrient Values

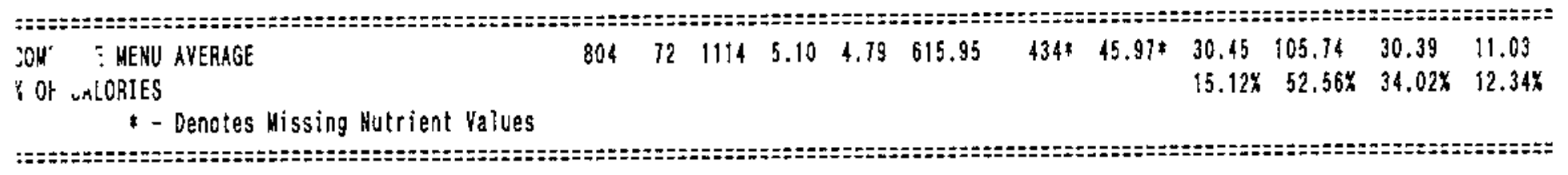


MARION COUWTY SCHOOLS

O20 - WATSON ELEMENTARY
QRIY PRODUCTION RECORD

MONDKY - 03/13/2000
$B: L \quad, K-4 \ldots \ldots \ldots \ldots \ldots \ldots$ Students $(900)$

Signature

Recipe \& ingredients

R01087 CHILI CON CARNE \& BEANS -HC (USOh 0-20-)
Adults $(0)$

TotaT[100]
---- PLANNED --- $\quad$-- ACTUAL --

HuHenu 'Reimb- Ala : Reimb- Ala 'Leftover:

portion Size Group , ursble Carte TOTAL, ursable Carte, Short(-), Temp

\begin{tabular}{|c|c|}
\hline 000712 BEEF GROEND,75/25 Raw-to cook \& & 10 LBS (raw weight \\
\hline 011284 ONIOHS, DEHYDRATED FLAKES......... & $402 s$ \\
\hline 002020 GARLIC POKDER.................. & 3 TBSP \\
\hline 011333 PEPPERS, SWI GREEN, RAH............ & $23 / 4$ CUPS +4 TBSP \\
\hline 002030 PEPPER, BLACK................... & 1 TBSP + 1 TSP \\
\hline 002009 CHILI POWDER................... & $1 / 3 \mathrm{CUP}+2 \mathrm{TSP}$ \\
\hline 002028 PAPRIKA $\ldots \ldots \ldots \ldots \ldots \ldots \ldots \ldots$ & 2 TBSP \\
\hline O02026 ONION POWDER.................. & 2 TESP \\
\hline 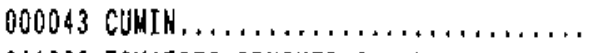 & $1 / 4 C U P+3 / 8 T S P$ \\
\hline 011965 TOMATOES, CRUSHED, CANNED, HERTED... & 1 " $10 \mathrm{CAN}$ \\
\hline 014429 WATER.............................. & 1 GAL +2 CUPS \\
\hline 011887 TOMATO PASTE, CANMEO, M/SALT....... & $1 / 2: 10 \mathrm{CAN}$ \\
\hline 016029 BEANS, KIDNEY, ALL TYPES, CANNED, DRA & $1 \# 10 \mathrm{CAN}$ \\
\hline 001009 CHEESE, CHEODAR, AMERICAN. . . . . . . . & 3 LBS \\
\hline
\end{tabular}

$1 / 2$ CUP iEntree

$100 \quad 0 \quad 100 !$

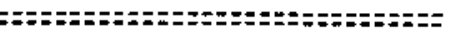

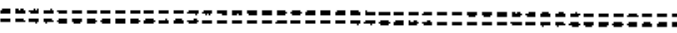
RO0232 CRACXERS

4 EACH 'Side(p2)

01. CRACKERS, SALTIMES(INCL OYSTER, SOD

$400 \operatorname{cracker}(s)$

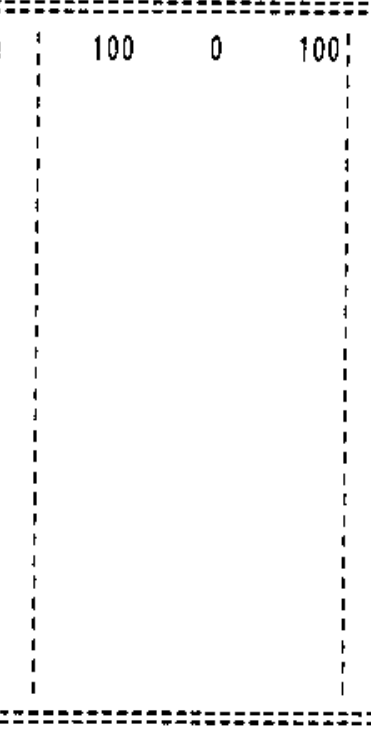

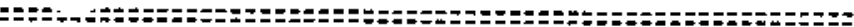

HOOO22 CARROT STICKS

1/8 cup 'Side(p2)! $100 \quad 0 \quad 100$ :

011124 CARROTS, FRESH, RAW

$5\lfloor$ LBS

$100 \quad 0 \quad 1001$

$100 !$

$=2=$

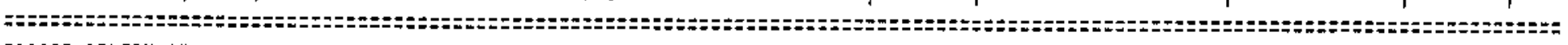

F00267 CELERY STICKS

$1 / 8$ CUP :Side(p2): $100 \quad 0 \quad 100:$

011143 CELERY, FRESH, RAll

$41 / 4$ LBS

:z:z:z:z:z:z:z:z:z:z:z:z:z:z:z:z:z:z:=
RO1081 RANCH DRESSING CUPS (Purchased)

090317 RANCH, PC PAC, 102/1 OL 99 BID ... $100 \mathrm{FL} \mathrm{OZ}$

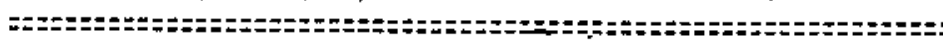

RO1094 CORMBREKD - from mix (Hix)

SERVINGS iside(D2)! $100 \quad 0 \quad 100$ :

085275 CORNGREAD MIX

5 LBS

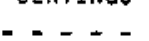

serving 'side(p2)! $100 \quad 0 \quad 100$ ?

1001

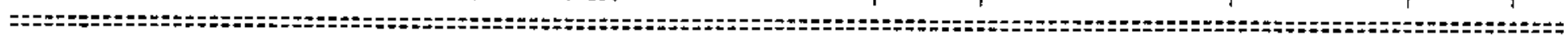

RO0287 WARGARIAE

PAT Side(p2): $100 \quad 0 \quad 100 ;$

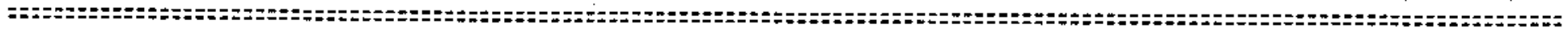

R00245 FRUIT, FRESH ASSORTED

$1 / 2$ EACH 'Side (p2)! $100 \quad 0 \quad 100 !$

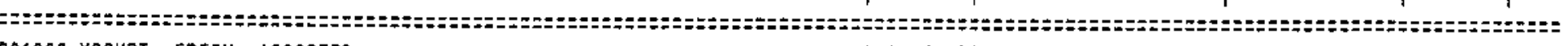

HO1022 YOGURT, FRESH, ASSORTED

402. Side(p2): $100 \quad 0$ 100:

08. YOGURT, LOWFAT, DANNON DANIMALS. 100 Serving

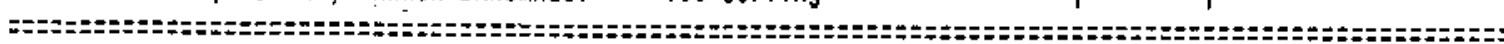

R00325 JUICE CHOICE

40z. 'Side(p2)i $100 \quad 0 \quad 100$ ! 
Page 1

$03 / 1519000$ thru $03 / 15 / 2000$

Portion , Plan: Hg Hg $G$ Hg Hg he Hg $G$ G Size oty icals chol sodn fiber Iron Calc Vit-A Vit-C prot carb T-Fat s-fat

Recipe Nane l

MEOHESDAY - 03/15/2000

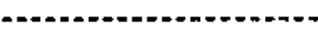

\section{MEATLOAF}

MASHED POTATOES

GRAVY, BROWN: scratch

CARROTS, MINI MHOLE

HONEY WHEAT ROLLS

MARGARINE

PEACHES: canned, light syrup

JUICE CHOICE

WILK CHOICE - LUNCH

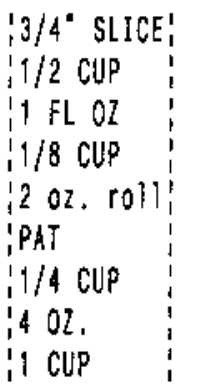

$1: 189 \quad 63$

$1: 91$

$\begin{array}{llllllll}1 & 21 & 3 & 154 & 0.06 & 0.11 & 1.04\end{array}$

$\begin{array}{lllllll}1 & 9 & 0 & 7 & 0.66 & 0.11 & 5.94\end{array}$

$\begin{array}{lllllll}1 & 128 & 0 & 219 & 1.59 & 1.34 & 1.15\end{array}$

$\begin{array}{lllllll}1 & 39 & 0 & 39 & 0.00 & 0.00 & 0.00\end{array}$

$\begin{array}{lllllll}1 & 34 & 0 & 3 & 0.83 & 0.23 & 1.91\end{array}$

$\begin{array}{lllllll}11 & 11 & 0 & 5 & 0.06 & 0.24 & 9.17\end{array}$

$\begin{array}{lllllll}1 & 169 & 17 & 145 & 1.03 & 0.51 & 286.04\end{array}$

$1: 75492$

$\begin{array}{llll}761 & 7.25 & 5.07 & 370.87\end{array}$

OAILY AVERAGE

* OF CALORIES

* - Denotes Hissing Nutrient Values

\begin{tabular}{rrrrrr}
30 & 4.44 & 15.21 & 8.48 & 10.30 & 3.87 \\
22 & 20.58 & 2.29 & 16.01 & 2.29 & 0.97 \\
13 & 0.01 & 0.35 & 1.85 & 1.48 & 0.89 \\
618 & 2.04 & 0.22 & 2.23 & 0.04 & 0.00 \\
$12^{*}$ & 1.13 & 4.16 & 25.03 & 1.20 & 0.20 \\
0 & 0.00 & 0.00 & 0.00 & 4.35 & 0.85 \\
22 & 1.53 & 0.29 & 9.30 & 0.02 & 0.00 \\
5 & 16.02 & 0.45 & 17.65 & 0.13 & 0.03 \\
139 & 2.30 & 8.04 & 23.56 & 5.02 & 3.11 \\
\hline $866 *$ & 48.07 & 31.01 & 104.11 & 24.83 & 9.95 \\
& & $16.44 \%$ & $55.20 \%$ & $29.61 \%$ & $11.88 \%$
\end{tabular}

$\begin{array}{llllllllllll}754 & 92 & 76 & 1.25 & 5.07 & 370.87 & 866 * & 48.07 & 31.01 & 104.11 & 24.83 & 9.95\end{array}$ 
MARTOH COUNTY SCHOOLS

020 - MKTSOH ELEKENTRRY
AKTT PRODUCTIOH RECORO

WEDNESDAY - 03/15/2000
$B: L \quad, k-4 \ldots \ldots \ldots \ldots \ldots \ldots$ Students $(100)$

Signature

Recipe \& Ingredients Recipe ingredints ROO165 MEATLOAF (USOA D-27)

\begin{tabular}{|c|c|}
\hline 011887 TOMATO PASTE, CANKEO, $/$ /SALT....... & $1 \mathrm{LB}+1202 \mathrm{~S}$ \\
\hline 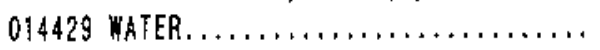 & 2 CUPS \\
\hline 000082 BEEF STOCK.................... & $10 T$ \\
\hline 001091 HILK,ORY, HON FAT POWDER, W/O VITAM & $41 / 2025$ \\
\hline 013311 BEEF GROUND, REGLLAR, EAXEO, WELL D & 17 LBS (raw weight) \\
\hline 020038 OATMERL $\ldots \ldots \ldots \ldots \ldots \ldots \ldots \ldots \ldots$ & $11 B+12025$ \\
\hline 001123 EGGS, WHOLE, FRESH \& FROZEN........ & 8 large \\
\hline 011284 OHIONS, DEHYORATED FLAKES.......... & $2 t / 402 s$ \\
\hline 011143 CELERY, FRESH, RAY. ............. & $1 \mathrm{LB}$ \\
\hline 002029 PARSLEY,DRIED ................ & $1 / 2 \mathrm{CHP}$ \\
\hline 002030 PEPPER, BLACK $\ldots \ldots \ldots \ldots \ldots \ldots$ & 1 TBSP \\
\hline 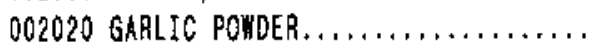 & $2 T B S P$ \\
\hline 002003 BASIL, GROUND ................... & $1 / 2 \mathrm{TBSP}$ \\
\hline 002027 OREGAMO, GROUND.................. & $1 / 2$ TBSP \\
\hline 002023 MARJORAM, DRIED $\ldots \ldots \ldots \ldots \ldots \ldots$ & 1 TSP \\
\hline 002042 THYME, GROUND $\ldots \ldots \ldots \ldots \ldots \ldots \ldots \ldots$ & $1 / 4 \mathrm{TSP}$ \\
\hline
\end{tabular}

Adults $(0)$ Total(ivo)
-..-- PLAHMED -..- -- ACTUAL --

Numenu 'Reimb- Ala i Reimb- Ala iLeftover:

Portion size Group iursble Carte TOTAL' ursable Carte'Short(-) Temp

ROO IASHED POTATOES (KC I-2)

$1 / 2$ cup 'side(p2)i $100 \quad 0 \quad 100$

093463 potato Granules.

$3 / 4 * 10$ CAN

3/4" SLICE Entree: 100 0 100!

$100 !$

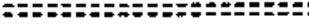

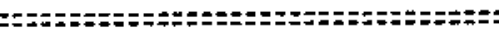

R00120 GRAYY, BROWH: scratch (USOR G-3)

$1 \mathrm{FL} \mathrm{OL} \mathrm{iside(p2):} 100 \quad 0 \quad 100:$

001001 BUTTER, W/SALT.

6 $1 / 4025$

020081 FLOUR, ALL PURPOSE WHITE, ENAICHED, $77 / 8$ OLS

000082 BEEF STOCK.

3 QTS $+11 / 4$ CUP

$1 \mathrm{TBSP}+1 / 8 \mathrm{TSP}$

002026 ONION POWDER.

$3 / 8$ TSP

O02030 PEPPER, BLACK.

נ/8

$\ldots .$.

R01044 CARROTS, MINI WHOLE

011124 CARROTS, FRESH, RAN.

4 L.BS + $135 / 802 S$

$1 / 8$ cup iside (p2)

B00305 HONEY WHEhT ROLLS (MC B-3)

20z. roll : side(p2)

020083 FLOUR, BREAD, ENRICHED

4 OTS $+11 / 8$ CUP

020080 FLOUR, WHOLE WHEAT

$10 T+13 / 4$ CUP

019335 SUGAR, GRANULATED............... 5 3/4 IBSP

093364 Yeast, SAF Instant - GhGE FOODS.. 2 27/8 07S

002047 SALT, TABLE.

2 TESP $+25 / 8$ TSP

019296 HOHEY, STR/EXTRACTED.

12 TBSP

004128 MARGARINE, IMITH, UNSPEC OIL...... $53 / 4.025$

OPSing MATER.

2 OTS + $5 / 8$ CHP

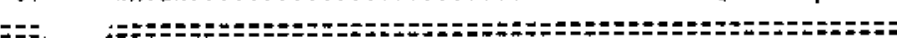

RO0287 MARGARINE

PAT 'Side(p2):

100

$100 \quad 0 \quad 100 !$

$00 !$

sz:zz:zz:zz:

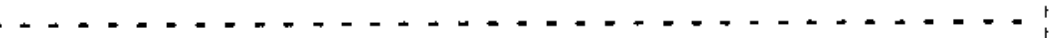

$100 \quad 0 \quad 100 !$

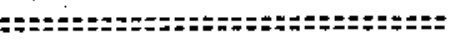


MARION COUNTY SCHOOLS

O20 - WATSON ELEMENTARY
DAILY PRODUCTIOH RECORD

NEDNESDRY - 03/15/2000

$B: L$ Unah, K-4 Students $(100)$ Adults $(0)$ Total $(100)$

Signature

--.-- PLANEDO -... Nukenu 'Reimb- Ala 'Reimb- Ala 'Leftover!

Recipe \& Ingredients Portion Size Group iursble Carte TOTAL ursable Carte', Short(-) Temp

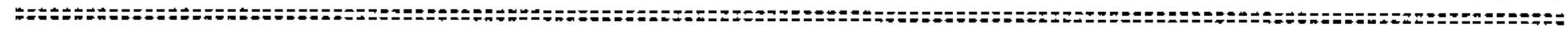
R00437 PEACHES: canned, light syrup

009240 PEACHES, CANNED, LIGHT SYRUP $1 / 4$ Cup :Side(p2) $21 / 8 \# 10$ CAHS

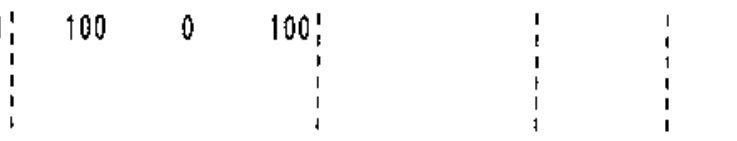

$\therefore \quad$ 40l, iside(p2)!

RO0325 JUICE CHOICE

- 2 -

- . . . . . . . . . .

z:z:zz:z:z:z:z:z:zz:z:z:z=:

1 cup inilk

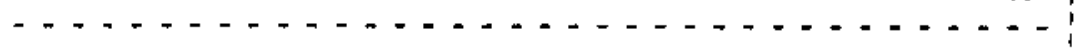

$100 \quad 0 \quad 1001$

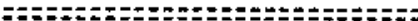




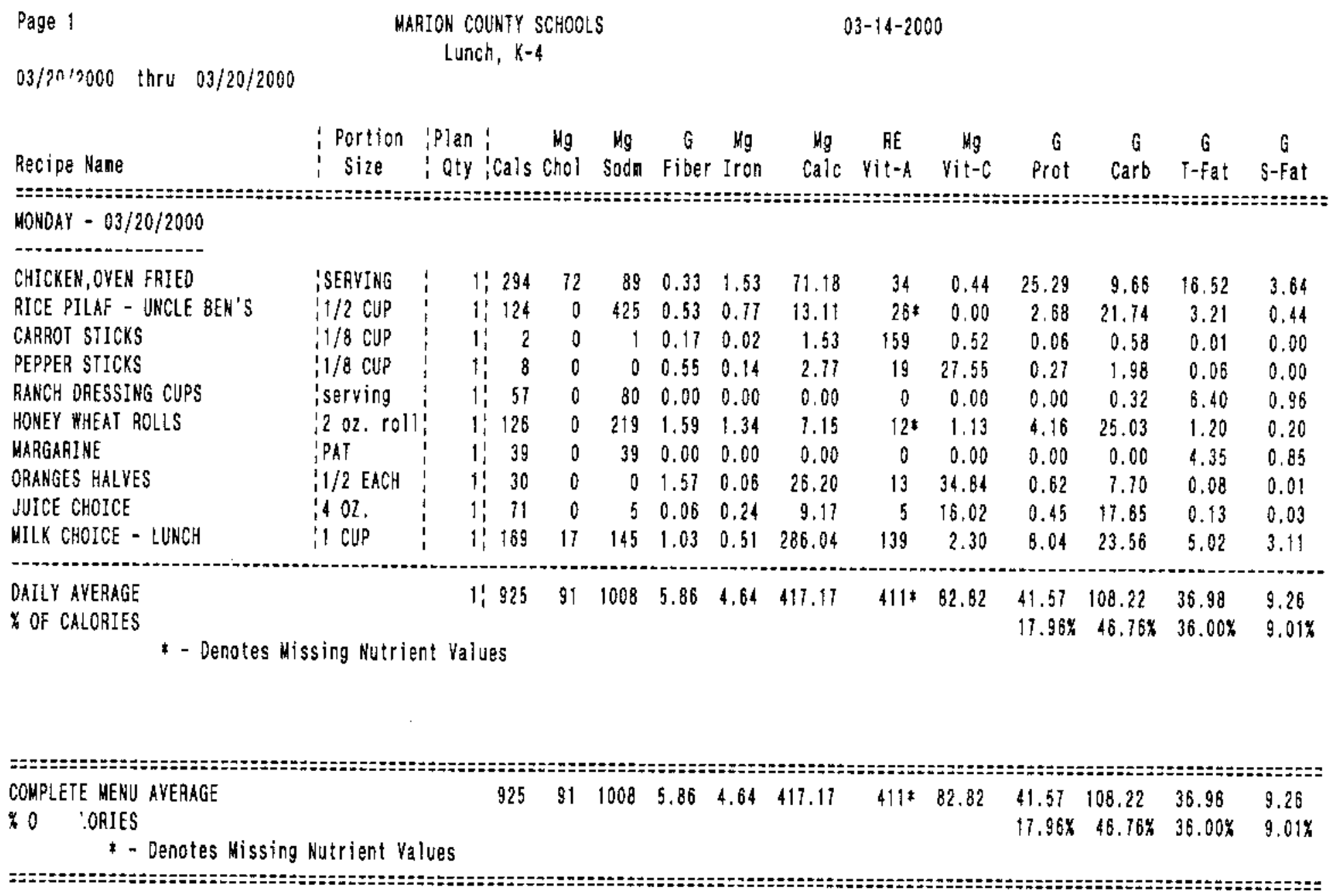


MARTON COUNTY SCHOOLS

020 - WATSON ELEMENTARY
DAILY PRODUCXON RECORD

HONDKP - 03/20/2000

$B: L \quad, K-4 \ldots \ldots \ldots \ldots \ldots \ldots$ students $(100)$

$k d u) t s(0)$

Total $(100)$

Signature

Recipe \& Ingredients

portion size Group :ursble Carte toraL' ursable Carte', Short(-), Temp

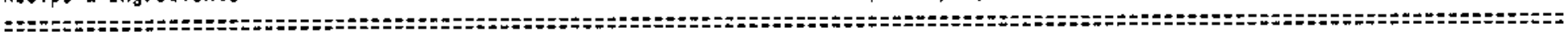
R08003 CHICKEH, OYEN FRIED (USDA D-29) SERVING 'Entree

005060 CHICKEN BREAST, ROASTED with SKIN 005094 CHICKEN THIGH, ROASTED with SKIH. O05069 CHICKEH DRUMSTICK, ROASTED with S 005103 CHICKEN HING, ROASTED With SKIN. 020081 FLOUR, ALL PURPOSE WHITE, ENRICHED, O01091 MILX, DRY, NOH FKT POWDER, H/O YITAK 002034 POULTRY SEASOHING.............

002030 PEPPER, BLACK...................

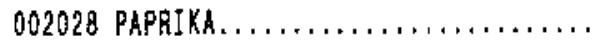

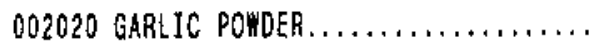

004623 OIL, VEG, TYPE A-COMMOD.

$34 \mathrm{1} / 2$ breast, e/p

34 thigh, e/p

32 druastck $(s), e / p$

32 wing(s), e/p

2 LBS

1 L8

3 TESP

2 TESP

1 TBSP

3 TBSP

3 CUPS $\begin{array}{lll}100 & 0 & 100\end{array}$

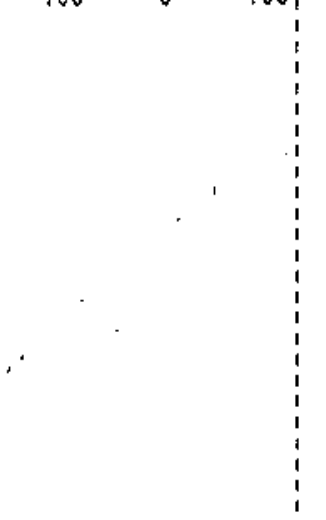

RO1023 RICE PILAF - UNCLE BEN'\$

$1 / 2$ Cup iside $(p 2)$

000032 RICE PILAF

3 BOXES

014429 WTER. 2 GALS + 1/8 QT

004071 MARGAAIME, REG, CORN(HYDR) $113 / 4025$

$\ldots \ldots$

$100 \quad 0 \quad 100 !$

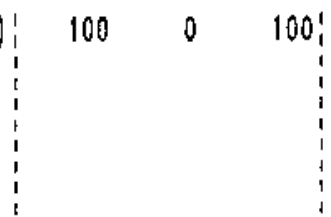

$=$

ROOOLS CARROT STICKS

$1 / 8$ CuP iside $(02): \quad 100 \quad 0 \quad 100:$

011124 CARROTS, FRESH, HAWW

5 LBS

$\cdots$

R00306 PEPPER STICKS

011333 PEPPERS, SWT, GREEH, RKWW.

3 LBS $+6 \quad 1 / 2$ OLS

1/8 cup iside(p2)! $100 \quad 0 \quad 100 !$

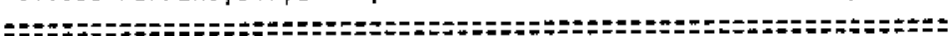

RO1081 RANCH DRESSING CUPS (PUIChaseo,

rerving 'side(p2)

090317 RANCH, PC PAC, 102/1 OL 99 BID....

$100 \mathrm{FL} 02$

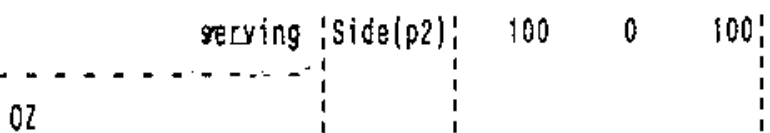

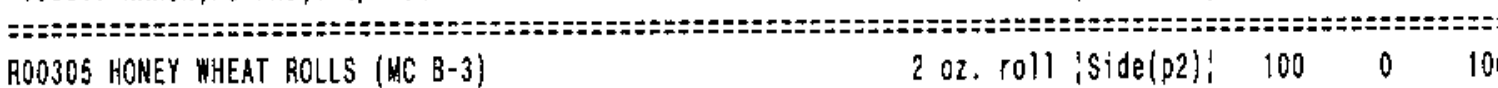

202. 1011

020083 FLOUR, BREAD, ENRICHED.

4 OTS $+11 / 8$ CUP

020080 FLOUR, WHOLE WHEAT

$10 T+13 / 4$ CUP

019335 SUGAR, GRANULATED.............. 5 3/4 TBSP

093364 Yeast, SAF Instant - GAGE FOODS., $27 / 8$ OZS

002047 SALT, TABLE ....................

$2 \mathrm{TBSP}+25 / 8 T S P$

019296 HONEY, STR/EXTRACTED ........... $111 / 2$ IBSP

004128 MARGARINE, IHITH, UNSPEC OIL...... $53 / 4$ OZS

014429 MATER,

2 QTS $+5 / 8$ CUP

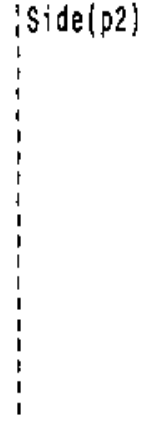

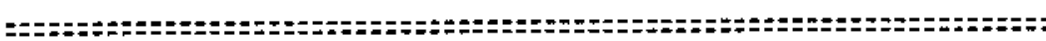

RO0287 MARGARINE

PAT \{side(p2)

$=$

ROOOB5 ORANGES HALVES

$1 / 2$ EACH 'side(p2)

50 each, $2-5 / 8^{\circ} \mathrm{dia}$

009200 ORANGES, FRESH.

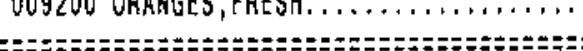

zz:z:z:z:z:z:z:= 
MARION COUNTY SCHOOLS

020 - HATSON ELEMENTARY
DAILY PRODUCTION RECORO

HONOAY - 03/20/2000

$8:\left(\right.$ Unah $^{\mathrm{n}}, \mathrm{K}-4 \ldots \ldots \ldots \ldots \ldots \ldots$ Students $(100)$

Adults $(0)$

Total $(100)$

signature

---- PLANNED -..- -- ACTUAL --

Recipe \& Ingredients

'Nukenu 'Reinb- Ala i Reimb- Ala 'Leftover'

Portion size Group iursble carte TOTaL, ursable Carte',Short(-), 'Temp

ROO325 JUICE CHOICE

40z. 'Side(p2)!

. . . . . . . . . . . . . . . . . . . . . !

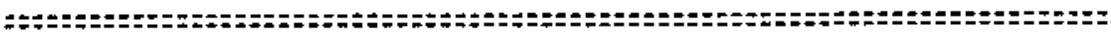

800301 MILK CHOICE - LUNCH

1 CUP iHilk

... . . . . . . . . . . . . . . . . . . . . !

$100 \quad 0 \quad 100 !$

001

$100 \quad 0$

$100 ;$ 
Page 1

$04 / 05 / 2000$ thru $04 / 05 / 2000$

Lunch, $k-4$

\begin{tabular}{|c|c|c|c|c|c|c|c|c|c|c|c|c|c|}
\hline Recipe Hane & $\begin{array}{l}\text { Portion } \\
\text { Size }\end{array}$ & $\begin{array}{l}\text { Plan } \\
\text { Oty icals }\end{array}$ & $\begin{array}{l}\text { Nig } \\
\text { chol }\end{array}$ & $\underset{\text { Sodm }}{\text { Nig }}$ & $\begin{array}{c}6 \\
\text { Fiber }\end{array}$ & $\begin{array}{l}\mathrm{Hg} \\
\text { Iron }\end{array}$ & $\begin{array}{l}\mathrm{Hg} \\
\text { calc }\end{array}$ & $\begin{array}{c}\text { RE } \\
V i t-A\end{array}$ & $\begin{array}{c}\mathrm{Hg} \\
\mathrm{Vit}-\mathrm{C}\end{array}$ & $\begin{array}{c}G \\
\text { Prot }\end{array}$ & $\begin{array}{c}G \\
C a r b\end{array}$ & $\begin{array}{c}G \\
T-F a t \\
0=2=0\end{array}$ & $\begin{array}{c}G \\
S-F a t\end{array}$ \\
\hline \multicolumn{14}{|l|}{ DNESOAY $=04 / 05 / 2000$} \\
\hline & 1314 ClP & 1: 254 & 20 & 169 & $12 B$ & 159 & 2053 & 105 & 3.03 & 13,66 & 17.56 & 14.24 & 4.94 \\
\hline GELATIN, PREPARED W/FRUIT & $2 \times 21 / 2$ & $\begin{array}{l}1 \\
1 \\
1\end{array}$ & 0 & $\begin{array}{r}409 \\
40\end{array}$ & 0.37 & 0.16 & 2.47 & 7 & 26.08 & 1.25 & 19.93 & 0.06 & $\begin{array}{l}4.74 \\
0.01\end{array}$ \\
\hline PEPPER STICKS & $1 / 8$ CUP & 18 & 0 & 0 & 0.55 & 0.14 & 2.71 & 19 & 27.55 & 0.27 & 1,98 & 0.06 & 0.00 \\
\hline CARROTS, MINI WHOLE & $\vdots 1 / 8$ CuP & $1: 9$ & 0 & 1 & 0.66 & 0.11 & 5.94 & 618 & 2.04 & 0.22 & 2.23 & 0.04 & 0.00 \\
\hline RANCH DRESSING CUPS & iserving & $1: 57$ & 0 & 80 & 0.00 & 0.00 & 0.00 & 0 & 0.00 & 0.00 & 0.32 & 6.40 & 0.96 \\
\hline YOGURT, FRESH, ASSORTED : & 402 & 1,114 & 6 & $B 2$ & 0.07 & 0.22 & 171.23 & 5 & 2.83 & 5.22 & 21.55 & 0.81 & 0.51 \\
\hline MARSHMALLOW KRISPIE SQUARES & $12 \times 21 / 4^{\circ}$ & 969 & 0 & 93 & 0.07 & 0.40 & 0.99 & 85 & 3.37 & 0.63 & 15.30 & 0.78 & $0.14 *$ \\
\hline JUICE CHOICE & 1402 & $1: 11$ & 0 & 5 & 0.06 & 0.24 & 9.17 & 5 & 16.02 & 0.45 & 17.85 & 0.13 & 0.03 \\
\hline MILK CHOICE - LUNCH & 1 CUP & $1: 169$ & 17 & 145 & 1.03 & 0.51 & 286.04 & 139 & 2.30 & 8.04 & 23,56 & 5.02 & 3.11 \\
\hline $\begin{array}{l}\text { FLY AYERAGE } \\
\text { OF CALORIES }\end{array}$ & & $1: 836$ & 54 & 925 & 4.13 & 3.40 & 499.17 & 967 & 83.25 & $\begin{array}{l}29.74 \\
14.24 x\end{array}$ & $\begin{array}{c}120.08 \\
57.44 \%\end{array}$ & $\begin{array}{l}27.54 \\
29.61 \%\end{array}$ & $\begin{array}{c}9.73 * \\
10.48 * *\end{array}$ \\
\hline
\end{tabular}




\begin{tabular}{|c|c|c|c|}
\hline $\begin{array}{l}\text { Page } 1 \\
\text { :=:=:= }\end{array}$ & 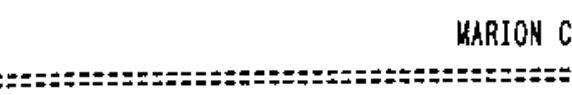 & COUNTY SCHOOLS & 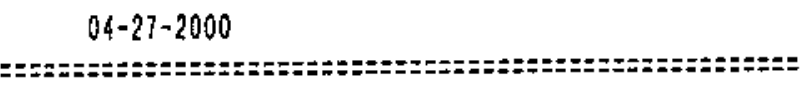 \\
\hline & $\begin{array}{l}\text { NUMEER OF PORTIONS: } 100 \\
\text { SIZE OF PORTIONS: } 3 / 4 \text { CUP }\end{array}$ & & $\begin{array}{l}B 8 \text { - CHICKEN POT PIE - HC } \\
\text { B-19 MOD }\end{array}$ \\
\hline & & & \\
\hline 020081 & FLOUR, ALL PURPOSE WHITE, ENRICHEO,BLEAC & 3 LBS & \\
\hline 002047 & SALT, TABLE....................... & $21 / 4 \mathrm{tsp}$ & \\
\hline 004587 & SHORTENING, BAKING, SOYBN(HYOR), PALM\&CTT & $1 L B+1102 S$ & ****PREPARE POURABLE RISCLIT BATIER FROM HIX IHSTEAO \\
\hline 014429 & 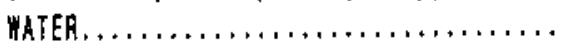 & $11 / 2$ CUP & 5 ib. bisucjt mix $=4$ stean table pans (100 servi \\
\hline 005013 & CHICKEN, MEAT, ROASTED, PULLED ......... & 9 LBS +9 OLS (ckd ngt, $e_{1}$ & \\
\hline 011583 & YEGETABLES, YIXED, FROZER, JNPREPAARED.... & 3 QTS $+21 / 4$ CUPS & FOLLOH DIRECTIOHS ON USDA D-19 \\
\hline 001001 & BUTTER,W/SALT...................... & 12025 & \\
\hline 011143 & CELERY, FRESH, RAH. ................ & $10 T+31 / 8$ CUPS (dicedi & MAY SUBSTITUTE TURKEY, BEEF, OR PORK FOR CHICKEN. \\
\hline 011284 & ONIONS, DEHYDRATEO FLAKES..$\ldots \ldots \ldots \ldots$ & $51 / 4025$ & \\
\hline 020081 & FLOUA, ALL PURPOSE WHITE, ENRICHED, BLEAC & $150 Z 3$ & \\
\hline 000084 & CHICKEH STOCK, .................... & $11 / 4$ GAL $+21 / 2$ CUPS & \\
\hline 002034 & POULTRY SEASONING ................... & $21 / 4$ tsp & \\
\hline 002030 & PEPPER, BLACK, $\ldots \ldots \ldots \ldots \ldots \ldots \ldots \ldots$ & $21 / 4 \operatorname{tsp}$ & \\
\hline
\end{tabular}




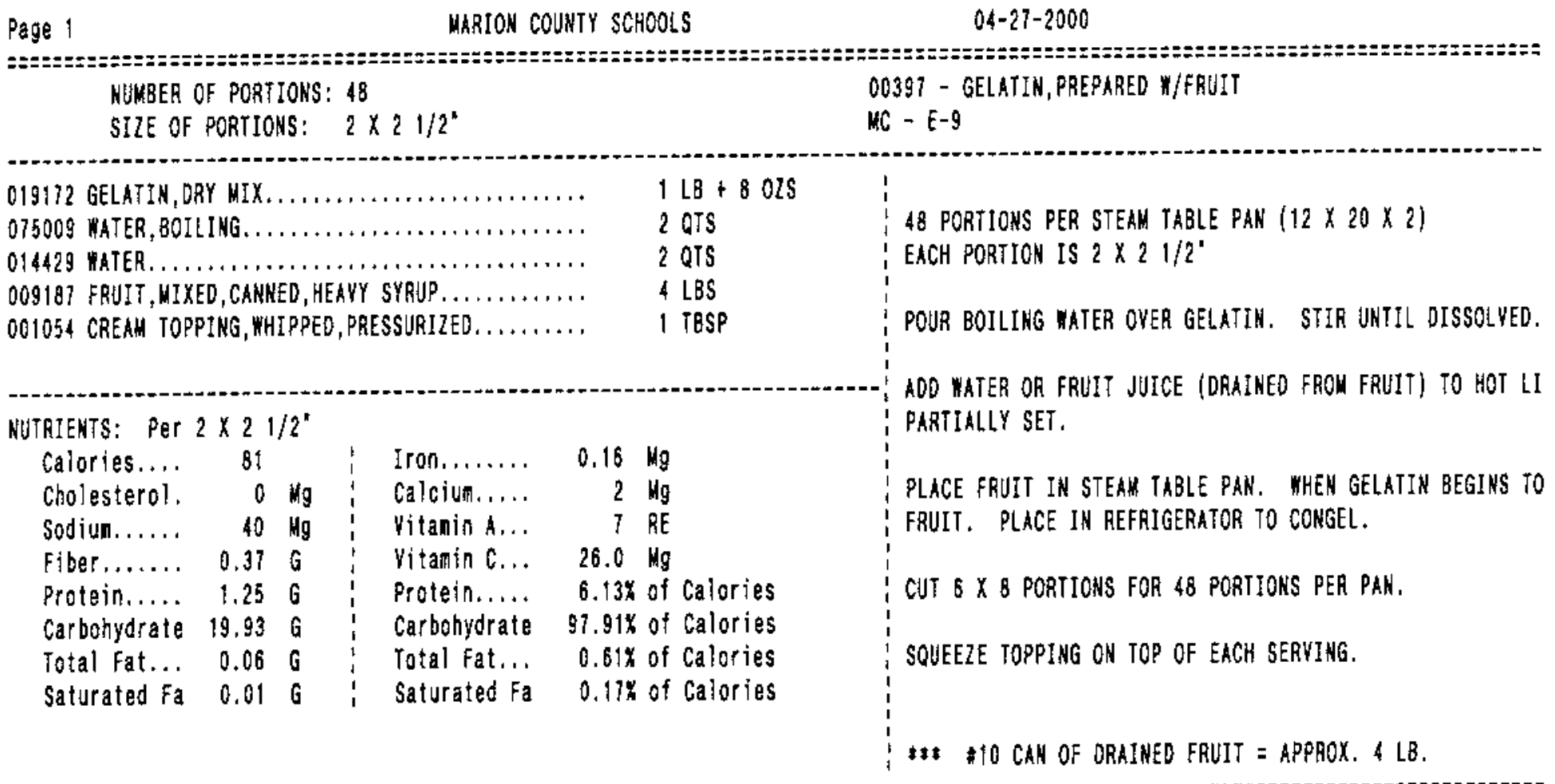




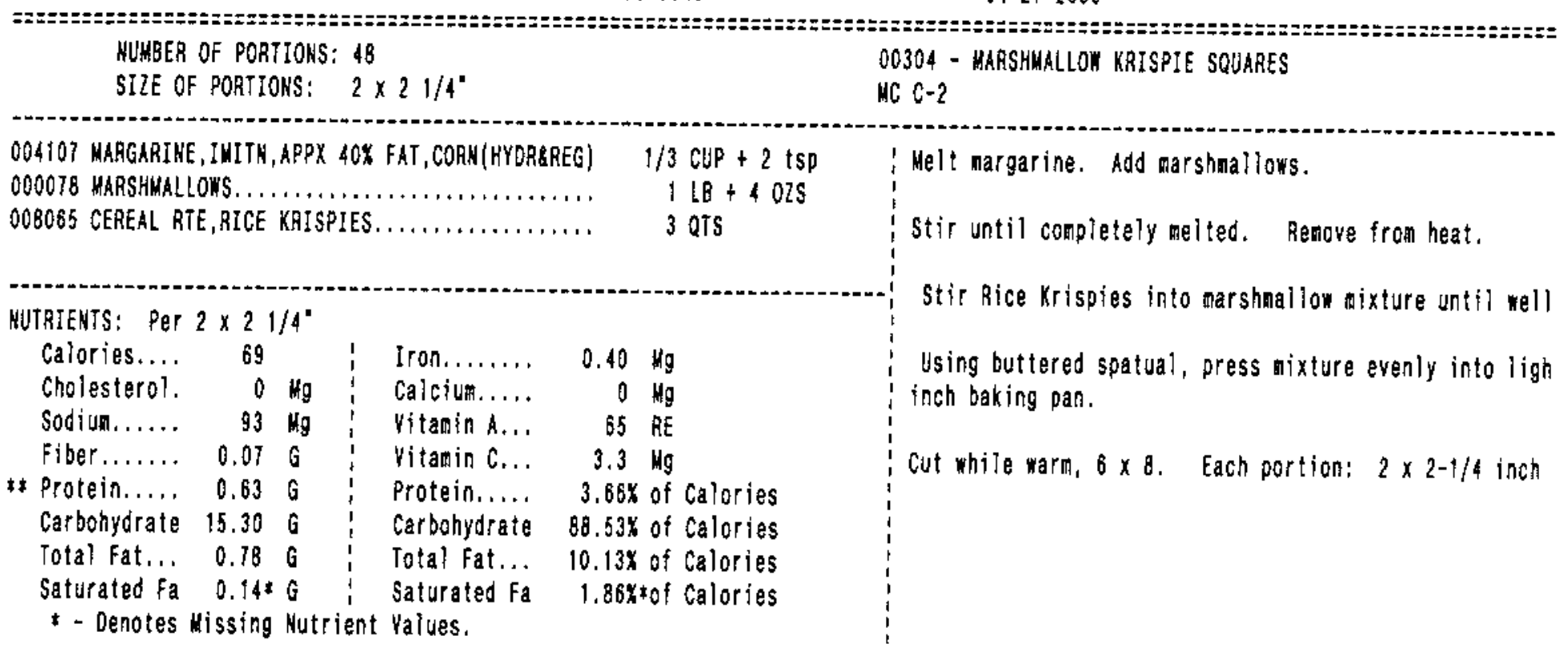


Page 1

$04 / 07 / 2000$ thre $04 / 07 / 2000$

\section{Recipe Name}

$$
\text { Portion iplan }
$$

Portion iplan, $\mathrm{Hg} \quad \mathrm{Hg} \quad \mathrm{G} \quad \mathrm{Hg}$

Hg RE Hg Całc Vit-k Vit-C
FRIOAY - 04/0T/2000

FISH STICKS

FRENCH FRIES: oven heat

KETCHUP: individual

SALAD, TOSSEO: no dressing

SALAD ORESSING, Assorted

CORHBREAD

WARGARINE

ICE CREAM

JUICE CHOICE

HILK CHOICE LUHCH

DAILY AVERAGE

* of calories

4 EACH
$1 / 2$ CUP
1 PC packet
$1 / 4$ CUP
OOz,
I EACH
IPAT
ICe Crean
1402.
11 CUP

$1: 18134$

1,559

$1: 60$

$1: 30$

$1) 880$

$11108 \quad 13$

1) $39 \quad 0$

$1,116 \quad 25$

1. 710

1) 169

$1,840 \quad 100$

* Denotes Nissing Nutrient Values

$\begin{array}{rrrrrrrrrr}226 & 0.00 & 0.40 & 0.00 * & 0 * & 0.00 & 15.88 & 14.76 & 5.68 & 0.00 \\ 11 & 0.10 & 0.26 & 0.00 * & 0 * & 3.86 & 0.66 & 8.67 & 1.84 & 0.001 \\ 71 & 0.07 & 0.04 & 1.14 & 6 & 0.90 & 0.09 & 1.64 & 0.02 & 0.00 \\ 2 & 0.28 & 0.09 & 3.83 & 37 & 2.70 & 0.20 & 0.70 & 0.04 & 0.00 \\ 140 & 0.06 & 0.14 & 21.08 & 3 & 0.33 & 0.55 & 3.03 & 8.45 & 1.33 \\ 950 & 0.91 & 0.93 & 69.27 & 20 & 0.18 & 2.71 & 18.08 & 2.75 & 0.16 \\ 39 & 0.00 & 0.00 & 0.00 & 0 & 0.00 & 0.00 & 0.00 & 4.35 & 0.85 \\ 46 & 0.00 & 0.05 & 74.24 & 87 & 0.34 & 2.03 & 13.69 & 6.38 & 3.93 \\ 5 & 0.06 & 0.24 & 9.17 & 5 & 16.02 & 0.45 & 17.65 & 0.13 & 0.03 \\ 145 & 1.03 & 0.51 & 286.04 & 139 & 2.30 & 8.04 & 23.56 & 5.02 & 3.11 \\ 839 & 3.15 & 2.69 & 464.79 & 281 & 26.66 & 30.61 & 101.78 & 34.68 & 0.141\end{array}$

$14.56 \% \quad 48.44 \%$ 37.08\% $10.43 \%$

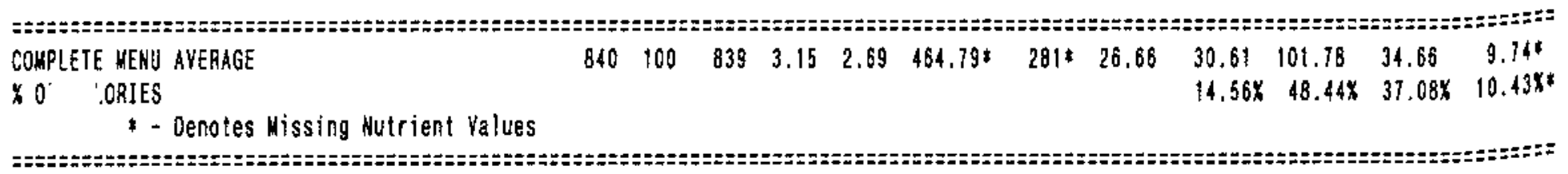


Page 1

$04 / 10 / 2000$ thru $04 / 20 / 2000$

\begin{tabular}{|c|c|c|c|c|c|c|c|c|c|c|c|c|c|}
\hline & $\begin{array}{l}\text { Portion } \\
\text { Size }\end{array}$ & $\begin{array}{l}\text { Plan } \\
\text { Oty }\end{array}$ & $\begin{array}{l}\text { Ng } \\
\text { chol }\end{array}$ & $\underset{\text { Sodn }}{\mathrm{Mg}}$ & $\begin{array}{c}G \\
\text { Fiber }\end{array}$ & $\begin{array}{l}\text { Mg } \\
\text { Iron }\end{array}$ & $\begin{array}{l}\text { Hg } \\
\text { Calc }\end{array}$ & $\begin{array}{c}\text { RE } \\
V i t-A\end{array}$ & $\underset{v i t-c}{H_{g}}$ & $\begin{array}{c}6 \\
\text { Prot }\end{array}$ & $\begin{array}{c}G \\
\text { Carb }\end{array}$ & $\begin{array}{c}G \\
\text { T-Fat }\end{array}$ & $\underset{S-F a t}{G}$ \\
\hline \multicolumn{14}{|l|}{ DNESOAY - 04/19/2000 } \\
\hline, 5 & .502 & $1: 41$ & 12 & 298 & 0.00 & 0.22 & 1,58 & 0 & 0.00 & 3.98 & 0.70 & 2.40 & 0.76 \\
\hline TATO CHEESE BAKE - Purchased & $1,1 / 2$ CUP & $1: 101$ & 4 & 512 & 1.20 & 0.30 & 5.30 & 11 & 5.20 & 2.49 & 97.00 & 2.80 & 1.40 \\
\hline PROTS, HINI WHOLE & $1 / 8$ CUP & 119 & 0 & $?$ & 0.66 & 0.11 & 5.94 & 618 & 2.04 & 0.22 & 2.23 & 0.04 & 0.00 \\
\hline KS & $1 / 8 \mathrm{CUP}$ & $1: 8$ & 0 & 0 & 0.55 & 0.14 & 2.77 & 19 & 27.55 & 0.27 & 1.98 & 0.06 & 0.00 \\
\hline NG CUPS & iserving & 1157 & 0 & 80 & 0.00 & 0.00 & 0.00 & 0 & 0.00 & 0.00 & 0.32 & 0.40 & 0.96 \\
\hline NEY & 202,1011 & $1: 126$ & 0 & 219 & 1.59 & 1.34 & 1.15 & $12 *$ & 1.13 & 4.16 & 25.03 & 1.20 & 0.20 \\
\hline & TPAT & 39 & 0 & 39 & 0.00 & 0.00 & 0.00 & 0 & 0.00 & 0.00 & 0.00 & 4.35 & 0.85 \\
\hline AKE & SLICE & $1: 210$ & 34 & 179 & 0.48 & 1.01 & 14.75 & 15 & 0.09 & 3.27 & 31.04 & 8.35 & 1.75 \\
\hline AM FROSTING & 2 TESP & 1,140 & 4 & 39 & 0.00 & 0.02 & 6.76 & 16 & 0.03 & 0.18 & 26.68 & 4.04 & 1.56 \\
\hline & 14 & $1: 71$ & 0 & 5 & 0.08 & 0.24 & 9.17 & 5 & 16.02 & 0.45 & 17.65 & 0.13 & 0.03 \\
\hline LK CHOICE - LUNCH & i cUP & $1: 169$ & 17 & 145 & 1.03 & 0.51 & 286.04 & 139 & 2.30 & 8.04 & 23.58 & 5.02 & 3.11 \\
\hline CALORIES & & 976 & 15 & 1528 & 5.58 & 3.81 & 399.49 & $840^{\circ}$ & 54.38 & $\begin{array}{c}23.06 \\
9.44 x\end{array}$ & $\begin{array}{c}146.19 \\
58.8 B \%\end{array}$ & $\begin{array}{l}34.79 \\
32.04 \%\end{array}$ & $\begin{array}{c}10.86 \\
9.83 \%\end{array}$ \\
\hline
\end{tabular}

* - Denotes Missing Hutrient Values

THURSDAY - 04/20/2000

\begin{tabular}{|c|c|c|c|c|c|c|c|c|c|c|c|c|c|}
\hline CHEESEBURGER ON A BUN & ! $\mathrm{EACH}$ & $\$ 396$ & 84 & 458 & 1.16 & 3.19 & 269.50 & 85 & 0.00 & 25.43 & 22.57 & 22.07 & 10.49 \\
\hline LET $\quad$ STOMATO:1 leaf,2 & $e_{1}^{i} 1$ if, 2 slci & $1: 7$ & 0 & 4 & 0.55 & 0.21 & 5.03 & 21 & 5.47 & 0.41 & 1.56 & 0.12 & 0.01 \\
\hline CONU ImEkTS & 'SERVING ! & 1122 & 0 & 208 & 0.23 & 0.21 & 5.22 & 1 & 1.00 & 0.34 & 5.43 & 0.27 & 0.01 \\
\hline QUICK BAKED POTATOES & I HALF-POT & 11173 & 0 & 79 & 3.42 & 1.96 & 14.57 & 11 & 18.27 & 3.27 & 35.62 & 2.35 & 0.40 \\
\hline GELATIN, PREPABED $\% / F R U I T$ & $12 \times 21 / 2+i$ & 1189 & 0 & 40 & 0.37 & 0.16 & 2.47 & 7 & 26.08 & 1.25 & 19.93 & 0.06 & 0.01 \\
\hline FRUIT,FRESH ASSORTED & :1/2 EACH & 35 & 0 & 0 & 9.33 & 0.12 & 8,43 & B & 8.59 & 0.36 & 9.14 & 0.18 & 0.03 \\
\hline JUICE CHOICE & 402 & 117 & 0 & 5 & 0.06 & 0.24 & 9.17 & 5 & 16.02 & 0.45 & 17.65 & 0.13 & 0.03 \\
\hline MILK CHOICE - LUNCH & 11 CUP & $1: 169$ & 17 & 145 & 1.03 & 0.51 & 286.04 & 139 & 2.30 & 8.04 & 23.56 & 5.02 & 3.11 \\
\hline AVERAGE & & 958 & 102 & 942 & 8.19 & 8.63 & 600.45 & 287 & 11.76 & $\begin{array}{l}39.55 \\
16.52 \mathrm{x}\end{array}$ & $\begin{array}{c}\$ 35.46 \\
58.52 \%\end{array}$ & $\begin{array}{l}30.20 \\
28.35 x\end{array}$ & $\begin{array}{l}14.13 \\
13.27\end{array}$ \\
\hline
\end{tabular}




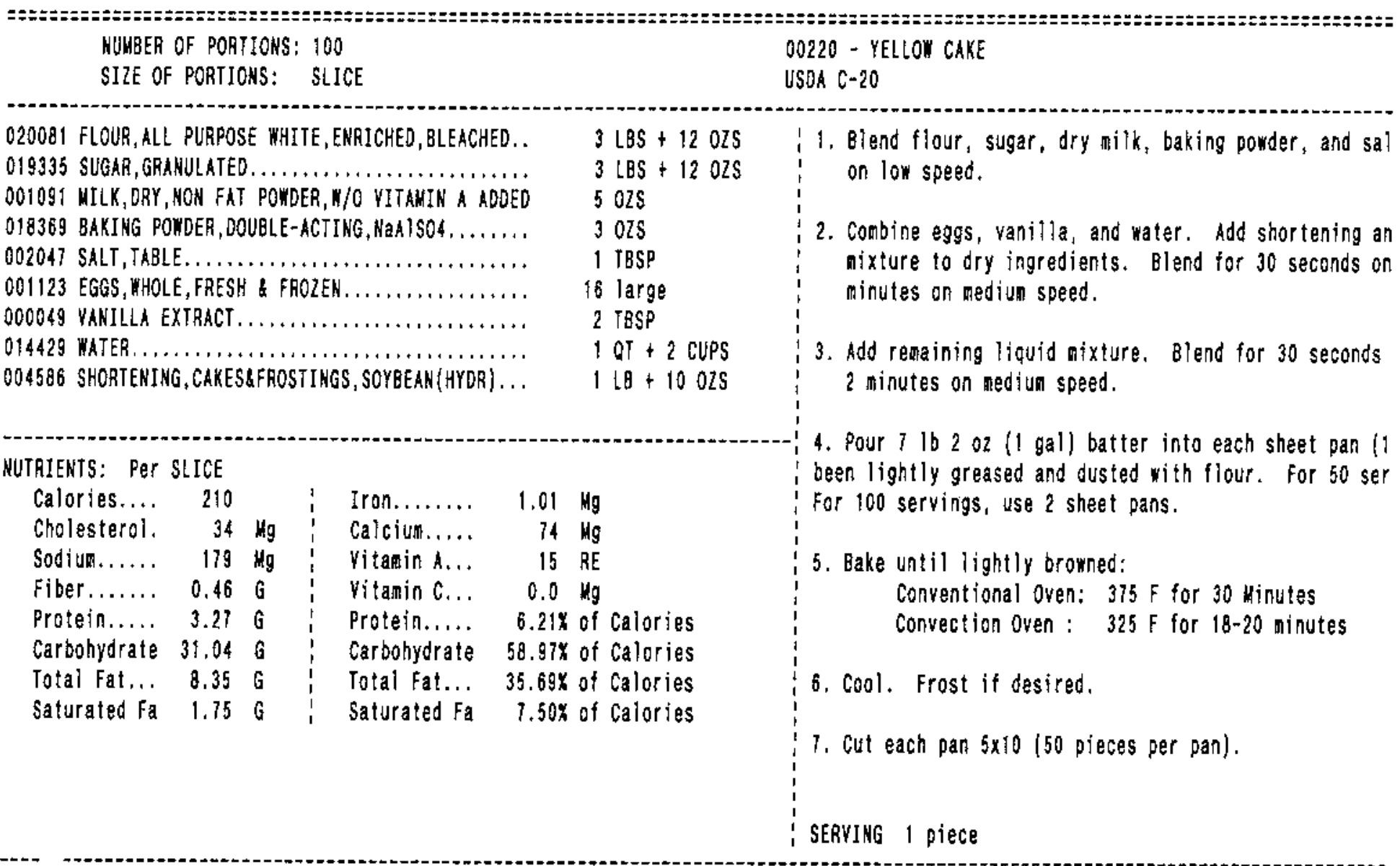




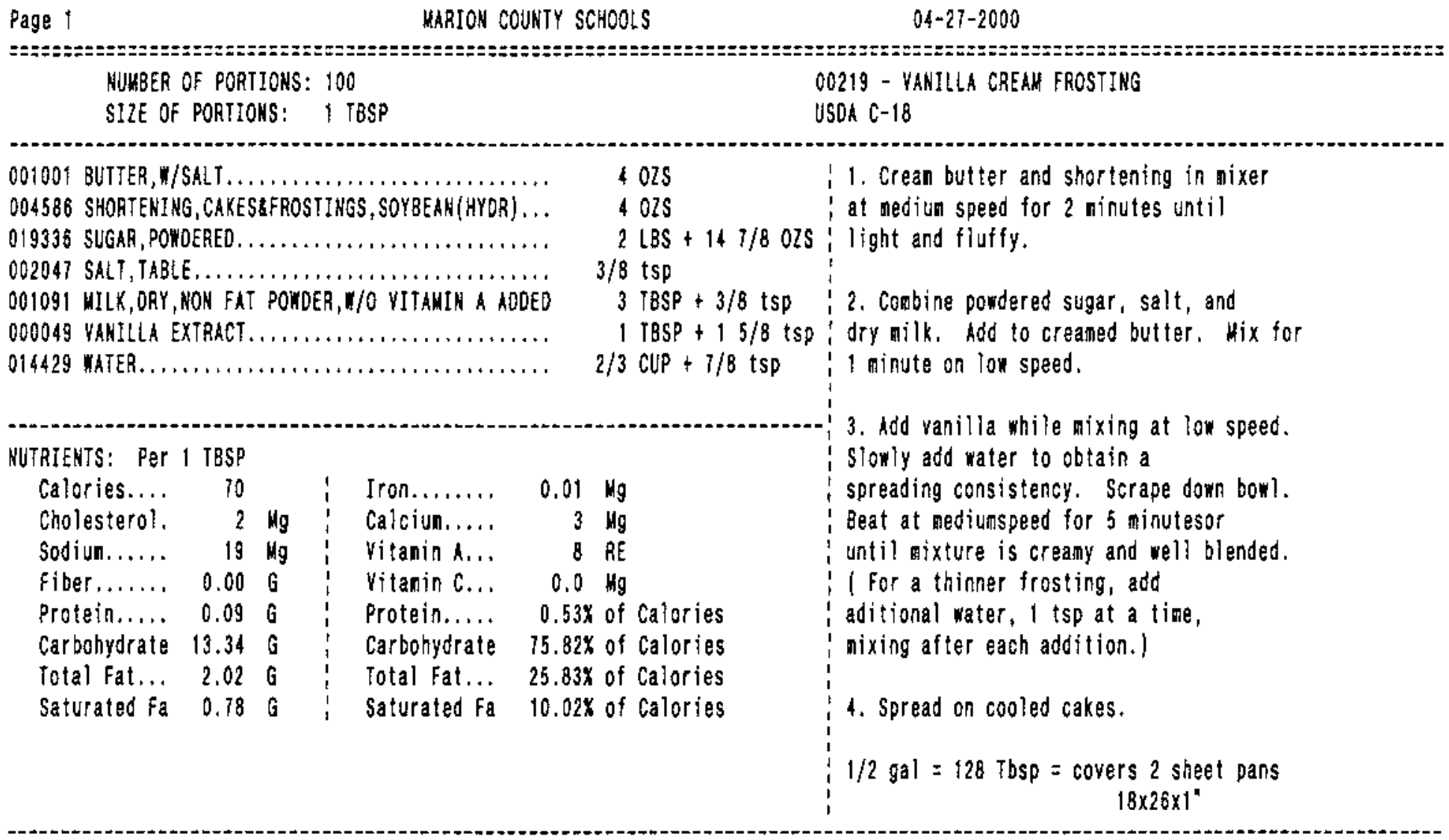




\section{Plif Menu Report}

Menu: Menu1-mod

Total Davs: 1

Total Foods: 8

Ava. Dailv Cals: 694.00

\begin{tabular}{|c|c|c|c|c|c|c|c|}
\hline Day & Meal & Food & Amt'Portion & Kcal & Protein & Carb & Fat \\
\hline \multirow[t]{9}{*}{ Day 1} & & & & 693.716 & 34.150 & 73.352 & 30.102 \\
\hline & & 25257 Meat Loaf & 1.000 SERVING & 232.837 & 17.308 & 8.429 & 14.144 \\
\hline & & $\begin{array}{l}653 \text { Mashed Potatoes, } \\
\text { Prepared from Dehydrated } \\
\text { Gran }\end{array}$ & 0.500 CUP & 82.537 & 2.090 & 13.687 & 2.299 \\
\hline & & 25290 Brown Grawy & $1.000 \mathrm{FL} \mathrm{OZ}$ & 24.271 & 0.957 & 1.946 & 1.406 \\
\hline & & 8691 Baby Carrots & $6.000 \mathrm{ITEM}$ & 22.800 & 0.504 & 4.896 & 0.318 \\
\hline & & 25020 Whole Wheat Rolls & 2.000 OUNCE & 155.388 & 4.883 & 25.792 & 3.968 \\
\hline & & $\begin{array}{l}114 \text { Margarine, with } \\
\text { Unspecified Oils }\end{array}$ & 4.000 GRAM & 28.748 & 0.036 & 0.036 & 3.220 \\
\hline & & $\begin{array}{l}3042 \text { Peaches, Canned in } \\
\text { Extra Light Syrup }\end{array}$ & $0.250 \mathrm{CUP}$ & 25.935 & 0.247 & 6.854 & 0.062 \\
\hline & & 51 Reduced Fat Milk, $2 \%$ & 1.000 CUP & 121.200 & 8.125 & 11.712 & 4.685 \\
\hline
\end{tabular}




\section{Pli Menu Report}

Menu: Menu2-mod

Total Davs: 1

Total Foods: 10

Avg. Dailv Cals: 723.00

\begin{tabular}{|c|c|c|c|c|c|c|c|}
\hline Day & Meal & Food & AmtiPortion & Kcal & Protein & Carb & Fat \\
\hline \multirow[t]{11}{*}{ Day 1} & & & & 722.501 & 31.021 & 82.739 & 30.809 \\
\hline & & 432 Saltine Crackers & 4.000 ITEM & 52.080 & 1.104 & 8.580 & 1.416 \\
\hline & & $\begin{array}{l}8467 \text { Carrots, Cut Top. } \\
\text { Scraped }\end{array}$ & 0.125 CUP & 6.839 & 0.140 & 1.469 & 0.040 \\
\hline & & 8453 Celery, Trimmed & 0.125 CUP & 2.748 & $0 . \dagger 27$ & 0.517 & 0.024 \\
\hline & & $\begin{array}{l}114 \text { Margarine, with } \\
\text { Unspecified Oils }\end{array}$ & 4.000 GRAM & 28.748 & 0.036 & 0.036 & 3.220 \\
\hline & & 223 Apple & 0.500 ITEM & 40.710 & 0.131 & 10.523 & 0.248 \\
\hline & & $\begin{array}{l}14717 \text { DANNON Low Fat } \\
\text { Raspberry Yogurt }\end{array}$ & 4.000 OUNCE & 119.894 & 4.496 & 22.480 & 1,499 \\
\hline & & 51 Reduced Fat Milk, $2 \%$ & 1.000 CUP & 121.200 & 8.125 & 11.712 & 4.685 \\
\hline & & $\begin{array}{l}1 \text { Chill Con Carne with } \\
\text { Beans-mod }\end{array}$ & $0.500 \mathrm{CUP}$ & 204.815 & 14.566 & 11.231 & 11.624 \\
\hline & & $\begin{array}{l}8577 \text { Combread, Prepared } \\
\text { with } 2 \% \text { Lowfat Milk }\end{array}$ & 0.500 PIECE & 86.450 & 2.178 & 14.137 & 2.307 \\
\hline & & $\begin{array}{l}3666 \text { Reduced Calorie } \\
\text { Ranch Salad Dressing }\end{array}$ & 1.000 OUNCE & 59.017 & 0.119 & 2.054 & 5.746 \\
\hline
\end{tabular}




\section{PYI Menu Report}

Menu: Menu3-mod

Total Davs: 1

Total Foods: $\quad 9$

Ava. Dailv Cals: 766.00

\begin{tabular}{|c|c|c|c|c|c|c|c|}
\hline Day & Meal & Food & Amt/Portion & Kcal & Protein & Carb & Fat \\
\hline \multirow[t]{10}{*}{ Day 1} & & & & 766.459 & 31.796 & $82.87 \uparrow$ & 34,462 \\
\hline & & $\begin{array}{l}8467 \text { Carrots, Cut Top, } \\
\text { Scraped }\end{array}$ & 0.125 CUP & 6.839 & 0.140 & 1.469 & 0.040 \\
\hline & & 8448 Bell or Sweet Pepper & 0.125 CUP & 2.695 & 0.170 & 0.590 & 0.023 \\
\hline & & $\begin{array}{l}114 \text { Margarine, with } \\
\text { Unspecified Oils }\end{array}$ & 4.000 GRAM & 28.748 & 0.036 & 0.036 & 3.220 \\
\hline & & 51 Reduced Fat Milk, $2 \%$ & 1.000 CUP & 121.200 & 8.125 & 11.712 & 4.685 \\
\hline & & 223 Apple & 0.500 ITEM & 40.710 & 0.131 & 10.523 & 0.248 \\
\hline & & $\begin{array}{l}1467 \text { Chicken, Dark Meat } \\
\text { and Skin, Breaded, Fried }\end{array}$ & 3.000 OUNCE & 247.350 & 17.272 & 9.019 & 15.334 \\
\hline & & 30280 Rice Pilaf & 0.500 CUP & 129.478 & 2.163 & 22.161 & 3,410 \\
\hline & & 2 Honey Wheat Rolls-mod & 2.000 OUNCE & 130.422 & 3.640 & 25.307 & 1.756 \\
\hline & & $\begin{array}{l}3666 \text { Reduced Calorie } \\
\text { Ranch Salad Dressing }\end{array}$ & 1.000 OUNCE & 59.017 & 0.119 & 2.054 & 5.746 \\
\hline
\end{tabular}




\section{PII Menu Report}

Menu: Menu4-mod

Total Days: 1

Total Foods: 8

Ava. Dailv Cals: 764.00

\begin{tabular}{|c|c|c|c|c|c|c|c|}
\hline Day & Meal & Food & Amt/Portion & Kcal & Protein & Carb & Fat \\
\hline \multirow[t]{9}{*}{ Day 1} & & & & 764.114 & 37.968 & 101.418 & 23.912 \\
\hline & & 3 Chicken Pot Pie-mod & 1.000 SERVING & 298.216 & 22.252 & 27.796 & 10.362 \\
\hline & & 4 Gelatin, prepared w/fruit & 1.000 SERVING & 81.601 & 1.253 & 19.976 & 0.027 \\
\hline & & 8448 Bell or Sweet Pepper & 0.125 CUP & 2.695 & 0.170 & 0.590 & 0.023 \\
\hline & & $\begin{array}{l}8467 \text { Carrots, Cut Top, } \\
\text { Scraped }\end{array}$ & 0.125 CUP & 6.839 & 0.140 & 1.469 & 0.040 \\
\hline & & $\begin{array}{l}3666 \text { Reduced Calorie } \\
\text { Ranch Salad Dressing }\end{array}$ & $1.000 \mathrm{OUNCE}$ & 59.017 & 0.119 & 2,054 & 5.746 \\
\hline & & $\begin{array}{l}14715 \text { DANNON Low Fat } \\
\text { Mixed Berries Yogurt }\end{array}$ & 113.000 GRAM & 119.471 & 4.480 & 22.401 & 1.493 \\
\hline & & $\begin{array}{l}6 \text { Marshmallow Krispie } \\
\text { Squares-mod }\end{array}$ & 1.000 SERVING & 75.075 & 0.629 & 15.420 & 1.537 \\
\hline & & 51 Reduced Fat Milk, $2 \%$ & 1.000 CUP & 121.200 & 8.125 & 11.712 & 4.685 \\
\hline
\end{tabular}




\section{Pli Menu Report}

Menu: Menu5-mod

Total Davs: 1

Total Foods: 9

Ava. Dailv Cals: 689.00

\begin{tabular}{|c|c|c|c|c|c|c|c|}
\hline Day & Meal & Food & Amt/Portion & Kcal & Protein & Carb & Fat \\
\hline \multirow[t]{10}{*}{ Day 1} & & & & 688.755 & 22.801 & 74.350 & 33.767 \\
\hline & & $\begin{array}{l}7201 \text { HUNT'S Ketchup } \\
\text { Packets (FS) }\end{array}$ & 1.000 ITEM & 9.590 & 0.220 & 2.220 & 0.050 \\
\hline & & $\begin{array}{l}29591 \text { Lettuce Salad with } \\
\text { Tomatoes and/or Carrots, }\end{array}$ & $0.250 \mathrm{CUP}$ & 3.267 & 0.169 & 0.680 & 0.044 \\
\hline & & $\begin{array}{l}114 \text { Margarine, with } \\
\text { Unspecified Oils }\end{array}$ & 4.000 GRAM & 28.748 & 0.036 & 0.036 & 3.220 \\
\hline & & 51 Reduced Fat Milk, $2 \%$ & 1.000 CUP & 121.200 & 8.125 & 11.712 & 4.685 \\
\hline & & $\begin{array}{l}\text { 10914 GORTONS Fish } \\
\text { Sticks }\end{array}$ & 4.000 ITEM & 176.000 & 8.800 & 20.000 & 6.400 \\
\hline & & $\begin{array}{l}29255 \text { French Fried } \\
\text { Potatoes, Frozen }\end{array}$ & 6.000 ITEM & 60.840 & 0.963 & 9.488 & 2.301 \\
\hline & & $\begin{array}{l}29335 \text { GOOD SEASONS } \\
\text { italian Salad Dressing Mix, } \\
\text { Pre }\end{array}$ & $1.000 \mathrm{TBSP}$ & 70.000 & 0.000 & 0.500 & 7.500 \\
\hline & & $\begin{array}{l}8577 \text { Combread, Prepared } \\
\text { with } 2 \% \text { Lowfat Milk }\end{array}$ & 0.500 PIECE & 86.450 & 2.178 & 14.137 & 2.307 \\
\hline & & $\begin{array}{l}76 \text { Vanilla lce Cream, } \\
\text { Approximately } 10 \% \text { Fat }\end{array}$ & $4.000 \mathrm{FL} \mathrm{OZ}$ & 132.660 & 2.340 & 15.576 & 7.260 \\
\hline
\end{tabular}




\section{Plf Menu Report}

Menu: Menu6-mod

Total Davs: $\quad 1$

Total Foods: 9

Avg. Daily Cals: 759.00

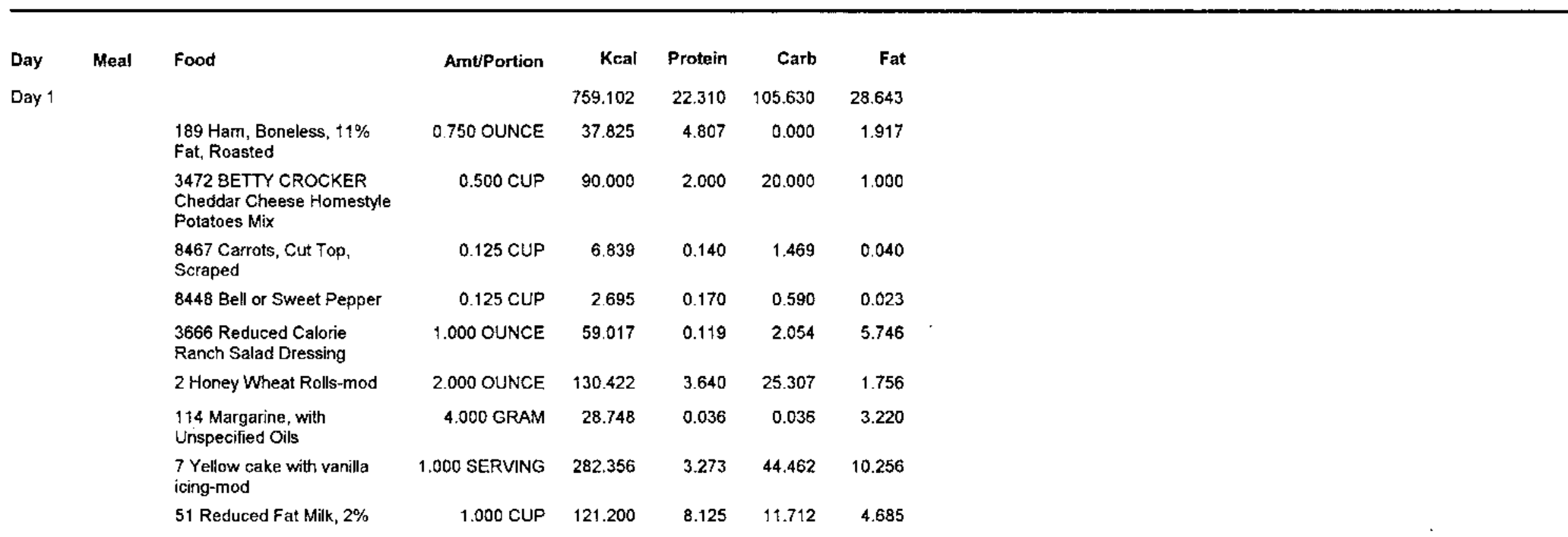




\section{Pli Menu Report}

Menu: menu7-mod

Total Days: 1

Total Foods: 10

Ava. Daily Cals: 871.00

\begin{tabular}{|c|c|c|c|c|c|c|c|}
\hline Day & Meal & Food & Ant/Portion & Kcal & Protein & Carb & Fat \\
\hline \multirow[t]{11}{*}{ Day 1} & & & & 871.243 & 40.663 & 80.646 & 42.845 \\
\hline & & $\begin{array}{l}489 \text { Plain Hamburger } \\
\text { Rolf/Bun }\end{array}$ & 1.000 ITEM & 122.980 & 3.655 & 21.629 & 2.193 \\
\hline & & $\begin{array}{l}165 \text { Ground Beef Patty, } \\
\text { Lean, Broiled Medium }\end{array}$ & 3.000 OUNCE & 231.200 & 21.012 & 0.000 & 15.691 \\
\hline & & $\begin{array}{l}9128 \text { KRAFT Singles } \\
\text { Pasteurized Process } \\
\text { American Ch }\end{array}$ & 1.000 SLICE & 110.000 & 6.000 & 3.000 & 8.000 \\
\hline & & $\begin{array}{l}8467 \text { Carrots, Cut Top. } \\
\text { Scraped }\end{array}$ & $0.250 \mathrm{CUP}$ & 13.678 & 0.280 & 2.938 & 0.080 \\
\hline & & 223 Apple & 1.000 ITEM & 81.420 & 0.262 & 21.045 & 0.497 \\
\hline & & $\begin{array}{l}7325 \text { KEEBLER Honey } \\
\text { Graham Crackers (FS) }\end{array}$ & 3.000 ITEM & 89.961 & 0.999 & 17.992 & 2.000 \\
\hline & & 51 Reduced Fat Milk, $2 \%$ & $1.000 \mathrm{CUP}$ & 121.200 & 8.125 & $11.7 \uparrow 2$ & 4.685 \\
\hline & & $\begin{array}{l}7201 \text { HUNT'S Ketchup } \\
\text { Packets (FS) }\end{array}$ & 1.000 ITEM & 9.590 & 0.220 & 2.220 & 0.050 \\
\hline & & .700 Yellow Mustard & 5.500 GRAM & 5.500 & 0.110 & 0.110 & 0.220 \\
\hline & & $\begin{array}{l}14616 \text { HELLMAN'S Real } \\
\text { Mayonnaise }\end{array}$ & 12.000 GRAM & 85.714 & 0.000 & 0.000 & 9.429 \\
\hline
\end{tabular}

